INVESTIGATING E-SERVICESCAPE, TRUST, E-WOM, AND CUSTOMER LOYALTY

Gina A. Tran, B.A., B.S., M.S.

Dissertation Prepared for the Degree of

DOCTOR OF PHILOSOPHY

UNIVERSITY OF NORTH TEXAS

August 2014

\title{
APPROVED:
}

David Strutton, Major Professor

Kenneth Thompson, Committee Member

Francisco Guzmán, Committee Member

Robert Pavur, Committee Member

Charles Blankson, PhD Program Coordinator

Jeff Sager, Chair of the Department of

Marketing and Logistics

O. Finley Graves, Dean of the College of Business

Mark Wardell, Dean of the Toulouse Graduate School 
Tran, Gina A. Investigating E-Servicescape, Trust, E-WOM, and Customer Loyalty. Doctor of Philosophy (Marketing), August 2014, 112 pp., 27 tables, 5 figures, references, 278 titles.

Old Spice cleverly used a handsome actor to play the Old Spice Man character for a Super Bowl commercial in 2010. After the game, this Old Spice commercial was viewed more than 13 million times on YouTube, a social media video-sharing site. This viral marketing campaign, also known as electronic word-of-mouth (E-WOM), propelled the Old Spice brand into the forefront of consumers' minds, increased brand awareness, and inspired people to share the video links with their family, friends, and co-workers.

The rapid growth of E-WOM is an indication of consumers' increased willingness to convey marketing messages to others. However, despite this development, marketing academics and practitioners do not fully understand this powerful form of marketing. This dissertation enriches our understanding of E-WOM and how e-servicescape may lead to E-WOM. To that end, stimulus-organism-response theory and the network co-production model of E-WOM are applied to investigate the relationships between e-servicescape, trust, E-WOM intentions, customer loyalty, and purchase intentions. Two forms of E-WOM were examined, namely emails and social network postings. E-servicescape is defined as the online environmental factors of a marketer's website. E-servicescape is composed of three main dimensions, including aesthetic appeal, financial security, and layout and functionality.

This study used cross-sectional customer data from a single e-tailer. Structural equation modeling was used to analyze the responses. Customer reviews was added as an additional subdimension of e-servicescape. The findings suggest e-servicescape positively impacts trust, which in turn positively influences E-WOM and customer loyalty. Moreover, two groups of customers 
were compared using multi-group analysis, where one group of users received emails and the other group received social network postings from the same e-tailer. Overall, the results indicated emails had a stronger impact on e-servicescape, E-WOM, and customer loyalty. Social networking site postings had slightly greater influence on trust, and two sub-dimensions of eservicescape, i.e., interactivity and ease of payment.

These findings contribute to the marketing research on E-WOM theory and electronic commerce shopping behavior. In particular, the sub-dimension of customer reviews is added to e-servicescape. This study yields practical implications for marketers in understanding consumers' perceptions of websites and how to better design sites. In addition, these findings add to knowledge on how to engender consumers' trust and customer loyalty online. Finally, this research provides suggestions for firms wanting to create marketing campaigns that will lead to E-WOM. 


\section{Copyright 2014}

\section{By}

Gina A. Tran 


\section{ACKNOWLEDGEMENTS}

My research, along with my Ph.D., would not be possible without the encouragement and mentorship of many people. Although my name is on the degree, I am grateful to many who have helped me through the years. I appreciate the guidance and support of my professors, colleagues, family, and friends throughout this journey.

I am grateful to my major professor, Dr. David Strutton, for his support, advice, and help during my years in the Ph.D. program. I would like to also thank my dissertation committee members, Dr. Kenneth Thompson, Dr. Francisco Guzmán, and Dr. Robert Pavur, for their patience and guidance. My research would not be possible without Mrs. Bonnie Strutton, and I would like to thank her for her assistance with my research data. I also thank Dr. Charles Blankson for his optimism and mentorship during my first year in the program.

A big thank you to my family and friends, who have listened to me, encouraged me, and served as my research subjects. I appreciate their support, friendship, and help as I struggled through the program. I dedicate my dissertation to my grandparents, Thach and The Nguyen, for supporting me, believing in me, and passing on the love of learning to me. Last, but not least, I thank Rashad and Bobbie Bella, for cheering me on, keeping me company, and loving me. I thank God for these blessings in my life. 


\section{TABLE OF CONTENTS}

Page

ACKNOWLEDGEMENTS .iii

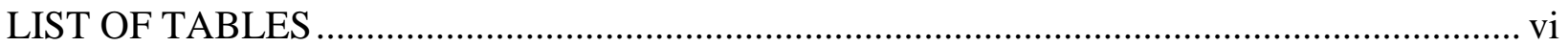

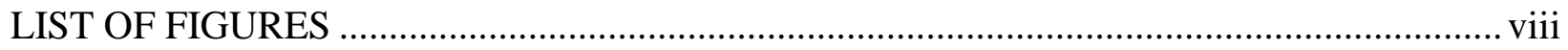

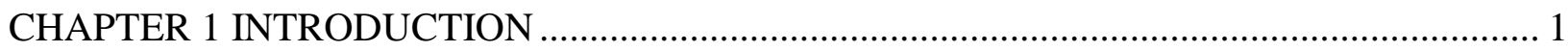

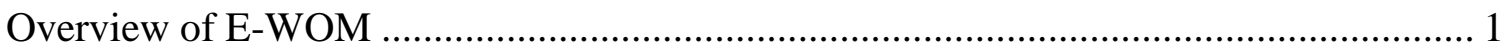

Overview of E-Servicescape, Trust, Purchase Intentions, and Loyalty ............................. 3

Overview of Email and Social Networking Sites ........................................................ 5

Theoretical Framework and Research Questions ..................................................... 6

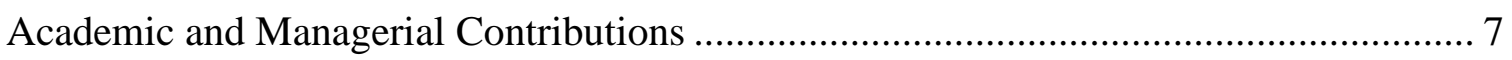

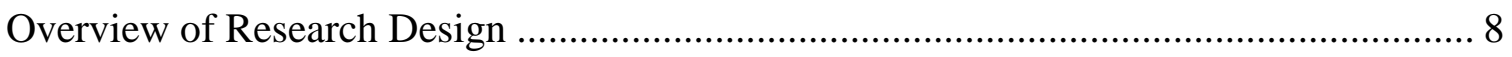

CHAPTER 2 LITERATURE REVIEW, THEORETICAL BACKGROUND, AND

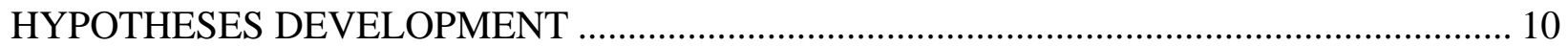

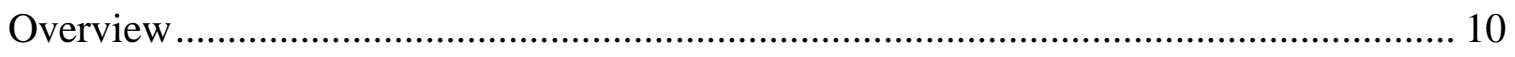

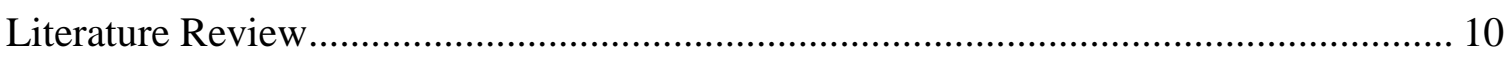

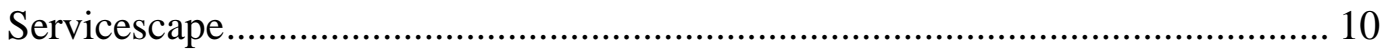

Expanding the Servicescape Framework ........................................................ 12

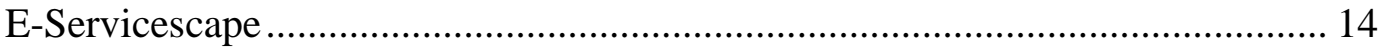

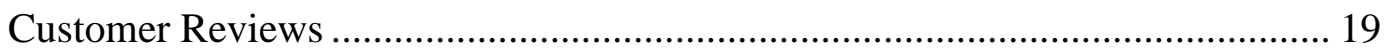

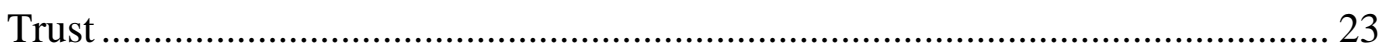

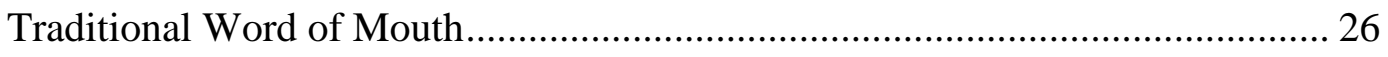

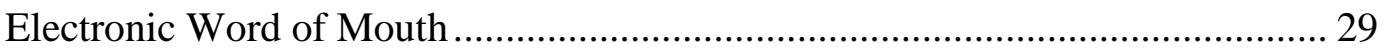

Interactive Electronic Word of Mouth Campaigns ............................................. 32

Motivations to Engage in Electronic Word of Mouth ......................................... 33

Email Marketing and Electronic Word of Mouth ............................................ 33

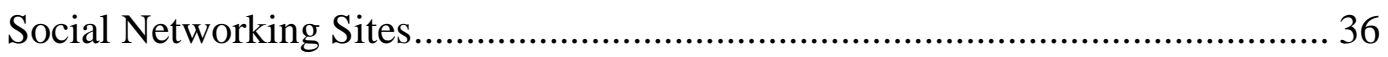

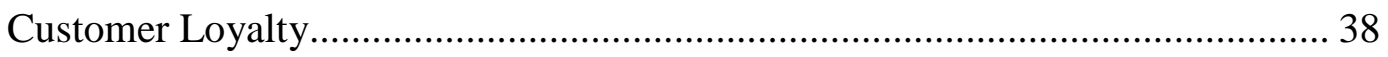

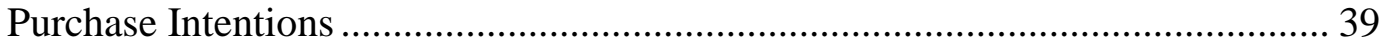

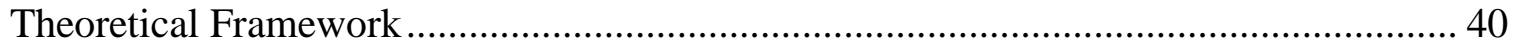

Commitment-Trust Theory of Relationship Marketing..................................... 40 
Socialization Theory …………………………………............................... 41

Stimulus-Organism-Response (SOR) Theory......................................................... 42

Organic Inter-Consumer Influence Model (OIIM) ............................................... 43

Linear Marketer Influence Model (LMIM) ........................................................ 43

Network Co-Production Model (NCPM)............................................................... 44

Model and Hypotheses Development .............................................................................. 45

CHAPTER 3 METHODOLOGY ………....................................................................... 49

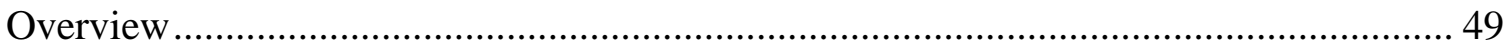

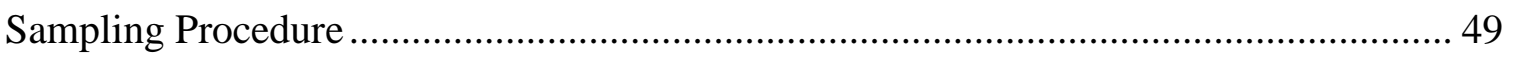

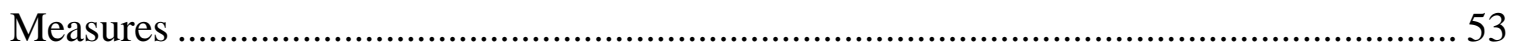

Aesthetic Appeal ......................................................................................... 53

Layout and Functionality .............................................................................. 54

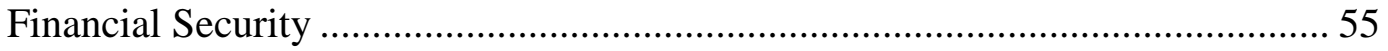

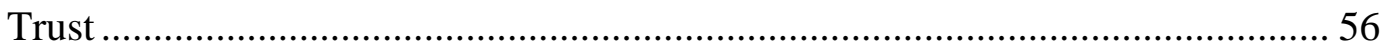

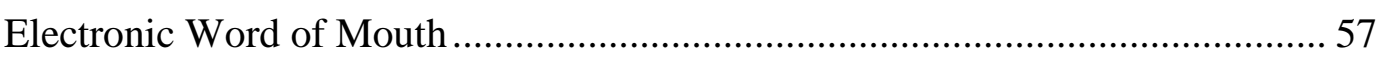

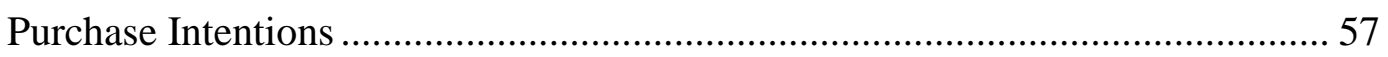

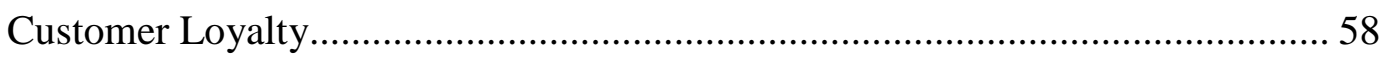

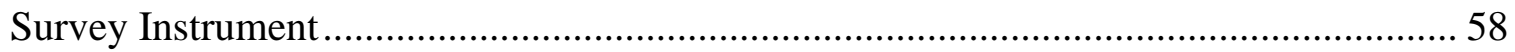

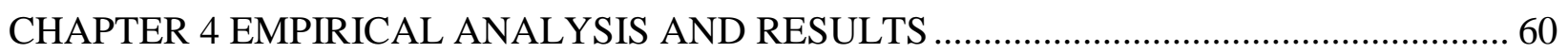

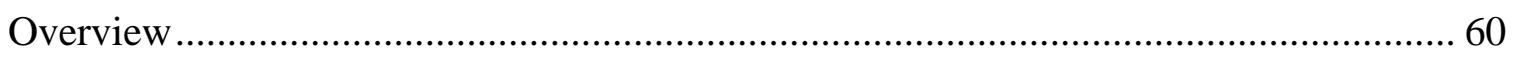

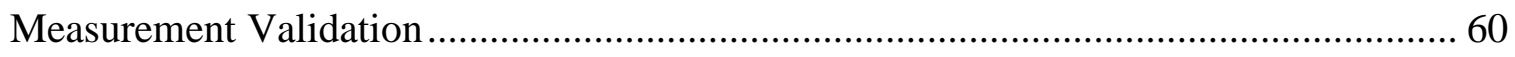

Testing for Common Method Bias …………………………………………………….. 75

Hypotheses Testing ......................................................................................................... 75

Hypotheses Testing: Multi-Group Analysis ...................................................................... 79

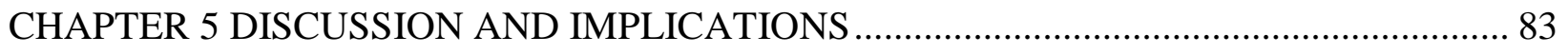

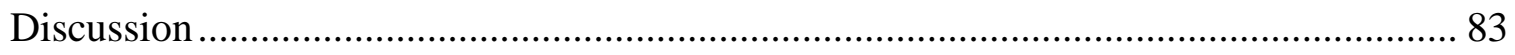

Theoretical Contributions ………………………………............................................ 84

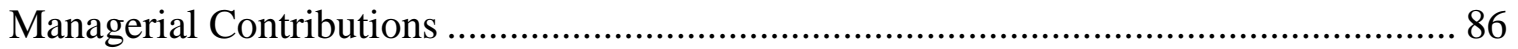

Limitations and Future Research ................................................................................... 91

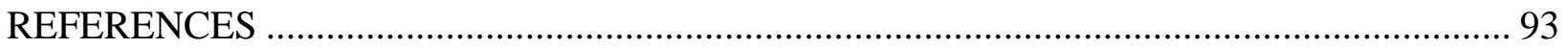




\section{LIST OF TABLES}

Page

TABLE 1: Demographic Profile of Respondents ………..................................................... 50

TABLE 2: Comparison of Early and Late Respondents on Demographic Variables.................... 52

TABLE 3: Comparison of Early and Late Respondents on Key Constructs................................. 53

TABLE 4: Items for Aesthetic Appeal Dimension of E-Servicescape............................................ 54

TABLE 5: Items for Layout and Functionality Dimension of E-Servicescape .............................. 55

TABLE 6: Items for Financial Security Dimension of E-Servicescape ……………….................. 56

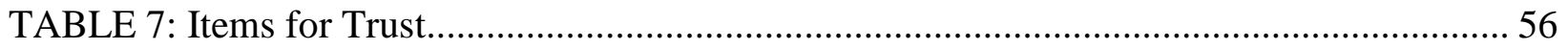

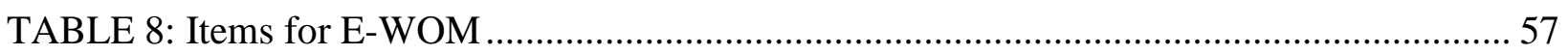

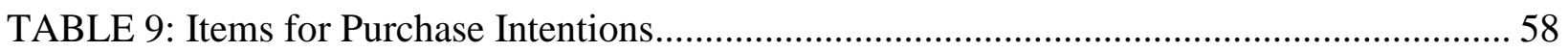

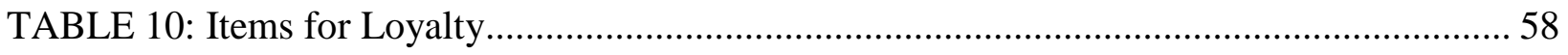

TABLE 11: Measurement Model Evaluation: Initial EFA for E-Servicescape ............................... 61

TABLE 12: Measurement Model Evaluation: Initial EFA for Trust, E-WOM Intentions,

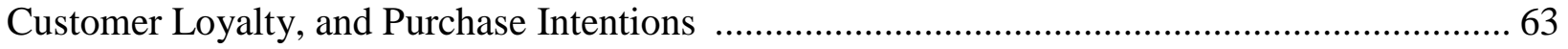

TABLE 13: First Iteration, Correlations and Discriminant Validity for E-Servicescape............... 65

TABLE 14: Second Iteration, Correlations and Discriminant Validity for E-Servicescape ......... 66

TABLE 15: Third Iteration, Correlations and Discriminant Validity for E-Servicescape ............ 67

TABLE 16: Fourth Iteration, Correlations and Discriminant Validity for E-Servicescape .......... 68

TABLE 17: Fifth Iteration, Correlations and Discriminant Validity for E-Servicescape ............. 69

TABLE 18: Sixth Iteration, Correlations and Discriminant Validity for E-Servicescape............. 69

TABLE 19: Seventh Iteration, Correlations and Discriminant Validity for E-Servicescape ........ 70

TABLE 20: First Iteration, Correlations and Discriminant Validity for Mediator and Endogenous Variables (Trust, E-WOM Intentions, Customer Loyalty, and Purchase Intentions)................... 71

TABLE 21: Second Iteration, Correlations and Discriminant Validity for Mediator and Endogenous Variables (Trust, E-WOM Intentions, and Customer Loyalty). 
TABLE 22: Third Iteration, Correlations and Discriminant Validity for Mediator and Endogenous Variables (Trust, E-WOM Intentions, and Customer Loyalty)............................. 72

TABLE 23: Fourth Iteration, Correlations and Discriminant Validity for Mediator and Endogenous Variables (Trust, E-WOM Intentions, and Customer Loyalty)............................. 73

TABLE 24: Final Measurement Items for All Variables........................................................ 73

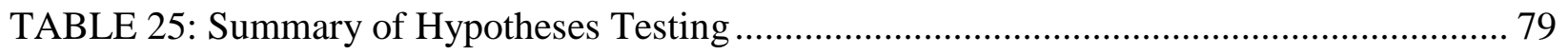

TABLE 26: Comparing Two Groups Using BIC .............................................................. 80

TABLE 27: Summary of Hypotheses Testing, Multi-Group Analysis....................................... 82 


\section{LIST OF FIGURES}

Page

FIGURE 1 Stimulus-Organism-Response Model............................................................ 43

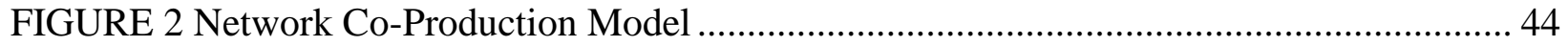

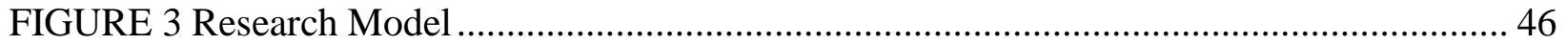

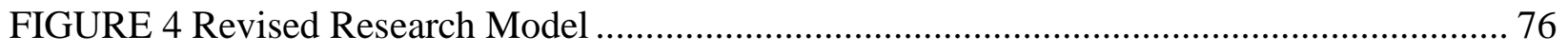

FIGURE 5 Research Model with Path Estimates for Full Sample ............................................. 78 


\section{CHAPTER 1}

\section{INTRODUCTION}

To promote the Old Spice brand, a short, a 30-second commercial was aired during the Super Bowl in 2010. Handsome actor Isaiah Mustafa played the Old Spice Man; his character cheekily assured women that he was "the man your man could smell like.” After the game, this Old Spice commercial was uploaded on the social media video-sharing site YouTube and was viewed more than 13 million times. To further extend the life of this marketing campaign theme, the company later posted messages on Facebook and Twitter inviting users to ask the Old Spice Man questions about manliness. In almost real time, short video vignettes featuring the Old Spice Man’s responses to users' queries were posted. Over the course of two days, more than 180 video responses were posted. More importantly, these video clips were viewed over 23 million times in 36 hours. This viral marketing campaign, also known as electronic word-of-mouth (EWOM), propelled the Old Spice brand into the forefront of consumers' minds, increased brand awareness, and inspired people to share the video links with others.

\section{Overview of E-WOM}

E-WOM is defined as “forwarding actions through email, instant messaging or other communication media that are of high 'addressability’” (Ho and Dempsey 2010, p. 1000). EWOM communication is traditional word-of-mouth (WOM) behavior evolved and adapted to electronic media, where individuals often convey messages in a one-to-many ratio. E-WOM differs from WOM in a few ways, including the convenience, asynchronous nature of electronic communication, potential for anonymity between the message sender and receiver, and lack of geographic boundaries. Aside from these differences, E-WOM is similar to traditional WOM in 
that it is a powerful form of marketing, it has more influence on consumers when compared to typical marketing avenues (Arndt 1967; Bansal and Voyer 2000), and consumers perceive it to be more credible and trustworthy (Brown and Reingen 1987; Day 1971; Murray 1991; Nyilasy 2004).

Coined by Rayport (1996), the phrase viral marketing originally described the act of attaching an advertisement in an email. Considered the original pioneer of viral marketing, Hotmail grew from 500,000 users to over 12,000,000 users in less than a year by simply attaching a small advertisement in the footer section of each email sent using the Hotmail service (Altoft 2008). Now, viral marketing is best defined as "electronic word-of-mouth whereby some form of marketing message related to a company, brand, or product is transmitted in an exponentially growing way” (Kaplan and Haenlein 2011).

Many marketing academics and practitioners use the terms E-WOM and viral marketing interchangeably. Due to the potential nature of E-WOM message to spread like a virus, it is also referred to as viral marketing. Viral marketing is also known as "word of mouse” (Goldenberg, Libai, and Muller 2001), viral communication (Welker 2002), buzz marketing (Notarantonio and Quigley 2009; Thomas 2004), viral stealth marketing (Swanepoel, Lye, and Rugimbana 2009), stealth marketing (Kaikati and Kaikati 2004), and word-of-mouth marketing (Kozinets et al. 2010).

E-WOM marketing has two crucial parts. The first is the growth rate, whereby each receiver of the electronic communication shares it with more than one other person. This reproduction rate is greater than one, which results in a potentially exponential growth rate. The second important component of viral marketing is the electronic media for sharing the message. This is commonly known as social media and includes blogs, microblogs, social networking 
sites, content communities, and collaborative projects (Kaplan and Haenlein 2011). In essence, consumers act as advertising agents for the organization by spreading the message through EWOM.

Technological advances have revolutionized the speed, convenience, and near-constant connectivity of individuals to their social networks. Being virtually connected nearly 24/7 substantially increases the opportunities for users to participate in E-WOM behavior, both on the forwarding and receiving ends. The ubiquity of mobile devices, including smart phones, tablets, and netbooks, has led researchers to use the phrase mobile marketing, which is defined as any type of marketing communication that uses mobile communication to promote marketing offerings (Pousttchi and Wiedemann 2006). The convenience of electronic communications paves the way for individuals to both easily receive and spread messages, which in turn leads to the viral effect. These E-WOM communications may be positive, as in the case of the Old Spice Man messages, or negative, which can be detrimental to the organization and the brand. In addition to investigating E-WOM about a company, this dissertation also explores e-servicescape and how consumers’ perceptions of the e-tailer.

Overview of E-Servicescape, Trust, Purchase Intentions, and Loyalty E-servicescape is defined as the online environmental factors of a marketer’s website (Harris and Goode 2010). E-servicescape may also be known as online servicescape and online environment. There are three dimensions of e-servicescape, namely aesthetic appeal, layout and functionality, and financial security. The first two dimensions were directly translated from Bitner’s (1992) research on brick-and-mortar stores’ servicescape. The final dimension, financial security, is critical in gaining consumers' trust, which in turn potentially increases purchase 
intentions. Aesthetic appeal is comprised of three sub-dimensions, including entertainment value, originality of design, and visual appeal. Four sub-dimensions are part of layout and functionality, namely customization, interactivity, relevance of information, and usability. Financial security is composed of two sub-dimensions, including ease of payment and perceived security.

The original e-servicescape definition and scale did not include customer reviews. However, individuals are increasingly relying on customer reviews to make purchase decisions, with 77\% of consumers reading reviews for electronic devices (Consumer Electronics 2013). Even more telling, $78 \%$ of Americans agree that online customer reviews influence their purchases (Purchase Decisions 2013). As a result of this growing trend, the present research includes customer reviews as a part of e-servicescape in the layout and functionality dimension. Aside from e-servicescape, this research also examines consumers' trust, and how trust is linked with E-WOM behavior, purchase intentions, and customer loyalty.

Trust plays a significant role in determining consumers’ actions regarding companies (Gefen and Straub 2004; Pavlou 2003). Trust in companies websites and online retailers is a key factor in the customer's sense of satisfaction from online transactions (Chen and Barnes 2007; Gefen and Straub 2004; Pavlou 2003). If customers trust e-tailers, they believe that e-vendors will treat them fairly and not behave opportunistically (Gefen, Karahanna, and Straub 2003; Shih 2004). Hence, online trust is an important determinant of success in the e-marketplace. Trust is the belief that an individual can rely on a promise made by another (Pavlou 2003).

In the context of e-commerce, trust includes the online consumers' beliefs and expectations about trust-related characteristics of the online seller (McKnight, Choudhury, and Kacmar 2002). The level of trust is positively related to the attitude towards the store, and inversely related to the perception of the risks involved in buying from that store (Jarvenpaa, 
Tractinsky, and Saarinen 1999). It is also suggested that a high level of trust by buyers stimulates favorable attitudes and behavior (Shergill and Chen 2005; van der Heijden, Verhagen, and Creemers 2003). A lack of trust in online companies is a primary reason why many consumers do not purchase online. Trust has been conceptualized as a set of distinct beliefs consisting of the integrity, benevolence, and ability of a given company (Gefen, Karahanna, and Straub 2003).

\section{Overview of Email and Social Networking Sites}

While some may say that email as a form of electronic communication is passé, email currently reaches three times more people than Facebook and Twitter combined, approximately 3.6 billion individuals (Lee 2014). Before abandoning email and jumping on the next bandwagon, marketers should carefully consider how consumers use email, both for the information that applies to them personally and as a way to share E-WOM. Previously, researchers have investigated individuals' forwarding behaviors in the context of emails as the electronic medium. The message source, content, and potential receivers' characteristics are factors in determining the propensity to pass along the email communication to others (Chiu et al. 2007). An individual's level of involvement, relational commitment, strength of social interaction tie, message forwarding self-efficacy, and affection outcome expectation are related to email-forwarding intentions (Huang, Lin, and Lin 2009). With constant evolutions in technology and electronic media, consumers also use other ways to share information, including social networking sites.

The omnipresent mobile devices and 24/7 connectivity make it easier for people to reach others and quickly post information on social networking sites, such as Facebook. Social networking sites differ from traditional media in that the content is both user-generated and user- 
centered, which allows people to establish and maintain online interactions (Boyd and Ellison 2007). While individuals enjoy being connected online and reading about others' experiences, opinions, and conversations, we like sharing our own thoughts, opinions, and likes/dislikes even more. Researchers found that the human brain gets more neurochemically activated when an individual is asked to disclose their own thoughts and feelings than when sharing another person’s thoughts (Tamir and Mitchell 2012). As we pass along E-WOM on Facebook, we inherently embed our own meanings in the message, even when the content originated from a marketer. Receivers of referral E-WOM through social networking sites are more likely to use the invitation to become a new member of the social networking site (Trusov, Bucklin, and Pauwels 2009). In this case, the E-WOM serves to generate hype about the social networking site and acquire new customers.

Theoretical Framework and Research Questions

Though the literature includes investigations on e-servicescape, viral marketing, emails, social networking sites, there is a gap in the marketing literature, namely how consumers’ perceptions of an e-tailer’s website are related to trust, E-WOM, purchase intentions, and customer loyalty. Although studies have explored online servicescape (Harris and Goode 2010), microblogs and e-servicescape (Tran, Strutton, and Taylor 2012), and online servicescape and flow (Lee and Jeong 2012), the extant research does not address how e-servicescape is associated with trust, E-WOM, purchase intentions, and loyalty. In particular, potential E-WOM in the context of emails and social networking postings originating from a marketer is examined. Towards these ends, this dissertation aims to address the following research questions:

1. Do a retailer's emails and social network postings influence customers' perceptions of the retailer's website differently? 
2. Do customer reviews play a role in customers' perceptions of the retailer's website?

3. How are customers' perceptions of the retailer's website related to trust? In turn, how is trust related to E-WOM intentions, purchase intentions, and customer loyalty?

One paradigm for this dissertation is stimulus-organism-response theory (Mehrabian and Russell 1974). This model describes how the environment is the stimulus that affects the organism. Then the organism responds with approach or avoidance behavior (see Figure 1). For the purposes of this research, the e-tailer's online servicescape is the stimulus, the organism's internal reaction is trust, and the behavioral responses include E-WOM, customer loyalty, and purchase intentions.

The network co-production model of E-WOM activity (Kozinets et al. 2010) serves as additional theoretical support for this research. Marketing has progressed from a transactionbased perspective to a more relationship-based view, where consumers play a major role in their networks (Vargo and Lusch 2004). The original communication is from the marketer, in the form of seeding. The seeded consumers then forward the communication to multiple others, often embedding their own message and meanings in the process. As co-producers in the network, users play an active part in the multi-directional flow of information among consumers (see Figure 2).

\section{Academic and Managerial Contributions}

The present research builds on current literature on E-WOM and e-servicescape. The findings contribute to the research stream on viral marketing and add to the understanding of EWOM effects on consumer behavior. In addition, this dissertation incorporates online servicescape with E-WOM and loyalty. Integrating the e-servicescape concept with SOR theory and the network co-production model of E-WOM enhances both academics’ and practitioners' 
understanding of the relationship between online servicescape and E-WOM. On the managerial side, these findings have important implications for marketing communication tactics, guiding organizations in crafting messages to encourage buzz marketing.

Given the technological advances in recent years, the pervasiveness connectedness via mobile devices and increased tendencies to share E-WOM, this research study is particularly timely. Individuals can conveniently pass along messages using various electronic media, with a quick post, text, email, chat, tweet, and more at the touch of a button. Aside from these consumer trends, another reason for this research study is that companies are continually seeking less expensive ways to reach potential customers, which include E-WOM through the Internet (Whitman 2006). However, E-WOM behavior is not entirely understood, and there is much interest in discovering how commercial messages are diffused from one consumer to another through E-WOM.

\section{Overview of Research Design}

The present research uses survey methodology to investigate the relationships between eservicescape, trust, purchase intentions, customer loyalty, and E-WOM intentions. Customers of an almost-exclusively online and catalog retailer were invited to complete the online survey questionnaire. Structural equation modeling was used to analyze the responses. In addition, two different groups of customers were compared using multi-group analysis, where one group of users received emails from a marketer and the other group received social network postings from the same marketer. The same survey questionnaire was administered to both groups, with some scale items adapted for the particular E-WOM communication (i.e., email versus social network 
posting). Most of the variables were measured using previously validated scales from the marketing literature. A few scale items were developed specifically for this study.

The remainder of this dissertation is organized as follows. Chapter 2 reviews the relevant literature, theoretical background, research model, and hypotheses development. Chapter 3 explains the methodology used to test the research model. Chapter 4 includes the statistical results. Finally, the major findings, implications, limitations, and suggestions for further research are discussed in Chapter 5. 


\section{CHAPTER 2}

\section{LITERATURE REVIEW, THEORETICAL BACKGROUND, AND HYPOTHESES DEVELOPMENT}

Overview

In this chapter, the theoretical background and relevant literature are reviewed. First, the existing stream of literature on servicescape and online servicescape are discussed in detail. Second, the literature on traditional word-of-mouth (WOM) and E-WOM is reviewed. Next, the literature on trust, customer loyalty, and purchase intentions are considered. The final section of this chapter includes the research theoretical framework and development of the research model and hypotheses.

\section{Literature Review}

\section{Servicescape}

Servicescape describes the physical environment of the service factory and how it affects the customer experience, as well as employees’ experiences (Booms and Bitner 1982).

Servicescape elements include factors that impact the performance, delivery, and consumption of market offerings (Zeithaml, Bitner, and Gremler 2009). Perceptions of the servicescape impact individuals’ approach/avoidance behaviors (Hui and Bateson 1991). For example, consider two restaurants with identical food quality. The first is a small, mom-and-pop restaurant. The other is part of a national, well-known franchise chain. While the food tastes the same, the customer experience in the family-owned restaurant may earn higher ratings on the perception scale. These more positive perceptions are attributed to the service environment, which includes friendliness of employees, furnishings, and wall décor. The servicescape concept has been used to understand 
how consumers perceive the service environment, and how this perception impacts their opinions, beliefs, and physiological responses (Bitner 1992).

Servicescape for brick-and-mortar stores consists of three dimensions: ambient conditions; spatial layout and functionality; and signs, symbols, and artifacts (Bitner 1992). Researchers have investigated how ambient conditions influence human perceptions of the environment, as well as their responses to the environment (Baker, Berry, and Parasuraman 1988; Donovan et al. 1994; Sherman, Mathur, and Smith 1997; Spangenberg, Grohmann, and Sprott 2005; Wineman 1982). For physical stores, ambient conditions affect the five senses. Examples of environmental ambient conditions include scent, sound, lighting, and temperature. Spatial layout and functionality, the second dimension of servicescape, are chief components of the physical surroundings. Spatial layout is the arrangement of the furniture, machines, and equipment, as well as the space between them. The size and shape of fixtures and furnishings are also part of spatial layout. Functionality is how these items perform in the process of fulfilling specific consumer needs. Researchers have explored how spatial layout and functionality influence employees (Sundstrom and Sundstrom 1986; Wineman 1982) and customers (Baker, Grewal, and Parasuraman 1994; Groeppel-Klein and Bartmann 2008; Kim and Jin 2001; Park, Iyer, and Smith 1989).

The final dimension of servicescape is about signs, symbols, and artifacts. These items convey explicit or implicit signals, and sometimes both, about the service factory (Bitner 1992; Davis 1984). Explicit signals include signs communicating names, behavioral expectations and rules, and directions for customers. While inherently more complex than explicit signals, implicit signals are still important communicators of quality, experience, and expectations. For example, the quality of artwork, furniture, and décor are all part of consumers' general impressions and 
evaluations of the physical environment. Specific cues can be used to convey prestige, professionalism, and status, such as high-end furniture, awards, diplomas, certificates, color, and placement (Davis 1984; Peters 1978; Sundstrom and Sundstrom 1986). It can be difficult to dissect the meanings of implicit signals since the symbolic connotations can be highly related to each individual's personal, cultural, or socioeconomic background.

Consumers' perceptions of servicescape are holistic in nature, and the cues are interactively related in the formation of these perceptions. The perceptions affect beliefs and emotions, which in turn influence behavior. A person's response to the physical store environment mediates behaviors (Bitner 1992), such as purchase, repeat visits, and WOM communications. The cognitive and affective responses are interdependent, and one may impact the other. Overall, positive sensations of the store design influenced consumers' willingness to stay longer and increased purchase intentions (Fiore, Yah, and Yoh 2000; Mattila and Wirtz 2001; Yalch and Spangenberg 1990).

\section{Expanding the Servicescape Framework}

The original servicescape dimensions, namely 1) ambient conditions; 2) spatial layout and functionality; and 3) signs, symbols, and artifacts, only addressed the environmental components of the physical store setting. An expanded framework for servicescape was proposed, which included the physical, social, socially-symbolic, and natural dimensions. All of the original servicescape dimensions from Bitner (1992) are part of the physical dimension. This dimension encompasses cleanliness, sound, visual, scent, space, symbols, and signs (Rosenbaum and Massiah 2011). 
The social dimension is related to the employees, other customers, and social density (Edvardsson, Enquist, and Johnston 2010). Individuals shop to fulfill utilitarian needs, as well as social and psychological needs (Bagozzi 1975). We shop for the social aspect of the experience, and social interactions with other customers and store employees (Rosenbaum and Montoya 2007). Aside from the social dealings with other consumers, the number of customers in the store space influences decisions and behaviors. Known as social density, this crowding, or lack of crowding, in stores may be beneficial or detrimental to the business. For store environments where social interactions increase the enjoyment level of the consumption experience, high social density is desirable and leads to positive customer responses (Eroglu, Machleit, and Barr 2005; McGrath, Sherry, and Heisley 1993; Turley and Milliman 2000). On the other hand, too much crowding influences consumers' decision to avoid stores with high social density (Harrell, Hutt, and Anderson 1980).

The socially-symbolic dimension of servicescape refers to how businesses may intentionally use signs, symbols, and artifacts with symbolic significance to impact consumer behavior (Rosenbaum 2005). In particular, organizations may employ these signals to attract certain ethnic consumers. Firms are limited in the creation of symbolic meanings of signs and artifacts due to the nature of how meaning is created, embedded, and evolved by social groups (Durkheim 1912). However, businesses may employ the known symbols of an ethnic group (Berger and Luckmann 1966) to draw in consumers (Rosenbaum 2005). These displayed artifacts, embedded with significance, provide tangible cues about the other customers of the establishment. This serves as part of the "welcoming servicescape” for group members (Rosenbaum and Massiah 2011, p. 478). 
Finally, the last dimension of the expanded servicescape framework is the natural dimension, which is about the innate connection between humans and other living systems (Wilson 1984). The natural part of servicescape may affect consumers’ approach/avoidance behaviors, health, and well-being (Rosenbaum 2009). Attention restoration theory, which posits that humans can concentrate better after time spent in nature, supports this research (Kaplan and Kaplan 1989). While it may appear as if all natural environments may offer the benefits of restoration and relaxation, this is not the case. Specifically, there are three important stimuli in naturally restorative settings, which include being away, fascination, and compatibility (Han 2007). Being away is about escapism, and getting away from one’s daily environment. It may be a temporary reprieve from life's stresses, but the break is restorative. Fascination is about the environment holding the individual's attention, and he or she wants to be there because of this fascination (Kaplan 1995). The last stimulus of the natural dimension is compatibility, which refers to how a person feels as if they belong, and they can interact without feeling socially inept, inferior, or embarrassed (Kaplan 1995).

\section{E-Servicescape}

Online shopping continues to grow, and for the first time, the number of consumers shopping online for holiday gifts has surpassed brick-and-mortar stores (Deloitte 2013).

Consumers like browsing and purchasing online for the convenience, greater variety, potentially lower prices, and the ability to easily compare market offerings and prices. In addition, some shoppers prefer for goods to be delivered directly to their home. For the holiday season of 2013, 47\% of shoppers anticipated purchasing gifts online (Deloitte 2013) as compared to 35\% from 2010 (Deloitte 2010). Furthermore, smartphone ownership has increased to 61\% and 68\% of 
these technologically-connected consumers use their mobile devices for holiday shopping (Deloitte 2013). With the rising popularity of online shopping, e-tailers must consider the importance of consumers' perceptions of their websites, and work to continually improve their sites’ functionality and service. With this in mind, Harris and Goode (2010) translated the concept of servicescape for physical stores to e-commerce stores. The researchers named this $e$ servicescape (also known as online servicescape) and defined it as "the online environment factors that exist during service delivery” (Harris and Goode 2010, p. 231). Scale items were developed and validated to measure e-servicescape (Harris and Goode 2010).

Online servicescape consists of three dimensions, aesthetic appeal, layout and functionality, and financial security. The first dimension, aesthetic appeal, is derived directly from the ambient conditions dimension of servicescape for brick-and-mortar stores (Harris and Goode 2010). For e-commerce businesses, sight and sound are the senses used to attract individuals. Aesthetic appeal is composed of three sub-dimensions: entertainment value, originality of design, and visual appeal. Compared to the physical store environment, online consumers are not able to use tactile senses to observe products. Therefore, quality photographs must be provided to influence users (Kim and Lennon 2008; Lin 2007). Visual appeal speaks directly to the sight sense, and interesting graphics, fonts, and photographs entice consumers to spend more time viewing the website. Entertainment value and originality of design may appeal to both sound and sight. For all three sub-dimensions of aesthetic appeal, if the content is fresh, new, and pleasing, consumers will be drawn to the website and more likely to visit often. Current technology for websites does not address the touch, smell, and taste senses.

The second dimension of online servicescape, layout and functionality, is related to spatial layout and functionality from servicescape for physical stores (Harris and Goode 2010). 
Similar to how furnishings and the spatial layout of stores influence consumers' perceptions, a website's layout also impacts individuals' evaluations of the both website and business. Layout includes the structure, organization, and arrangement of websites. Customers prefer online stores which are arranged in a convenient manner that is easy to understand and navigate. Moreover, the website, and all associated links, must perform as expected, which is the functionality aspect of this dimension. The website design must be functional, and this is an influential attribute of user evaluations and behaviors (Donnelly 2000; Mandel and Johnson 2002; Menon and Kahn 2002).

As originally conceived by Harris and Goode (2010), layout and functionality has four sub-dimensions: customization/personalization, interactivity, relevance of information and usability. Customization is the modification of the website to meet each individual's needs and wants. Some websites feature tools to allow consumers to personalize the website according to their preferences (Grewal, Mullikin, and Munger 2003). While some researchers argue that the possibility of erroneously personalizing for consumers is more harmful than the benefit of customization (Frels and Kannan 2001), others believe that e-tailers' customization of websites indicates customer focus, which leads to increased visits and more purchases (Parsons, Zeisser, and Waitman 1998). Creating a website that emphasizes customization is a direct extension of the marketing concept, and helps firms to better serve consumers' needs and wants and puts customers at the center of the business. Users' website evaluations are strongly linked to customization and personalization (Huizingh 2002; Menon and Kahn 2002). With advances in technology, customizing websites is easier and more economically feasible for companies (Shapiro and Varian 1999). 
Interactivity is the two-way transfer of information between the user and the central point of communication, which is usually a continuous process. When consumers perceive higher levels of interactivity for a website, their online shopping experience is enhanced (Chen and Chang 2003; Fiore and Jin 2003; Srinivasan, Anderson, and Ponnavolu 2002). Perceptions of website interactivity is a main element of consumers' responses and behavioral outcomes for online shopping (Fiore and Jin 2003; Li, Daugherty, and Biocca 2001). The level of interactivity impacts attitudes toward the e-tailer, the likelihood of revisiting the website, and purchase intentions (Gehrke and Turban 1999; Hartnett 2000; Li, Daugherty, and Biocca 2001; Shih 1998).

Relevance of information refers to how pertinent and connected the content is to users. This particular website attribute is another essential component of consumers' website evaluations (Bauer, Grether, and Leach 2002; Zeithaml, Parasuraman, and Malhotra 2002). Material included on any webpage within the site must be closely related and applicable, and also serves to attract potential customers through search engines (Griffin 2007). Relevance is the basis for deciding on content, and consumers rate websites based on their information needs (Montoya-Weiss, Voss, and Grewal 2003).

Usability refers to ease of navigation and maneuverability of the website, and is cited as the most influential way in which users assess websites (Donnelly 2000). The e-tailer's navigational tools are positively associated with shoppers' exploratory behaviors while on the website (Richard 2005). Consumers’ website evaluations emphasize navigation and usability (Evans and King 1999; Hoque and Lohse 1999). Users lose interest and patience when website load time is too long, links on pages no longer exist, and flash technology requires long wait times (Meyers 2014). The main navigation needs to be clear, readily available, and easy to read 
(Meyers 2014). Moreover, the website should feature a keyword search function allowing consumers to quickly find information. This search button should be prominently displayed (Meyers 2014). The average key business metrics improved 83\% after website redesign to enhance usability (Nielsen 2008). Considering this high return on investment, organizations should focus on website usability to attract and retain customers.

Online shopping offers many advantages, such as convenience, 24/7 availability, and the ability to shop in the comfort and privacy of your home. However, financial security is a potential deal breaker when it comes down to completing the online transaction. Online financial security includes users' perceptions of the website's security and safety measures and the actual payment processes. Financial security has two sub-dimensions: perceived security and ease of payment. Researchers have found that security is necessary in the online exchange process (Montoya-Weiss, Voss, and Grewal 2003; Schiffman, Sherman, and Long 2003; Szymanski and Hise 2000). Website security is a strong factor for satisfactory experiences with online businesses (Montoya-Weiss, Voss, and Grewal 2003; Szymanski and Hise 2000). Aside from online security, consumers desire ease during the payment procedure. Ease of payment includes efficiency during the payment process, perceived ease of use for payment facilities, and not requiring many details during this part of the transaction. This is another important aspect of website evaluations (Chen and Chang 2003). Financial security is closely linked to another construct of interest for this dissertation, namely trust.

All the dimensions and sub-dimensions of online servicescape impact atmospheric responsiveness. Atmospheric responsiveness is consumers' tendency to make patronage decisions based on the store’s qualities (McKechnie 1974). For e-commerce businesses, researchers have found that specific online cues influence the relationship between the e-tailer's 
online atmosphere and consumer purchase decision and other behaviors (Eroglu, Machleit, and Davis 2001; Fiore and Kim 2007). Aside from purchases, an e-tailer’s atmosphere influences shoppers' amount of time spent browsing and likelihood to revisit the website in the future.

The online store environment impacts consumers’ attitudes, satisfaction level, and approach/avoidance behavior regarding the e-tailer; affective responses mediate this relationship (Eroglu, Machelit, and Davis 2003). The more agreeable the website environment, the more consumers were aroused, which led to approach responses toward the e-tailer. Researchers found that website quality and positive affect explained purchase intentions and customer loyalty (Lynch, Kent, and Srinivasan 2001).

Harris and Goode’s (2010) conceptualization and scale development for e-servicescape encompassed many crucial factors in the online service delivery environment. However, with the consistent evolution of technology and consumers' expectations, more is expected of online servicescape. In particular, in this information age where consumers want access to more details, and information from non-marketing sources, customer reviews are essential for e-tailers. While customer reviews have been investigated in different contexts (Berger, Sorensen, and Rasmussen 2010; Chatterjee 2001; Chen and Xie 2004; Park, Lee, and Han 2007), researchers have not studied product reviews as part of e-servicescape. The present research intends to fill this gap and include customer reviews as part of online servicescape.

\section{Customer Reviews}

Consumers shopping online face the challenge of not being able to smell, touch, or try on the products, which are major disadvantages when compared to purchasing from brick-andmortar stores. An e-tailer can provide potential customers with two categories of product-related 
information. The first category of information is marketer-driven, including traditional communication methods such as advertisements. In addition, seller-created content about products is offered on the website. The second category of information is consumer-created (Chatterjee 2001; Chen and Xie 2004; Park, Lee, and Han 2007). These customer reviews, which include experiences, evaluations, and opinions, originate from users who have purchased and consumed the product (Park, Lee, and Han 2007). When consumers read product reviews from other consumers, the information provided is helpful in the decision-making process. Customer reviews are an important factor in online sales (Chen and Xie 2005). Many online shoppers consider reviews as an essential part of their decision-making process.

Considered an independent and unbiased source of information, the importance and popularity of customer reviews has grown (Chen and Xie 2004; Hennig-Thurau and Walsh 2004). Moreover, it is considered a form of E-WOM communication. Like traditional WOM, customer reviews (as E-WOM) are perceived to be more credible than marketer-driven messages through traditional channels. Seventy-nine percent of consumers trust online reviews as much as personal recommendations (Anderson 2013). Research has shown that the quality of customer reviews has a positive effect on shoppers' purchase intentions (Park, Lee, and Han 2007). Information usefulness and source credibility influence the adoption of online opinions (Cheung, Lee, and Rabjohn 2008). Beyond web shopping, customer reviews even influence shoppers in physical stores. Many shoppers use their smartphones to access customer reviews during their instore shopping experience before making their final purchase decision (Charlton 2010). Customer reviews differ from traditional WOM in three ways. First, customer reviews have the potential to reach many others. Without geographical boundaries, customer reviews may reach individuals in all parts of the world (Chatterjee 2001). In contrast, the reach of traditional WOM 
is limited to a person's social circle. Online retailers have the power to decide which customer reviews will be displayed on their website. In addition, firms also control the format, design, and number of reviews shown to consumers. Businesses may choose to publicize only advantageous review information to potential customers. Lastly, customer reviews vary from traditional WOM in the issue of credibility. While the information is still WOM, which is more trustworthy than the e-tailer information, customer reviews originate from individuals that are strangers. Compared to traditional WOM from a family member, friend, or neighbor, customer reviews are from total strangers. Duan, Gu, and Whinston (2008) found that people trust online reviews from strangers. For college students, the weak social tie strength of online reviews is more influential in the selection of professors (Steffes and Burgee 2009). Some users may doubt the authenticity of online product reviews.

Despite the potential concerns regarding how genuine the reviews are, consumers are more likely to trust customer reviews than seller-created product information (Dellarocas 2003). Worldwide, 70\% of consumers trust online consumer reviews (Nielsen Global 2012). E-tailers’ product information may not provide details about the negative aspects of the merchandise, and mainly focus on the positive characteristics. Furthermore, professional photographs of goods sold online may not accurately portray products. On the other hand, customers offer frank reviews of goods, often including the strengths and weaknesses. Another advantage of customer reviews is how consumers provide additional usage situations for the market offering. This leads users to trust customer reviews more than seller-created information.

Customer reviews vary from a simple, numeric rating system to more complex questions about specific features, design, value, ease of use, etc. Many e-tailers incorporate both, with a numeric rating for overall impression and various other questions regarding the market offering. 
Often, e-tailers provide an average overall rating of all customer reviews, which is practical for consumers who want quick information. In addition, some websites offer the opportunity for customers to write general comments in a text-box format.

E-commerce sites with many reviews even allow users to rate the review itself as "helpful” or "not helpful”. Amazon uses this feature, and even ranks the reviews as "most helpful.” Amazon created algorithms to prioritize the most helpful customer reviews and bump this information to the top of the page. Interestingly, consumers find comfort in seeing that a large number of reviews is available (Park and Lee 2008). In addition, researchers found that purchasing intentions grow with an increase in the number of reviews (Park, Lee, and Han 2007). On the other hand, Davis and Khazanchi (2008) found that the sheer volume of customer reviews does not impact sales. Time constraints usually prevent potential customers from reading every single review, especially when products have several hundred reviews on popular e-tailers' sites. This system of indicating the level of helpfulness is particularly useful and well-received for users who do not want to sift through hundreds of customer reviews.

With consumer-generated information, businesses face both positive and negative comments from users. For books written by established writers, online sales increased from $32 \%$ to 52\% with good online reviews (Berger, Sorensen, and Rasmussen 2012). As expected, bad reviews for books by these same authors resulted in $15 \%$ decreased sales. However, companies should not always fear negative customer reviews. The same researchers found that undesirable reviews for unknown authors increased sales by an average of $45 \%$. This is likely due to more heightened awareness, which indicates bad reviews can actually aid in product sales (Berger, Sorensen, and Rasmussen 2012). Depending on the particular details of the situation, negative customer reviews may actually prove to be advantageous to e-tailers. Moreover, adverse 
comments may serve as practical information for companies to improve their market offerings and level of service.

Trust

For online shopping, trust in the e-tailer is a crucial element in customers' satisfaction from their purchases on e-commerce businesses (Chen and Barnes 2007; Gefen and Straub 2004; Pavlou 2003). For some, general trust in the Internet as a medium for shopping is an issue (McCole, Ramsey, and Williams 2010) and previous research has shown that individuals are more likely to purchase online if they have more trust in the Internet and more experience using the Internet (Corbitt, Thanasankit, and Yi 2003). Moreover, perceived quality of a website is related to trust, which is associated with purchase intentions (Everard and Galletta 2006).

Purchase decisions online involve uncertainty and dependency, which makes trust even more essential for e-tailers when compared to brick-and-mortar stores. Uncertainty stems from not knowing how the transaction will be executed, if the company will treat the customer fairly, and if the customer's identity and personal information will be kept private and confidential. Online shoppers put faith in e-commerce firms and depend on the companies to be fair and prioritize this information. E-tailers must work to overcome the risks consumers face in purchasing online, including anonymity, distance, and lack of physical interactions (Cazier, Shao, and St. Louis 2006). In physical stores, sales people may use facial expressions, gestures, and body language to convey trust. This is a clear disadvantage for e-tailers in gaining consumers’ trust (Grabner-Kräuter and Kaluscha 2003).

Trust is difficult to define, mainly because it is a context-dependent concept. For the purposes of this research, trust is defined as the belief that one can rely on a promise made by 
another (Pavlou 2003). For online businesses, earning consumers’ trust means understanding their expectations for trust and their beliefs regarding the e-tailers' trust-related characteristics (McKnight and Chervany 2002). E-commerce firms must convince consumers to believe that they will treat consumers fairly (Gefen, Karahanna, and Straub 2003; Shih 2004). Attitude towards the store and trust have been positively linked (Jarvenpaa, Tractinsky, and Saarinen 1999; van der Heijden, Verhagen, and Creemers 2003). Consumers’ perceptions of risk is an obstacle for online shopping (Forsythe and Shi 2003).

Researchers have also found that increased trust means less perceived risk in purchasing from the e-tailer (Jarvenpaa, Tractinsky, and Vitale 2000; McKnight, Choudhury, and Kacmar 2002). Lack of trust in e-commerce businesses is often cited as the main reason why consumers hesitate to buy online. Greater trust from shoppers promotes more positive attitudes toward the etailer and leads to purchase behavior (Shergill and Chen 2005).

Gefen, Karahanna, and Straub (2003) conceptualized trust as a set of distinct beliefs regarding the ability, benevolence, and integrity of a firm. Ability is related to the competencies and characteristics of the business. This ability refers to the firm's influence and authority in a specific domain (Mayer, Davis, and Schoorman 1995). Benevolence is the consumer's belief that the seller is interested in the consumer's welfare, and does not intend to behave opportunistically. Benevolence also involves the consumer's belief that the firm is willing to work towards mutually satisfying exchange relationships rather them simply seeking to maximize profits (Mayer, Davis, and Schoorman 1995). Finally, integrity describes the principles of the company. Integrity includes the belief that the firm will keep consumers' information confidential. Moreover, integrity is about honesty, following expected rules of conduct, and keeping promises. The e-tailer's integrity has been found to be a major positive factor of consumer trust in online 
shopping (Lee and Turban 2001). Fundamental questions consumers have about an e-tailer’s integrity include sincerity of the organization and fulfillment of promises (Mayer, Davis, and Schoorman 1995). At first glance, it may appear that benevolence and integrity overlap. However, benevolence is more about general concern for customers versus integrity, which refers to the company’s standards for maintaining consumer confidentiality and keeping promises.

Trust is often linked with customer loyalty. If a customer has a high level of trust in an organization and believes the firm will be fair and just, the likelihood of loyalty grows (Flavián and Guinalíu 2006). Trust in an e-tailer directly impacts loyalty (Kim, Jin, and Swinney 2009; Ribbink et al. 2004). In the world of e-commerce, loyalty is defined as a customer's favorable attitude and commitment toward the e-tailer and includes repeat purchases (Srinivasan, Anderson, and Ponnavolu 2002). Dedicated customers will forgo seeking price deals and willingly pay premium prices. Moreover, loyal patrons are committed, and reduce the potential costs associated with acquiring new customers (Markey and Hopton 2000).

In the context of online shopping, trust has been investigated by many researchers. When Internet stores were relatively new, the concern was gaining consumers' trust in the Internet as a medium (Cheung and Lee 2000; Corbitt, Thanasankit, and Yi 2003; Hoffman, Novak, and Peralta 1999; Siau and Shen 2003). Over time, research on trust has evolved and the relationship between specific e-tailers and trust has been studied (Harris and Goode 2010; Lee and Turban 2001; McKnight, Choudhury, and Kacmar 2002; Tran, Strutton, and Taylor 2012; van der Heijden, Verhagen, and Creemers 2003). The research involving trust and e-commerce businesses used consumer-selected websites to measure perceptions of the various e-tailers' sites and trust. Research has not been conducted on customers and their perceptions of the same e- 
tailer. This study seeks to fill this gap in the literature and investigates customers' perceptions of the same e-tailer in regards to e-servicescape and trust.

\section{Traditional Word of Mouth}

Word of mouth (WOM) is the influence of people's conversations on consumer behavior, including attitudes, perceptions, and purchase decisions. Current studies on WOM communications stem from research on the role of interpersonal influence on consumer decision making (Katz and Lazarsfeld 1955). WOM activity is defined as "informal communications directed at other consumers about the ownership, usage, or characteristics of particular goods and services and/or their sellers” (Westbrook 1987, p. 261). Similarly, Arndt (1967, p. 291) defined WOM communications as "oral, person-to-person communication between a perceived noncommercial communication and a receiver concerning a brand, a product, or a service offered for sale”.

WOM is a powerful marketing tool, and some believe it is the most effective method of reaching consumers (Keller 2007). Many consumers view WOM as a more trustworthy, authentic, and easily accessible source of information, especially when compared to companysponsored advertising (Borgida and Nisbett 1977; Brown and Reingen 1987; Day 1971; Murray

1991; Silverman 1997). Approximately 67\% of consumer product sales in the U.S. directly stem from WOM information among family, friends, and co-workers (Rosen 2009). WOM also influences customer loyalty more than marketing-controlled campaigns (Bansal and Voyer 2000; Buttle 1998; Chung and Darke 2006; Day 1971; Park and Lee 2009; Sheth 1971).

Furthermore, when compared to traditional marketing efforts, WOM communications have more impact (Bickart and Schindler 2001; Brooks 1957; Engel, Kegerreis, and Blackwell 
1969; Katz and Lazarsfeld 1955; Notarantonio and Quigley 2009) and generate more responses (Trusov, Bucklin, and Pauwels 2009). Organizations may also promote WOM activity to bolster their marketing efforts, which is cost-effective and can result in new customers (Kumar, Petersen, and Leone 2007). Aside from gaining additional customers, firms benefit when the customer lifetime value increases for individuals who engage in WOM activity (Lee, Lee, and Feick 2006).

WOM communications shape people's attitudes and subsequent consumption behaviors. WOM activity is powerful and effective in the information search stage of the consumer decision making process, selection of business for patronage, and the post-consumption stage (Gilly et al. 1998; Murray 1991). Consumers are more likely to depend on WOM information to make purchase decisions about services (Murray 1991; Zeithaml and Berry 1993). Product and movie ticket sales revenue have grown due to WOM communications (Bayus 1985; Chevalier and Mayzlin 2006; Liu 2006). In addition, WOM communications promote diffusion of new products and technological innovations (Arndt 1967; Brown and Reingen 1987; Childers 1986; Czepiel 1974; Herr, Kardes, and Kim 1991; Mahajan, Muller, and Bass 1990).

People are part of interpersonal networks, where individuals seek information and dispense information to influence other consumers (Brooks 1957). Personal sources have been found to play an influential role in impacting product choice (Katz and Lazarsfeld 1955; Price and Feick 1984). Compared to non-opinion leaders, individuals who are opinion leaders are more influential and engage in more WOM activity (Engel, Blackwell, and Miniard 1990; Rogers 1995). Due to this, marketing practitioners have focused on opinion leaders for generating WOM information. Despite this orientation towards opinion leaders, researchers have found that non- 
opinion leaders also share WOM communications. Satisfied customers tend to generate positive WOM (Bitner 1990). Dissatisfied individuals generate negative WOM (Richins 1983).

Previous research has shown that there are four different categories of motivations for individuals to engage in WOM (Dichter 1966). The first is involvement in the product, which is when the consumer feels passionately about the market offering and wants to share information with others. Another motivation for dispensing WOM is self-involvement. An individual may be motivated to tell other consumers about a product or service when he or she desires attention and wants to show that that he or she is updated and aware of the latest information. Otherinvolvement is another motivation for initiating WOM conversations, where a person wants to help others by sharing WOM about an experience. Finally, message-involvement is when consumers talk about the advertising message from the company, even when they have not bought and used the product or service (Dichter 1966). Other- and product-involvement focus on the actual product or service. Self-involvement is a combination of both the product and the desire for self-promotion. Message-involvement emphasizes the marketer's message, which is related to the product or service on some level. While the four motivations vary, the common theme is the market offering, but to different extents.

As for the consumers who pay attention to and listen to others' WOM communications, they are evaluating both the messenger and information. The listener is trying to determine the sharer's empathy, which involves deciding if the recommender is sincerely interested in him or her and his or her well-being. Furthermore, the individual is trying to assess the speaker's honesty. Aside from empathy, the listener is also evaluating the recommender's credibility. The WOM sharer's experience and knowledge about the product or service should be convincing before the listener is willing to put stock in the WOM advice. 
Researchers have shown that individual differences affect one's likelihood to engage in WOM activity. Innovators, the first consumers to adopt new products, disseminate more WOM messages than non-innovators (Engel, Kegerreis, and Blackwell 1969). Personality has also been studied in the context of WOM communications. The personality trait of openness to experience has been linked to receivers of WOM messages (Mowen, Park, and Zablah 2007). In addition, the personality characteristic of need for materialistic resources was associated with both disseminating and listening to WOM information. As expected, the trait of susceptibility to influence was positively associated with receiving WOM messages (Mowen, Park, and Zablah 2007).

Feick and Price (1987) described market mavens as individuals with a tendency to provide general shopping and marketplace information to other consumers. Market mavens gather and disseminate WOM information about different brands, products, and stores, and frequently share this knowledge. In the WOM process, market mavens may initiate the conversation, or simply respond to others' requests regarding products, stores, or services. Their influence on others and wide range of general knowledge about products and services make market mavens particularly appealing to marketers.

\section{Electronic Word of Mouth}

Several definitions of electronic word of mouth (E-WOM) have been considered for the present research. Petrescu and Korgaonkar (2011, p. 219) defined it as "electronic consumer-toconsumer communication regarding a brand or product.” This particular definition is too broad for this research. E-WOM has also been defined as "any positive or negative statement made by potential, actual, or former customers about a product or company, which is made available to a 
multitude of people and institutions via the Internet” (Hennig-Thurau et al. 2004, p. 39). Compared to the first definition of E-WOM, this definition explicitly states the types of consumers involved in E-WOM. However, for the research at hand, this E-WOM definition is too vague and insufficient. Another definition (Ho and Dempsey 2010, p. 1000) describes EWOM activities as "forwarding actions through email, instant messaging or other communication media that are of high 'addressability'.” Compared to the other definitions of EWOM, this definition is appropriately specific and refers to the exact methods of electronic communication available for customers of a specific e-tailer to engage in E-WOM activity, namely email and social networking sites. This is the definition of E-WOM adopted for the present research.

E-WOM parallels traditional WOM in some ways. Consumers use information from EWOM communications to make purchase decisions, similar to traditional WOM conversations (De Bruyn and Lilien 2008; Godes and Mayzlin 2004). For some E-WOM, there is an interpersonal aspect to the communication. For example, in social networking sites, instant messages, text messages, and e-mails, there is a relationship between the sender and receiver of the information. In addition, the concept of the interpersonal network of consumers (Brooks 1957) is also extended from WOM to E-WOM communications for some cases of E-WOM activity.

Despite these similarities, differences exist between traditional WOM and E-WOM. To start with, E-WOM communications can be easily and quickly passed along from one individual to another person or from one person to many people. With consumers' constant connectivity, EWOM is even more influential. Fifty-six percent of American adults own smart phones (Smith 2013). With smart phone usage on the rise, individuals can conveniently disseminate and access 
E-WOM messages. Any consumer with an interest and Wi-Fi connectivity has the opportunity to easily express their opinions and thoughts to many others.

Any communication may be rapidly spread to many individuals, like a virus; hence, electronic marketing is also commonly known as viral marketing. E-WOM is also called word of mouse (Goldenberg, Libai, and Muller 2001), viral communication (Welker 2002), buzz marketing (Notarantonio and Quigley 2009; Thomas 2004), viral stealth marketing (Swanepoel, Lye, and Rugimbana 2009), stealth marketing (Kaikati and Kaikati 2004), and word-of-mouth marketing (Kozinets et al. 2010). Since E-WOM occurs via electronic communications rather than in the face-to-face context, there are no geographical boundaries. Part of the viral nature of E-WOM communications is due to this lack of geographical limitations.

Another distinctive characteristic of online communications is the asynchronicity (Henderson and Gilding 2004; Hung and Li 2007), which makes it easier for consumers to obtain information at their convenience (Sun et al. 2006). Another advantage of E-WOM communications is that most of it is archived and available in the future (Hennig-Thurau et al. 2004; Herr, Kardes, and Kim 1991; Hung and Li 2007). Consumers can quickly access and easily read information from others, regardless of geography or time issues.

Often times, E-WOM information is more candid because people are more willing to be honest and forthcoming online (Roed 2003), which in turn makes it more influential than traditional WOM in the absence of face-to-face human pressure (Huang, Hsiao and Chen 2012; Phelps et al. 2004). Trust is positively related to intention to exchange EWOM communications in online communities (Chu and Kim 2011; Jarvenpaa, Knoll, and Leidner 1998; Ridings, Gefen, Arinze, and 2002). Furthermore, users are more likely to believe E-WOM messages when both the positive and negative are presented. Furthermore, consumers can easily find opinions of 
strangers online. This rarely happens in traditional WOM, which makes E-WOM communications substantially more powerful.

Firms can use the viral nature of E-WOM to their advantage. Rather than spend money on television commercials, organizations should focus on promotional strategies via electronic media, such as E-WOM and blogs (Whitman 2006). Emphasizing viral marketing campaigns is less expensive and potentially more effective when it reaches more people (Ferguson 2008). Similar to how WOM communications exert more influence on consumers than traditional, company-sponsored advertising (Arndt 1967; Dichter 1966; Haywood 1989; Whyte 1954), EWOM communications have a stronger impact on consumer behavior, including purchase decisions (De Bruyn and Lilien 2008). Moreover, consumers seek and prefer other users’ evaluations and recommendations rather than company-generated information (De Bruyn and Lilien 2008). Consumers perceive brand-related information from other consumers on social media sites to be more valuable than marketer-generated messages (Mangold and Faulds 2009). Therefore, organizations endeavor to recruit individuals to become promoters of their brand, product, or service and disseminate the marketing communications. The consumer is an active co-producer in the marketing process (Vargo and Lusch 2004), and this can be used by companies to their advantage.

\section{Interactive Electronic Word of Mouth Campaigns}

Marketers use the interactive opportunities of electronic communications to aid their viral marketing campaign efforts (Lombard and Snyder-Duch 2001). Employing interactivity as part of viral marketing gives companies the chance to better understand consumers, which can lead to more strategic marketing to gain customers in the target market segments (Pavlou and Stewart 
2000). Consumers also benefit from interactive campaigns because they can express their thoughts and opinions. There is also the potential for consumers to be active co-producers when new product ideas are presented for sweepstakes and contests (Vargo and Lusch 2004); involving consumers in the product development process generates excitement and publicity for the company (Okazaki 2009).

Motivations to Engage in Electronic Word of Mouth

Consumers' motivations to engage in E-WOM are similar to the four motivations of WOM (Dichter 1966). Ho and Dempsey (2010) investigated the motivational factors of Internet users' incentives to forward online content. They based their study on the theory of fundamental interpersonal relations orientation (FIRO) (Schutz 1966), which posits that individuals have three interpersonal needs. People seek affection, control, and inclusion when part of a group community. Affection, also known as altruism, is the care and concern for others and their wellbeing. Control is defined by personal growth, competence, and influence over others. Inclusion refers to the need to belong and need for individuation (or uniqueness). Individuation and affection were shown to be motivational factors for forwarding online information (Ho and Dempsey 2010). The need for control and rate of Internet content consumption were also associated with forwarding online content (Ho and Dempsey 2010).

\section{Email Marketing and Electronic Word of Mouth}

Email marketing has been recognized as a communication method that allows for building relationships with customers (Jackson and DeCormier 1999). With the availability of advanced technology to collect data about consumers, emails to customers can be easily 
personalized, targeted, and tracked. Expenses for email marketing campaigns are low, and allow organizations to reach many individuals (SMBmarketer.com Announces 2010). Customers' response rates to emails are high, which makes it even more attractive to marketers (Di Ianni 2000; Rosenspan 2000). Furthermore, technological innovations, such as graphics, audio, and video email, allow companies to create improved emails and possibly enhance consumers' receptiveness to messages.

With continual developments in software applications and mobile devices, consumers are using additional methods for communication. This leads some to believe that email is now an outdated form of electronic communication. Despite some anecdotes about email being passé, email reaches about 3.6 billion people, which is three times more than Facebook and Twitter combined (Lee 2014). How consumers access their emails and respond to emails has progressed, and marketers must heed these changes. About $50 \%$ of individuals only interact with email on mobile devices, which includes smart phones and tablets (Yesmail Study 2014). This type of interaction has the advantage of the mobility of electronic devices making it convenient for consumers to read and pass along emails. A disadvantage is that companies must consider how to develop emails that are attractive and viewable on a variety of screen sizes. With the advancements in technology and Wi-Fi connectivity, consumers can effortlessly access, read, and forward emails (from marketers) to their friends, family, and co-workers. This highlights the importance of email marketing, and how it can lead to E-WOM.

Researchers have studied emails, both in the context of email marketing and E-WOM. Email frequency of exposure, demographic characteristics of consumers, message content, advertising value, and attitude towards email advertising were investigated for Indian consumers (ul Haq 2009). Consumers are not receptive towards unsolicited emails (Mehta and Sivadas 
1995), and both academics and practitioners have expressed concern regarding permission marketing. This means the individual must give consent or request the email communications. Kent and Brandal (2003) suggest that firms must consider the response rate, as well as the range of different consumer responses, to successfully engage individuals using email marketing. An admediary, a third party that facilitates email communication between sellers and potential customers, enhances value for both the business and consumer by increasing benefits (Gopal, Tripathi, and Walter 2006).

Based on consumer responses and motivations for passing along emails, Phelps et al. (2004) identified viral mavens, which are consumers who receive and forward many email messages. Opportunities are available for companies to capitalize on infrequent senders, especially those who receive few emails, but forward a high percentage of received emails (Phelps et al. 2004). This is a desirable target market for businesses hoping to generate E-WOM.

Factors associated with forwarding intentions of emails include message involvement, social interaction tie, affection outcome expectation, and perceived self-efficacy of message passing (Huang, Lin, and Lin 2009). Using communication, consumer value, personality, WOM, and source credibility theories, Chiu et al. (2007) found that message source, utilitarian and hedonic content of the message, and sender personality traits impacted E-WOM behavioral intentions. Gender plays a role in evaluating promotional email messages; females are more concerned with privacy issues when compared to males (Phillip and Suri 2004). Pavlov, Melville, and Plice (2008) argued that spam, i.e., unwanted commercial emails, should be analyzed as part of the entire email marketing infrastructure. Attitude towards a firm's email campaign is positively related to purchase intentions (Cases et al. 2010). Firms should consider 
more customized emails with better price personalization for customers to decrease competition based solely on price, which leads to profit growth (Chen and Sudhir 2004).

\section{Social Networking Sites}

E-WOM may be disseminated in a variety of ways, including social networking sites. Social networking sites are any websites that allow users to create profiles on the website and form relationships with other users of the same website. Social connections are often displayed on these sites, and some offer additional services. Some social networking sites allow groups, organizations, and even companies to create profiles. The connections and interactions available through social networking sites are appealing to individuals (Boyd and Ellison 2007). Examples of social networking sites include Facebook, LinkedIn, and Pinterest. As of June 2014, Facebook is the most popular social networking site with approximately 900 million unique visitors each month (The Top 2014).

In recent years, the popularity of social networking sites has grown substantially. Seventy-three percent of online adults use social networking sites (Social Networking 2013). With the ubiquity of mobile devices and Wi-Fi connectivity, it is even more convenient to connect on social networking sites. Almost $40 \%$ of mobile phone users access social networking sites via smart phones (Social Networking 2013). Some individuals use social networking sites to keep in touch with current, real-life friends online. Others utilize social networking sites to make new friends who may share similar interests and activities. Some consumers even connect on social networking sites due to companies and organizations; users look for other customers' opinions and insights on brands, products, and services. 
Previous research on social networking sites varies in theoretical frameworks and methodologies. Using Third-Person Effect Theory from the communications discipline, Zhang and Daugherty (2009) investigated how young consumers ego-defensiveness may be used to marketers’ advantage in stimulating E-WOM on social networking sites. EWOM through Twitter, a microblog form of social networking, influences brand awareness and image, which companies should monitor and use to their advantage (Jansen et al. 2009). Rather than targeting opinion leaders of online discussion groups on social networks, companies should strategize with contests and sweepstakes aimed towards all members of these online groups (Steyer, GarciaBardidia, and Quester 2006). Instead of simply using the push strategy, marketers should embrace social network users as co-creators of value (Vargo and Lusch 2004), empower consumers by listening to them and creating special programs (Miller and Lammas 2010), and avoiding messages that infringe on the socialization aspect of these sites and abuse consumers’ trust (Angel and Sexsmith 2011).

Trusov, Bucklin, and Pauwels (2009) found that E-WOM referrals for joining a social networking site were more effective than traditional marketing efforts to recruit new individuals; this referral effect of E-WOM may be particularly useful in the customer acquisition process. Companies should view opinion leaders as knowledgeable helpers in the viral marketing process, rather than direct agents. Potential influencers will reject blatant attempts to persuade users to promote the brand or market offering, which defeats the purpose of attempting to engender EWOM (Subramani and Rajagopalan 2003). Firms must tread carefully in their efforts to encourage E-WOM behavior.

Much research has been conducted on both emails and social networking sites as methods for E-WOM. Some studies investigated the phenomena of interest using general consumers and 
self-reported perceptions (Huang, Lin, and Lin 2009; Mowen, Park, and Zablah 2007; Phelps et al. 2004; Tran, Strutton, and Taylor 2012; Zhang and Daugherty 2009). Few studies have used customer data pertaining to one e-tailer to study E-WOM (Cases et al. 2010; Trusov, Bucklin, and Pauwels 2009). However, there is still a gap in the literature regarding e-servicescape, emails, and social networking sites. This dissertation will investigate these relationships using customer data for one specific e-tailer, which will have both theoretical and managerial contributions.

\section{Customer Loyalty}

Oliver defined customer loyalty as "a deeply held commitment to rebuy or re-patronize a preferred product/service consistently in the future, thereby causing repetitive same-brand or same brand-set purchasing, despite situational influences and marketing efforts having the potential to cause switching behavior" (1997, p. 392). Loyalty is both a positive attitude towards the organization and commitment to re-purchasing in the future (Chan and Chu 2007). Simply satisfying customers is not enough to retain them as customers, or build loyalty. Despite expressing satisfaction with their vehicles, less than half of consumers purchase the same make or model for their next automobile (Reichheld 1996). High levels of satisfaction do not imply customers' commitment to re-purchase.

Customer loyalty can lead to profitably for firms (Hayes 2000) and loyal customers are important assets for organizations. Increased loyalty means additional purchases, and loyal customers are less likely to switch based on competitive prices (Bowen and Shoemaker 1998). Keeping current customers is less expensive than acquiring new ones (Hayes 2008). The cost of new online customer acquisition could mean an unprofitable customer relationship for up to 
three years (Reichheld, Markey, and Hopton 2000). Firms may also capitalize on loyal customers by convincing them to buy more and boosting revenue. Furthermore, companies can motivate loyal customers to engage in WOM (Keiningham et al. 2008) and E-WOM.

Trust in e-tailers positively affects loyalty and trust can be encouraged by providing a reliable, secure, and reassuring website (Ribbink et al. 2004). Process value and satisfaction are significantly related to loyalty for online shoppers, but shopping enjoyment and outcome value were not associated with loyalty (Shun and Yunjie 2006). Anderson and Srinivasan (2003) assessed convenience motivation, purchase amount, and inertia as moderators of the online satisfaction and loyalty relationship. For online vendors, trust and satisfaction are both positively related to loyalty; antecedents of trust and satisfaction are reliability and website design (Kim, Jin, and Swinney 2009).

\section{Purchase Intentions}

Simply put, purchase intention is the likelihood that an individual will buy a market offering (Morrison 1979). Generally, purchase intentions result from perceptions of need and want, perceptions of the marketing offering, interactions or observations regarding the product or service, and/or perceptions of the company. E-tailers face the challenge of gaining consumers' trust before they actually convert to customers. Buying online requires individuals to share detailed information, which triggers privacy and security concerns.

Prior online purchasing experience, trust, and impulse purchase orientation influence stated purchase intentions (Thamizhvanan and Xavier 2013). Trust and risk play crucial roles when it comes to online transactions (Pavlou 2003). Trust in the e-vendor is a prerequisite for consumers to buy from the e-vendor (McCole 2002). Perceived website quality impacts trust, 
which in turn influences intent to buy from that website (Everard and Galletta 2006). Van der Heijden, Verhagen, and Creemers (2003) studied purchase intentions from both trust and technology perspectives and found that perceived risk and perceived ease of use influenced the attitude towards online purchase intentions. As previously mentioned, trust is composed of ability, benevolence, and integrity. Compared to benevolence and integrity, the ability component of trust impacted online buying intentions more (Schlosser, White, and Lloyd 2006). Satisfaction with the website, trust in the website, and awareness of the website impacted individuals’ online purchase intentions (Yoon 2002).

Many researchers have investigated customer loyalty and purchase intentions, both in the context of brick-and-mortar and online stores. However, the relationships between online servicescape, trust, E-WOM (in the form of emails and social network postings), customer loyalty, and purchase intentions have been not studied. Toward this end, the present research integrates these constructs into a comprehensive model. This is an understudied area, particularly in the context of a single e-tailer with customer data. This dissertation intends to fill this gap and investigate these relationships.

\section{Theoretical Framework}

\section{Commitment-Trust Theory of Relationship Marketing}

The commitment-trust theory of relationship marketing is based on relationship commitment and trust as the key mediating variables (Morgan and Hunt 1994). The antecedents of the model include shared values, communication, opportunistic behavior, relationship benefits, relationship termination costs, and legalities. The outcome factors are financial performance, cooperation, functional conflict, decision-making uncertainty, propensity to leave, 
and acquiescence. This theory is believed to be "the foundations of a marketing relationship that can lead to customer retention” (Veloutsou, Saren, and Tzokas 2002). Commitment-trust theory of relationship marketing has been applied to both business-to-business and business-toconsumer contexts (Delgado-Ballester and Munuera-Aleman 2001); Doney and Cannon 1997; Gounaris 2005; Mukherjee and Nath 2007). Although the present study incorporates trust as part of the research model, the commitment-trust theory of relationship marketing encompasses additional antecedent and outcome variables that are not part of the investigation. Therefore, this theory is not suitable to support this research.

\section{Socialization Theory}

Another theoretical perspective considered for this study is socialization theory. This theory suggests that the processes by which young individuals acquire skills, knowledge, and attitudes are relevant to how they function as consumers in the marketplace (Ward 1974). This theory is related to Piaget's theory of intellectual development, also known as the cognitive development approach to socialization. As individuals grow up and mature, the consumer socialization process happens in a social context, which includes the family, peers, media, and information from marketers (John 1999; Moschis 1981). When parents negotiate their children's purchase requests, allocate weekly allowances, and take their children on shopping trips, they are creating opportunities for consumer socialization for their children (Ward, Wackman, and Wartella 1977). Peers also influence individuals, starting early in life. Mass media and advertisements present information about goods, services, and the material value of these goods and services (Martin and Gentry 1997; Robertson, Rossiter, and Gleason 1979). Socialization Theory was evaluated as an alternative theoretical basis; however, it was deemed ill-fitting. This 
dissertation investigates E-WOM intentions in a popular social networking site but does not account for the social aspect of the relationships.

\section{Stimulus-Organism-Response (SOR) Theory}

Originally developed in the environmental psychology discipline, stimulus-organismresponse (SOR) theory posits that the environment is the stimulus, which influences the organism and the organism's internal reactions, which then leads to behavioral responses (Mehrabian and Russell 1974) (see Figure 1). The organism’s internal reactions include both affective and cognitive elements. These emotions and cognitive beliefs mediate the approach (or avoidance) responses toward the environment (Mehrabian and Russell 1974). Researchers have applied SOR theory as the theoretical framework for understanding servicescape (Bitner 1992; Chebat and Michon 2003; Donovan and Rossiter 1982) and online servicescape (Ha and Lennon 2010; Kim, Fiore, and Lee 2007; Richard et al. 2009) to explain consumer behavior in the store environment. The stimulus is the physical evidence of a brick-and-mortar store. Customers react internally to the various stimuli, which then directly affects their behavioral responses. Similarly for e-servicescape, the stimuli are the website environment and service factors. Kim and Lennon (2013) investigated reputation and website quality as the stimuli, cognition and emotion as the organism, and purchase intentions as the response and found that reputation influenced individuals' emotions. The SOR model has also been used to research website characteristics, consumers’ emotional responses, and buying behavior (Mummalaneni 2005). This research is grounded in the SOR theoretical framework, where e-servicescape is the stimulus, trust is the customer's internal reaction, and response behaviors include purchase intentions, loyalty, and EWOM intentions. 


\section{FIGURE 1}

\section{Stimulus-Organism-Response Model}

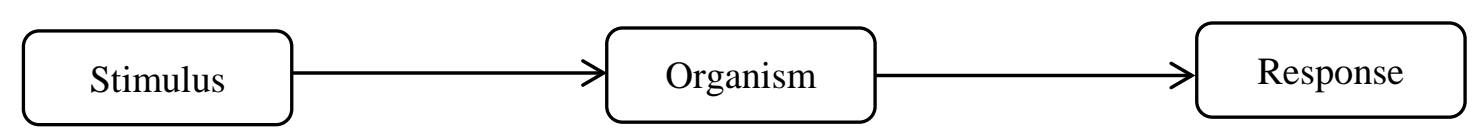

Organic Inter-Consumer Influence Model (OIIM)

One of the earliest models depicting WOM behavior, the organic inter-consumer influence model (OIIM) shows how consumers interact with other consumers and share information about their experiences (Kozinets et al. 2010). Individuals participate in these conversations without any direct influence from marketers. Generally, people engage in these interactions because of their desire to share their personal experiences, help others by warning them about mediocre products or services, and/or to show their status (Arndt 1967; Engel, Kegerreis, and Blackwell 1969; Gatignon and Robertson 1986). While the OIIM demonstrates the flow of information between consumers, the theoretical framework is not appropriate for the present research because it does not include influence from marketers.

\section{Linear Marketer Influence Model (LMIM)}

Another model describing WOM behavior is the linear marketer influence model (LMIM) (Kozinets et al. 2010), which stresses the importance of recruiting individuals with influential power (Feick and Price 1987; King and Summers 1976). As the opinion leaders of their social networks, these consumers forward favorable information about specific brands, stores, products, and services to many other consumers (Balter 2005). The WOM information originated from marketers in the form of advertising and promotional material. The linear aspect 
of this model stems from consumers' one-way dissemination of WOM communications. Due to this linearity of information flow, the LMIM is not suitable for this research study.

\section{Network Co-Production Model (NCPM)}

E-WOM involves consumers as active co-producers of information (Vargo and Lusch 2004). When an individual passes along a message from a marketer, he or she embeds inherent value and meaning in the message during the E-WOM process. The network co-production model (NCPM) depicts the multi-directional flow of information, starting with the seeding from the marketer as the direct influence (see Figure 2).

\section{FIGURE 2}

\section{Network Co-Production Model}

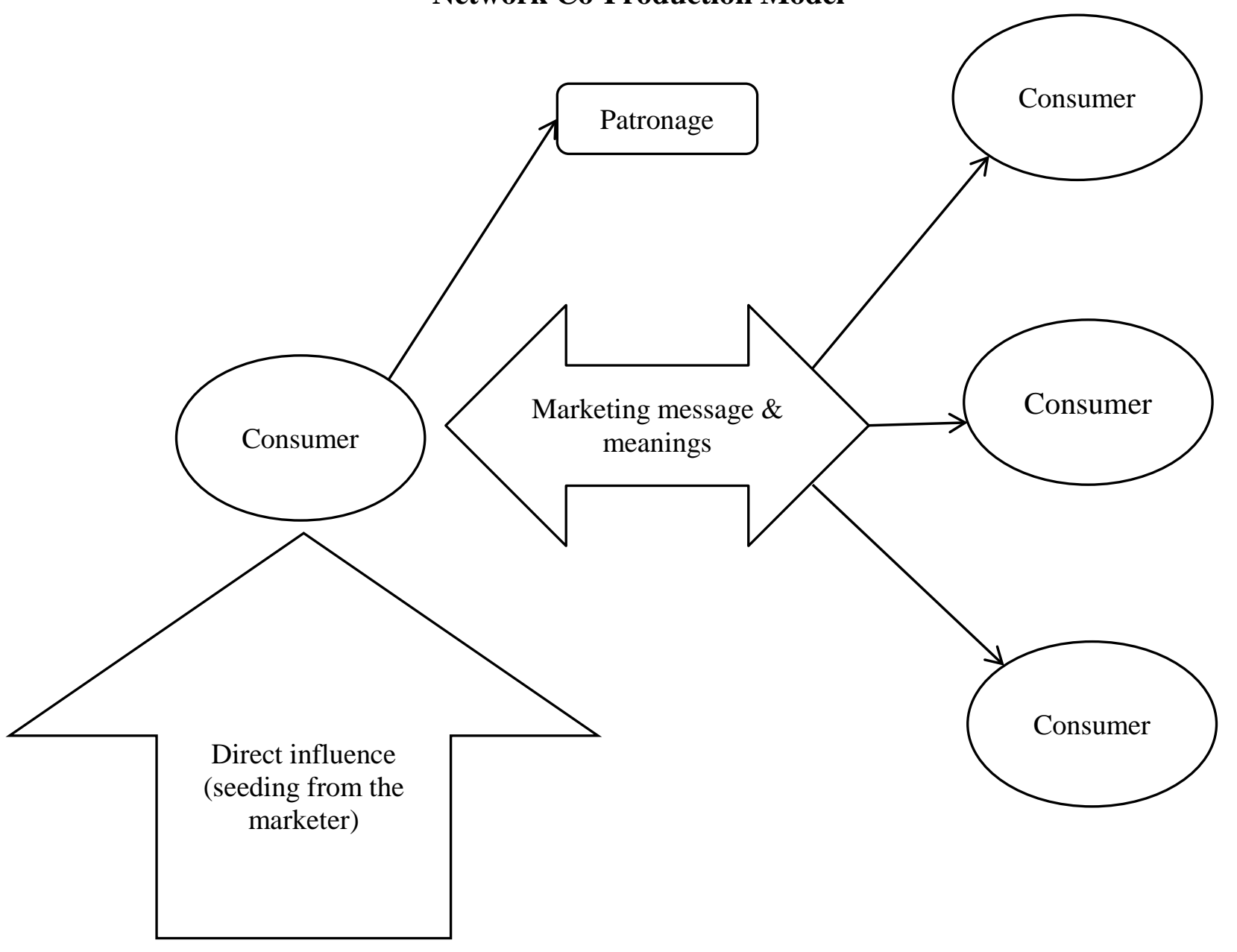


This seeding is conveyed to a select group of consumers. The role of consumers in networks, groups, and communities has grown significantly (Cova and Cova 2002; Muniz and O’Guinn 2001). The individuals then forward the seeded message to other consumers in their networks, adding their own value in the process. The receivers of E-WOM communications may respond to the sender and add their own meaning. Marketers recognize the potential value of consumers as effective co-producers, and are attempting to manage the E-WOM process (Brown, Broderick, and Lee 2007). Marketers are using different strategies and metrics to directly influence individuals and better understand the power of E-WOM. Due to both the interactive nature of the E-WOM activity depicted in the NCPM and the seeding from the marketer as direct influence, this theoretical model is deemed appropriate to support the present research.

\section{Model and Hypotheses Development}

As described in the previous sections, website characteristics can influence the customer, with e-servicescape as the stimulus and the customer's internal reaction of trust as the organism of SOR theory. In turn, the trust likely influences behavioral responses, including E-WOM intentions, customer loyalty, and purchase intentions behavior. These relationships are encapsulated in the research model shown in Figure 3. Thus, it is hypothesized that:

H1 (a-j): E-servicescape is positively related to the website's (a) visual appeal, (b) entertainment value, (c) originality of design, (d) customer reviews, (e) customization, (f) interactivity, (g) relevance of information, (h) usability, (i) ease of payment, and (j) perceived security.

H2: E-servicescape is positively related to consumer trust in the website.

H3: Trust is positively related to the likelihood of engaging in E-WOM behavior.

H4: Trust is positively related to customer loyalty.

H5: Trust is positively related to purchase intentions. 


\section{FIGURE 3 \\ Research Model}

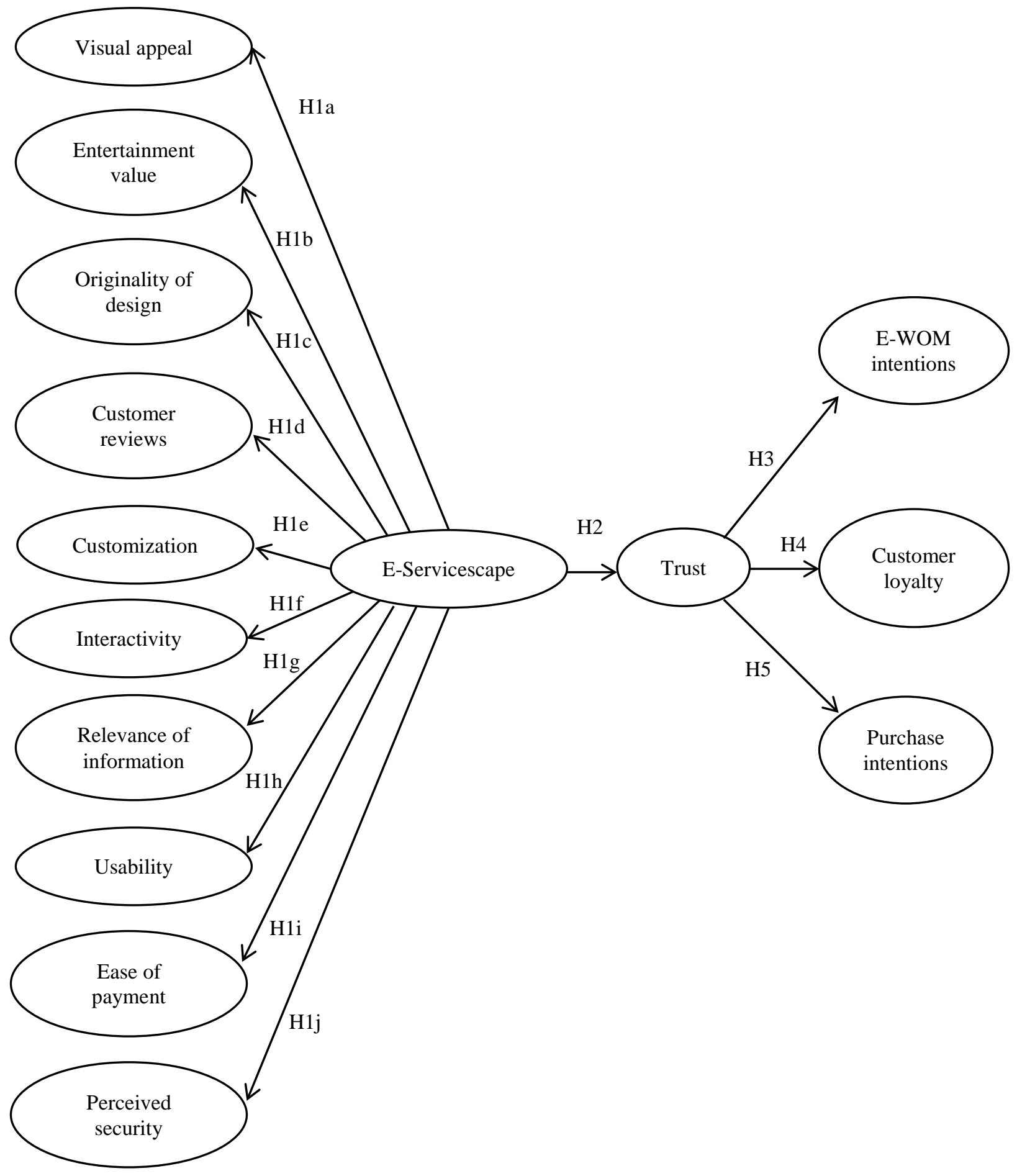


In addition to SOR theory, the research model is also supported by the network coproduction model. For this research study, the direct seeding from the marketer happens in two forms of electronic communication: email and social network posting. The e-tailer intends for customers to make purchases. Besides patronage from the original receiver of the electronic message, the e-tailer also hopes he or she will forward the communication to other consumers and embed their own meaning and value in the E-WOM process. There is potential for multidirectional flows of information when consumers generate conversations about the e-tailer. There is also the likelihood of consumers reading online customer reviews, which is another form of EWOM, which is another part of the multi-directional flow of information.

As described in previous sections, emails are still an important tool in the marketer's toolbox. Although some are quick to abandon it as an outdated form of electronic communication, companies should still use emails as a part of their direct marketing program. Many consumers currently use email (Lee 2014) and want to receive emails from e-tailers. As a form of direct marketing, email campaigns are inexpensive and useful for acquiring new customers and reminding current customers of the market offerings. When consumers provide information to companies and agree to receive emails, companies can capitalize on opportunities to make marketing campaigns more efficient and effective through customization (Godin 1999). In addition, emails reach more consumers than social network postings, including Facebook (Lee 2014). Based on this rationale, it is hypothesized that:

H6 (a-j): Compared to social network postings recipients, email recipients will have more positive perceptions of e-servicescape, including the website's (a) visual appeal, (b) entertainment value, (c) originality of design, (d) customer reviews, (e) customization, (f) interactivity, (g) relevance of information, (h) usability, (i) ease of payment, and (j) perceived security.

H7: Compared to social network postings recipients, email recipients will have greater trust in the website. 
H8: Compared to social network postings recipients, email recipients will be more likely to engage in E-WOM behavior.

H9: Compared to social network postings recipients, email recipients will have higher customer loyalty.

H10: Compared to social network postings recipients, email recipients will have higher purchase intentions. 


\section{CHAPTER 3}

\section{METHODOLOGY}

\section{Overview}

This study uses cross-sectional customer data from a single apparel retailer, The Territory Ahead, to investigate hypothesized relationships between online servicescape, trust, E-WOM intentions, loyalty, and purchase intentions. Precedence has been established for the use of single-firm data in prior research studies (Cases et al. 2010; Harris 1990; Mahajan et al. 1984; Newman et al. 2010; Spreitzer 1996). Originally, the clothing company started as a catalog retailer. For a period of time, the company operated a handful of brick-and-mortar stores on the Pacific coast. These store locations were closed in 2012. Currently, the firm offers both men’s and women's clothing, shoes, and accessories through direct mail catalogs and a retail website. The retailer caters to consumers who desire high quality, durable, and casual apparel and accessories. The majority of the company’s sales are realized via its website, making this e-tailer an appropriate firm for testing the hypothesized relationships. Since the company does not have many brick-and-mortar stores, there is little chance of customers' confounding the physical store servicescape with the e-servicescape.

\section{Sampling Procedure}

The data were collected through a nationwide survey offered online through Qualtrics. For two weeks, customers of the e-tailer were invited to complete the survey in exchange for a $20 \%$ discount off their next purchase. The company offered access to the survey questionnaire link via both email and Facebook posting. The questionnaire was identical for both groups of 
respondents, with the exception of E-WOM scale items adapted for the particular form of communication (i.e., email or Facebook posting).

For the constructs of interest, the survey questionnaire was programmed to rule out the possibility of missing values. To decrease the chance of question order bias, questions were randomized within each block. Each block of questions focused on a construct, or sub-dimension of a construct. The demographic and open-ended questions were optional, and some respondents chose not to complete these questions.

About 10,000 customers were invited to participate in the survey via emails and Facebook postings. One thousand one hundred forty-two customers started the survey, and 613 respondents completed the entire survey, with a completion rate of almost 54\%. The high incompletion rate is likely due to the length of the questionnaire. The overall response rate for completed surveys was 6\%. Fifty-three percent of respondents accessed the survey link from a Facebook posting and 47\% through an email link. Forty-nine percent of the respondents were female. Approximately 75\% were between the ages of 50 and 69 years and the mean age was 56 years. Sixty-six percent of the respondents were married. Eighty-one percent earned college degrees, pursued some graduate education, or completed graduate degrees. Forty-three percent of respondents reported total annual household incomes of $\$ 100,000$ or greater and the mean household income was nearly $\$ 133,000$. The mean annual expenditure on apparel and accessories was a little over $\$ 2,000$. Sixty-nine percent reside in small households of one to two people. The complete demographic statistics of the sample are provided in Table 1.

TABLE 1 Demographic Profile of Respondents

\begin{tabular}{clrr}
\hline Measure & Value & Frequency & Frequency \% \\
\hline Communication method & Email & 288 & $47 \%$ \\
& Social network site & 325 & $53 \%$
\end{tabular}




\begin{tabular}{llrr}
\hline \multicolumn{1}{c}{ Measure } & \multicolumn{1}{c}{ Value } & Frequency & Frequency \% \\
\hline Gender & Female & 302 & $49 \%$ \\
& Male & 306 & $50 \%$ \\
& Did not provide & 5 & $1 \%$ \\
Age & & 9 & $1 \%$ \\
& 30 or under & 10 & $2 \%$ \\
& $31-39$ & 109 & $18 \%$ \\
& $40-49$ & 292 & $48 \%$ \\
& $50-59$ & 168 & $27 \%$ \\
& $60-69$ & 14 & $2 \%$ \\
Race & 70 or over & 11 & $2 \%$ \\
& Did not provide & & $1 \%$ \\
& American Indian & 4 & $1 \%$ \\
Asian & 5 & $1 \%$ \\
& Black or African American & 11 & $2 \%$ \\
Hispanic or Latino & 3 & $0 \%$ \\
& Indian & 9 & $1 \%$ \\
Mixed race & & $0 \%$ \\
& Native Hawaiian or Pacific & 2 & $81 \%$ \\
& Islander & 499 & $12 \%$
\end{tabular}

Highest level of education

Some high school or less

High school graduate

Some college education

College graduate

Some graduate education

Graduate degree

$\begin{array}{rr}3 & 0 \% \\ 21 & 3 \% \\ 98 & 16 \% \\ 169 & 28 \% \\ 59 & 10 \% \\ 263 & 43 \% \\ & \\ 47 & 8 \% \\ 109 & 18 \% \\ 193 & 31 \% \\ 60 & 10 \% \\ 15 & 2 \% \\ 189 & 31 \%\end{array}$

Marital status

under $\$ 50,000$

$8 \%$

$\$ 50,000-99,999$

$18 \%$

\$100,000-199,999

$31 \%$

\$200,000-299,999

$2 \%$

Did not provide

Single
Married
Living with a partner
Separated
Widowed
Divorced
Did not provide

Household size

$10 \%$

$407 \quad 66 \%$

$28 \quad 5 \%$

$2 \quad 0 \%$

$16 \quad 3 \%$

$47 \quad 8 \%$

$50 \quad 8 \%$

$102 \quad 17 \%$

$318 \quad 52 \%$

$94 \quad 15 \%$

$70 \quad 11 \%$ 


\begin{tabular}{llrr}
\hline Measure & Value & Frequency & Frequency \% \\
\hline 5 & 16 & $3 \%$ \\
6 & 6 & $1 \%$ \\
7 or more & 2 & $0 \%$ \\
& Did not provide & 5 & $1 \%$
\end{tabular}

Potential non-response bias was assessed by comparing early and late respondents using the linear extrapolation method (Armstrong and Overton 1977). This method is based on the assumption that late respondents are similar to non-respondents, as compared to early respondents. During the two weeks of data collection, customers were contacted twice via email and Facebook posting. Individuals who completed the survey during the first week after the initial contact were the wave one respondents. Wave two respondents completed the questionnaire during the second week, after the reminder email and Facebook posting. First, demographic variables were compared for both waves. The chi-square tests indicated no statistically significant differences. Regarding demographic variables, the early and late respondents are similar. The details are provided in Table 2.

TABLE 2

Comparison of Early and Late Respondents on Demographic Variables

\begin{tabular}{lrrr}
\hline \multicolumn{1}{c}{ Variable } & Chi-square & $\boldsymbol{d} \boldsymbol{f}$ & p-value \\
\hline Age & 8.074 & 5 & 0.152 \\
Education & 4.814 & 5 & 0.439 \\
Gender & 4.258 & 3 & 0.128 \\
Household size & 5.369 & 6 & 0.497 \\
Income & 3.491 & 4 & 0.479 \\
Marital status & 6.677 & 6 & 0.352 \\
Race & 11.524 & 8 & 0.174 \\
\hline
\end{tabular}

The next step was to compare the two waves of respondents on key constructs. For the purposes of assessing potential non-response bias, each sub-dimension of online servicescape was considered as a key construct (i.e., visual appeal, customization, perceived security, etc.). No statistically significant differences were detected. For the key constructs, early and late 
respondents are similar. The analysis of variance results are presented in Table 3. Based on the wave analysis, non-response bias was not a concern for this study.

TABLE 3

Comparison of Early and Late Respondents on Key Constructs

\begin{tabular}{lcrrr}
\hline \multicolumn{1}{c}{ Construct } & F & $\begin{array}{c}\boldsymbol{d} \boldsymbol{f} \\
\text { (between groups) }\end{array}$ & $\begin{array}{c}\boldsymbol{d} \boldsymbol{\text { f }} \\
\text { (within groups) }\end{array}$ & $\boldsymbol{p}$-value \\
\hline Entertainment Value & 1.024 & 1 & 611 & 0.312 \\
Originality of Design & 0.167 & 1 & 611 & 0.683 \\
Visual Appeal & 2.496 & 1 & 611 & 0.115 \\
Customer Reviews & 0.709 & 1 & 611 & 0.592 \\
Customization & 1.570 & 1 & 611 & 0.211 \\
Interactivity & 0.860 & 1 & 611 & 0.264 \\
Relevance of Information & 1.704 & 1 & 611 & 0.192 \\
Usability & 0.036 & 1 & 611 & 0.849 \\
Ease of Payment & 0.541 & 1 & 611 & 0.462 \\
Perceived Security & 0.277 & 1 & 611 & 0.599 \\
Trust & 2.026 & 1 & 611 & 0.155 \\
E-WOM Intentions & 2.321 & 1 & 611 & 0.267 \\
Customer Loyalty & 1.821 & 1 & 611 & 0.178 \\
Purchase Intentions & 0.006 & 1 & 611 & 0.941 \\
\hline
\end{tabular}

\section{Measures}

Most constructs were measured with items adapted from previously developed and validated scales. For online servicescape, measurement items were adapted from Harris and Goode (2010). As mentioned previously, e-servicescape has three dimensions: aesthetic appeal, layout and functionality, and financial security.

\section{Aesthetic Appeal}

Aesthetic appeal was assessed through three sub-dimensions, including entertainment value, originality of design, and visual appeal. A sample survey measure for entertainment value included “it is fun shopping on ___ 's (e-tailer) website even when I do not make a purchase.” For originality of design, a sample item was "the design of this website is fresh and original.” An 
example of a measure for visual appeal was "the way 's (e-tailer) website displays products

is attractive.” In total, 11 scale items were used to measure the aesthetic appeal dimension (presented in Table 4).

TABLE 4

Items for Aesthetic Appeal Dimension of E-Servicescape

\begin{tabular}{|c|c|}
\hline Sub-dimension & Item \\
\hline \multirow[t]{3}{*}{ Entertainment Value } & I find this website entertaining \\
\hline & The enthusiasm displayed on this website lifts my spirits \\
\hline & It is fun shopping on ___ 's (e-tailer) website even when I do not make a purchase \\
\hline \multirow[t]{4}{*}{ Originality } & The ___ 's (e-tailer) website features a traditional design* \\
\hline & The design of this website is pretty much like the design of other websites I shop from* \\
\hline & The design of the ____ 's (e-tailer) website is fresh and original \\
\hline & The ___ 's (e-tailer) website is unadventurous* \\
\hline \multirow{4}{*}{ Visual Appeal } & This website is aesthetically appealing \\
\hline & The way ___ 's (e-tailer) website displays products is attractive \\
\hline & I like the look of ___ 's (e-tailer) website \\
\hline & The ___ 's (e-tailer) website does not use visually appealing graphics* \\
\hline
\end{tabular}

*Reverse-coded item.

\section{Layout and Functionality}

Layout and functionality featured four sub-dimensions from the original scale: customization/personalization, interactivity, relevance of information, and usability (Harris and Goode 2010). A sample survey item for customization included "the services of this website are often personalized to my needs.” For interactivity, five items were used to measure this subdimension, such as "this website does not let me view merchandise in different ways.” To measure relevance of information, an item included was "all relevant information is easily available on this website.” A sample scale item for usability was “___ 's (e-tailer) website offers quality keyword search functionality.” As a fifth sub-dimension of layout and functionality, two scale items measuring customer reviews were developed specifically for this study. Consumers appreciate the user-generated reviews, and increasingly rely on this 
information to make purchase decisions (Purchase Decisions 2013). Thus, it was deemed

important to create the sub-dimension customer reviews for the e-servicescape scale. The two

items for customer reviews were "I like to read customer reviews on ___ _s (e-tailer) website"

and "customer reviews are helpful when I make purchase decisions on ____s (e-tailer)

website.” A total of 19 items were included to measure layout and functionality. All

measurement items for this dimension of online servicescape are provided in Table 5.

TABLE 5

Items for Layout and Functionality Dimension of E-Servicescape

\begin{tabular}{|c|c|}
\hline Sub-dimension & Item \\
\hline Customer Reviews & $\begin{array}{l}\text { Customer reviews are helpful when I make purchase decisions on ___ 's (e-tailer) website } \\
\text { I like to read customer reviews on ___ 's (e-tailer) website }\end{array}$ \\
\hline Customization & $\begin{array}{l}\text { This website is laid out to satisfy my needs } \\
\text { The services of this website are often personalized to my needs } \\
\text { This website treats me like an individual } \\
\quad \text { 's (e-tailer) website does not make purchase recommendations that match my needs* }\end{array}$ \\
\hline Interactivity & $\begin{array}{l}\text { This website helps me compare products } \\
\text { The _e-tailer) website helps me compare prices } \\
\text { This website does not let me view merchandise in different ways* } \\
\text { This website has a search tool which helps me find exactly what I want } \\
\text { The ___ (e-tailer) website does not engage me* }\end{array}$ \\
\hline $\begin{array}{l}\text { Relevance of } \\
\text { Information }\end{array}$ & $\begin{array}{l}\text { All relevant information is easily available on this website } \\
\text { Technical details about the items can be easily accessed easily when browsing this website } \\
\text { Each page on the website clearly indicates what one can expect to find }\end{array}$ \\
\hline Usability & $\begin{array}{l}\text { Finding the exact items I want on __ 's (e-tailer) website is difficult* } \\
\text { 's (e-tailer) website is difficult to use* } \\
\text { The navigational aids on this website are useful } \\
\text { There are convenient ways to maneuver among various pages (shirts to pants) on this } \\
\text { website } \\
\text { 's (e-tailer) website offers quality keyword search functionality }\end{array}$ \\
\hline
\end{tabular}

*Reverse-coded item.

Financial Security

Financial security was composed of two dimensions: ease of payment and perceived security (Harris and Goode 2010). Seven items were included to measure financial security. To 
measure customers’ perceived ease of payment, measures such as “___s (e-tailer) online payment process is reasonable” were included. A sample item for the perceived security subdimension was "the security systems of this website appear rigorous.” The items are listed in Table 6.

\section{TABLE 6}

Items for Financial Security Dimension of E-Servicescape

\begin{tabular}{ll}
\hline \multicolumn{1}{c}{ Sub-dimension } & \multicolumn{1}{c}{ Item } \\
\hline Ease of Payment & $\begin{array}{l}\text { On__s (e-tailer) website, paying for items involves entering too many details* } \\
\text { Payment procedures take a long time to complete on this website* }\end{array}$ \\
\cline { 2 - 2 } $\begin{array}{l}\text { Paying for (e-tailer) online payment process is reasonable } \\
\text { Perceived Security }\end{array}$ & $\begin{array}{l}\text { The security systems of this website appear rigorous } \\
\text { Overall,___s (e-tailer) website appears to be security conscious } \\
\text { I have no security concerns when I purchase apparel and accessories from this website }\end{array}$ \\
\hline *Reverse-coded item. &
\end{tabular}

Trust

To measure trust, five items were adapted from Harris and Goode’s scale (2010). Sample items for trust were "overall, I feel that I can trust this website" and "few limits exist on how far this company will go to solve my website services problems.” A five-point Likert-type scale was used for the items, where 1 indicated "strongly disagree” and 5 indicated "strongly agree." The scale items for trust are presented in Table 7.

\begin{tabular}{|c|}
\hline $\begin{array}{c}\text { TABLE } 7 \\
\text { Items for Trust }\end{array}$ \\
\hline Item \\
\hline _'s (e-tailer) website seems genuinely committed to my satisfaction \\
\hline Overall, I trust this website \\
\hline In terms of usability, I know what to expect from ___ 's (e-tailer) website \\
\hline If ___ (e-tailer) makes a claim about its product, it is probably true \\
\hline Few limits exist on how far ___ will go to solve my website service problems \\
\hline
\end{tabular}




\section{Electronic Word of Mouth}

For E-WOM intentions, items were adapted from other research studies (Okazaki 2009; Verhoef, Franses, and Hoekstra 2002). A sample measure for E-WOM included “were I to receive an interesting email from this company, I would forward it to my friends and family.” All three E-WOM measures were adapted to reflect the specific form of electronic communication for respondents, email or Facebook posting. Again, a five-point Likert-type scale was used, where 1 indicated "never” and 5 indicated "always.” E-WOM measurement items are included in the following table.

TABLE 8 Items for E-WOM Item

I would make recommendations to my friends and family about signing up for (emails/Facebook updates) from (e-tailer)

If someone asks me for advice about (emails/Facebook updates) from 's (e-tailer) website, I will encourage them to sign up for (e-tailer)

If I receive an interesting (email/Facebook posting) from to/for my friends and family (e-tailer), I would forward/repost it

\section{Purchase Intentions}

For purchase intentions, three measures were developed specifically for this study. Previously validated scales for purchase intentions were also considered. However, given that the e-tailer's products represent a variety of categories, the scales from the literature were deemed inappropriate for the questionnaire. A sample item for purchase intentions was "I expect to do more business with this website during the new few months.” Again, a five-point Likert-type scale was used, anchored by 1 for “strongly disagree” and 5 for “strongly agree.” Purchase intentions measurement items are provided in Table 9. 
TABLE 9

Items for Purchase Intentions

Item

's (e-tailer) website is my first choice for apparel

I expect to do more business with 's (e-tailer) website during the next few months

I intend to purchase fewer goods from 's (e-tailer) website during the next few months*

\section{Customer Loyalty}

Three items were included to measure customer loyalty (Beatty et al. 1996). A sample item for customer loyalty was "I am loyal to (e-tailer's name).” One loyalty item was reversed, namely “I don’t think I'll shop again at ___ (e-tailer's name).” Similar to the other questionnaire statements, customers responded to these items based on a five-point Likert-type scale, where 1 indicated "strongly disagree” and 5 indicated "strongly agree.” Scale items for loyalty are presented in Table 10. Any negatively-phrased scales were reverse coded prior to statistical analyses to maintain content consistency.

TABLE 10

Items for Loyalty

\section{Item}

I am loyal to ___ (e-tailer)

I don't think I'll shop at ___ (e-tailer) again*

I prefer ___ 's (e-tailer) clothing and accessories over other apparel alternatives

*Reverse-coded item.

\section{Survey Instrument}

The survey questionnaire included 80 statements. As a reminder for respondents to consider this e-tailer specifically while completing the online survey, many scale items were adapted to reflect the e-tailer's name in the statement. Moreover, some scale items were adapted to improve the wording and make it easier for respondents to read and comprehend. 
Aside from the constructs of interest for this current research study, the senior management team of the e-tailer requested the addition of specific survey items for the company's market research team to analyze. For this purpose, measurement items for perceived value, quality, style, fit, fashion orientation, and shopping orientation were added to the survey. There were also optional, open-ended questions regarding customers' perceptions of the current quality versus past quality, opinions on customer reviews, fit and sizing of the apparel items, and favorite words to describe the e-tailer's brand. There was one question about membership in social networking communities. The final items were demographic questions, which were also optional (age, annual family household income, marital status, racial or ethnic identification, highest level of education, and number of people in the household). After the demographic questions, respondents were thanked for their participation, and asked to forward the survey link to any family and friends that they believe would be interested in providing feedback and receiving the $20 \%$ discount. 


\section{CHAPTER 4}

\section{EMPIRICAL ANALYSIS AND RESULTS}

\section{Overview}

To test the hypotheses and assess the fit of the proposed model to the data, reliability and validity were first assessed for the measurement scales (Churchill 1979; Gerbing and Anderson 1988). The next step was to assess the proposed model for fit and test the hypotheses using structural equation modeling. The final step was to split the data into groups, based on the form of electronic communication, and compare the two groups employing multi-group analysis. A detailed description of the data analysis and results follows.

\section{Measurement Validation}

The initial step in the data analysis was to assess construct reliability and validity for the measurement scales via the two-step procedure proposed by Gerbing and Anderson (1988). Exploratory factor analysis (EFA) was conducted using SPSS. Two separate EFAs were conducted: 1) one for online servicescape, as a second-order construct and 2) for the endogenous variables, including trust, E-WOM intentions, purchase intentions, and loyalty.

For online servicescape, the measurement items for two sub-dimensions of layout and functionality, namely customization and relevance of information, loaded together on a single factor. As shown in Table 4, there is overlap in the items. When information presented by the etailer is germane to that particular customer, the customer's perception of the website's level of customization increases. The Cronbach's alpha for this combined sub-dimension is .907 and the factor loadings indicate that these measures together form a distinct sub-dimension from the same domain. This sub-dimension was termed "relevance and customization." 
Interactivity, originality, and usability had items with low factor loadings (less than .5).

With the exception of originality, all sub-dimensions of online servicescape had acceptable reliability, with Cronbach’s alpha values that ranged from .737 to .909. The Cronbach’s alpha for originality was .649, which is less than the recommended value of .7 (Hair et al. 2006; Nunnally 1978). The complete results of this initial EFA are presented in Table 11.

TABLE 11

Measurement Model Evaluation: Initial EFA for E-Servicescape

\begin{tabular}{|c|c|c|c|c|}
\hline Construct & Item & Loading & Mean & SD \\
\hline $\begin{array}{l}\text { Relevance } \\
\text { and Customization } \\
\text { (RC) }\end{array}$ & $\begin{array}{l}\text { All relevant information is easily available on this } \\
\text { website }\end{array}$ & 0.792 & 3.870 & 0.857 \\
\hline $\begin{array}{l}\text { Cronbach's alpha }=0.907 \\
\text { Mean }=3.616\end{array}$ & $\begin{array}{l}\text { Technical details about the items can be easily accessed } \\
\text { easily when browsing this website }\end{array}$ & 0.780 & 3.780 & 0.889 \\
\hline \multirow{5}{*}{$\begin{array}{l}\text { SD }=0.690 \\
\text { Percentage of variance }= \\
34\end{array}$} & $\begin{array}{l}\text { Each page on the website clearly indicates what one can } \\
\text { expect to find }\end{array}$ & 0.706 & 3.960 & 0.787 \\
\hline & $\begin{array}{l}\text { The services of this website are often personalized to my } \\
\text { needs }\end{array}$ & 0.568 & 3.230 & 0.876 \\
\hline & This website is laid out to satisfy my needs & 0.557 & 3.830 & 0.819 \\
\hline & $\begin{array}{l}\text { 's (e-tailer) website does not make purchase } \\
\text { recommendations that match my needs* }\end{array}$ & 0.546 & 3.330 & 0.871 \\
\hline & This website treats me like an individual & 0.538 & 3.310 & 0.925 \\
\hline $\begin{array}{l}\text { Entertainment Value } \\
\text { (E) }\end{array}$ & I find this website entertaining & 0.822 & 3.200 & 0.990 \\
\hline $\begin{array}{l}\text { Cronbach's alpha }=0.876 \\
\text { Mean }=3.341\end{array}$ & The enthusiasm displayed on this website lifts my spirits & 0.805 & 3.170 & 0.993 \\
\hline $\begin{array}{l}\mathrm{SD}=0.831 \\
\text { Percentage of variance }= \\
9\end{array}$ & $\begin{array}{l}\text { It is fun shopping on } \\
\text { I do not make a purchase }\end{array}$ & 0.755 & 3.480 & 1.015 \\
\hline $\begin{array}{l}\text { Ease of Payment (EP) } \\
\text { Cronbach's alpha }=0.849\end{array}$ & $\begin{array}{l}\text { On __ 's (e-tailer) website, paying for items involves } \\
\text { entering too many details* }\end{array}$ & 0.809 & 3.760 & 0.930 \\
\hline $\begin{array}{l}\text { Mean }=3.916 \\
\mathrm{SD}=0.720\end{array}$ & $\begin{array}{l}\text { Payment procedures take a long time to complete on this } \\
\text { website* }\end{array}$ & 0.803 & 3.842 & 0.909 \\
\hline \multirow{2}{*}{$\begin{array}{l}\text { Percentage of variance }= \\
6\end{array}$} & __ 's (e-tailer) online payment process is reasonable & 0.725 & 3.980 & 0.838 \\
\hline & Paying for goods is straightforward on this website & 0.721 & 4.080 & 0.783 \\
\hline Visual Appeal (V) & This website is aesthetically appealing & 0.885 & 4.13 & 0.904 \\
\hline $\begin{array}{l}\text { Cronbach's alpha }=0.823 \\
\text { Mean }=4.136\end{array}$ & $\begin{array}{l}\text { The way ___ 's (e-tailer) website displays products is } \\
\text { attractive }\end{array}$ & 0.877 & 4.15 & 0.9 \\
\hline $\mathrm{SD}=0.857$ & _'s (e-tailer) website & 0.869 & 4.13 & 0.91 \\
\hline
\end{tabular}




\begin{tabular}{|c|c|c|c|c|}
\hline Construct & Item & Loading & Mean & SD \\
\hline Percentage of variance $=5$ & $\begin{array}{l}\text { The _o 's (e-tailer) website does not use visually } \\
\text { appealing graphics* }\end{array}$ & 0.652 & 4.082 & 1.076 \\
\hline Interactivity (I) & This website helps me compare products & 0.836 & 3.28 & 0.89 \\
\hline Cronbach's alpha $=0.775$ & The ___ (e-tailer) website helps me compare prices & 0.826 & 3.11 & 0.894 \\
\hline $\begin{array}{l}\text { Mean }=3.416 \\
\mathrm{SD}=0.692\end{array}$ & $\begin{array}{l}\text { This website does not let me view merchandise in } \\
\text { different ways* }\end{array}$ & 0.492 & 3.66 & 0.905 \\
\hline \multirow[t]{2}{*}{ Percentage of variance $=4$} & $\begin{array}{l}\text { This website has a search tool which helps me find } \\
\text { exactly what I want }\end{array}$ & 0.442 & 3.61 & 0.853 \\
\hline & The ___ (e-tailer) website does not engage me* & 0.441 & 3.734 & 0.929 \\
\hline $\begin{array}{l}\text { Usability }(\mathbf{U}) \\
\text { Cronbach's alpha }=0.793\end{array}$ & $\begin{array}{l}\text { Finding the exact items I want on ___ } \\
\text { website is difficult* }\end{array}$ & 0.746 & 4.042 & 0.976 \\
\hline Mean $=4.058$ & _'s (e-tailer) website is difficult to use* & 0.706 & 4.333 & 0.798 \\
\hline $\mathrm{SD}=0.714$ & The navigational aids on this website are useful & 0.588 & 3.8 & 0.875 \\
\hline \multirow[t]{2}{*}{ Percentage of variance $=4$} & $\begin{array}{l}\text { There are convenient ways to maneuver among various } \\
\text { pages (shirts to pants) on this website }\end{array}$ & 0.438 & 3.88 & 0.827 \\
\hline & $\begin{array}{l}\text { 's (e-tailer) website offers quality keyword search } \\
\text { functionality }\end{array}$ & 0.328 & 3.65 & 0.803 \\
\hline $\begin{array}{l}\text { Customer Reviews } \\
\text { (CREV) Cronbach's alpha } \\
=0.909\end{array}$ & $\begin{array}{l}\text { Customer reviews are helpful when I make purchase } \\
\text { decisions on ___ 's (e-tailer) website }\end{array}$ & 0.932 & 3.88 & 1.151 \\
\hline $\begin{array}{l}\text { Mean }=3.873 \\
\mathrm{SD}=1.114\end{array}$ & $\begin{array}{l}\text { I like to read customer reviews on ___ 's (e-tailer) } \\
\text { website }\end{array}$ & 0.929 & 3.86 & 1.177 \\
\hline \multicolumn{5}{|l|}{ Percentage of variance $=3$} \\
\hline Perceived Security (PS) & The security systems of this website appear rigorous & 0.786 & 3.52 & 0.937 \\
\hline $\begin{array}{l}\text { Cronbach's alpha }=.737 \\
\text { Mean }=3.810\end{array}$ & $\begin{array}{l}\text { Overall, ___ _s (e-tailer) website appears to be security } \\
\text { conscious }\end{array}$ & 0.738 & 3.93 & 0.751 \\
\hline $\begin{array}{l}\mathrm{SD}=.692 \\
\text { Percentage of variance }=3\end{array}$ & $\begin{array}{l}\text { I have no security concerns when I purchase apparel and } \\
\text { accessories from this website }\end{array}$ & 0.712 & 3.98 & 0.867 \\
\hline $\begin{array}{l}\text { Originality }(\mathbf{O}) \\
\text { Cronbach's alpha }=.649\end{array}$ & $\begin{array}{l}\text { The __ 's (e-tailer) website features a traditional } \\
\text { design* }\end{array}$ & 0.862 & 2.736 & 0.907 \\
\hline $\begin{array}{l}\text { Mean }=2.820 \\
\mathrm{SD}=2.820\end{array}$ & $\begin{array}{l}\text { The design of this website is pretty much like the design } \\
\text { of other websites I shop from* }\end{array}$ & 0.708 & 2.904 & 1.036 \\
\hline \multirow[t]{2}{*}{ Percentage of variance $=2$} & $\begin{array}{l}\text { The design of the ___ 's (e-tailer) website is fresh and } \\
\text { original }\end{array}$ & 0.552 & 3.52 & 0.924 \\
\hline & The ___ 's (e-tailer) website is unadventurous* & 0.454 & 3.522 & 1.033 \\
\hline
\end{tabular}

*Reverse-coded item.

$\mathrm{SD}=$ Standard deviation

Total variance explained $=70 \%$.

Recommended procedures for scale purification normally call for refinement of the survey items, and additional data collection as needed following the EFA. Due to the 
collaborative nature of this study with the e-tailer's customer data, collecting additional data was not possible after the EFA. Accordingly, confirmatory factor analysis (CFA) was conducted using all items within each sub-dimension that were examined using EFA to determine the average variance extracted (AVE) and composite reliabilities (CR).

Next, the initial EFA for trust, E-WOM, loyalty, and purchase intentions was conducted. The scale items for trust and E-WOM loaded as distinct factors, with high reliability (Cronbach’s alpha values of .864 and .901, respectively). All factor loadings for this EFA exceeded 0.5, as recommended by Hair et al. (2006). Measures for loyalty and purchase intentions loaded together on a single factor, with loadings that ranged from .518 to .742. Upon closer examination of the scale items, it was evident that the measures of both loyalty and purchase intentions load on the same factor, indicating that they form a distinct joint construct. This makes sense. If a customer intends to do more business with a company in the near future, this customer is loyal to that firm. The Cronbach's alpha for the combined loyalty and purchase intentions constructs was .793, which is above the recommended level of .7 (Nunnally 1978). The detailed statistics for this EFA are provided in Table 12.

TABLE 12

\section{Measurement Model Evaluation: Initial EFA for Trust, E-WOM Intentions, Customer Loyalty, and Purchase Intentions}

\begin{tabular}{|c|c|c|c|c|}
\hline Construct & Item & Loading & Mean & SD \\
\hline Trust (T) & $\begin{array}{l}\text { 's (e-tailer) website seems genuinely committed to my } \\
\text { satisfaction }\end{array}$ & 0.824 & 3.930 & 0.818 \\
\hline Mean $=3.862$ & $\begin{array}{l}\text { In terms of usability, I know what to expect from ___ 's (e- } \\
\text { tailer) website }\end{array}$ & 0.775 & 4.090 & 0.733 \\
\hline $\mathrm{SD}=0.616$ & $\begin{array}{l}\text { If } \_ \text {(e-tailer) makes a claim about its product, it is } \\
\text { probably true }\end{array}$ & 0.723 & 3.860 & 0.798 \\
\hline $\begin{array}{l}\text { Customer Loyalty \& } \\
\text { Purchase Intentions (CL) }\end{array}$ & $\begin{array}{l}\text { I prefer } \_ \text {'s (e-tailer) clothing and accessories over other } \\
\text { apparel alternatives }\end{array}$ & 0.742 & 3.610 & 0.966 \\
\hline
\end{tabular}




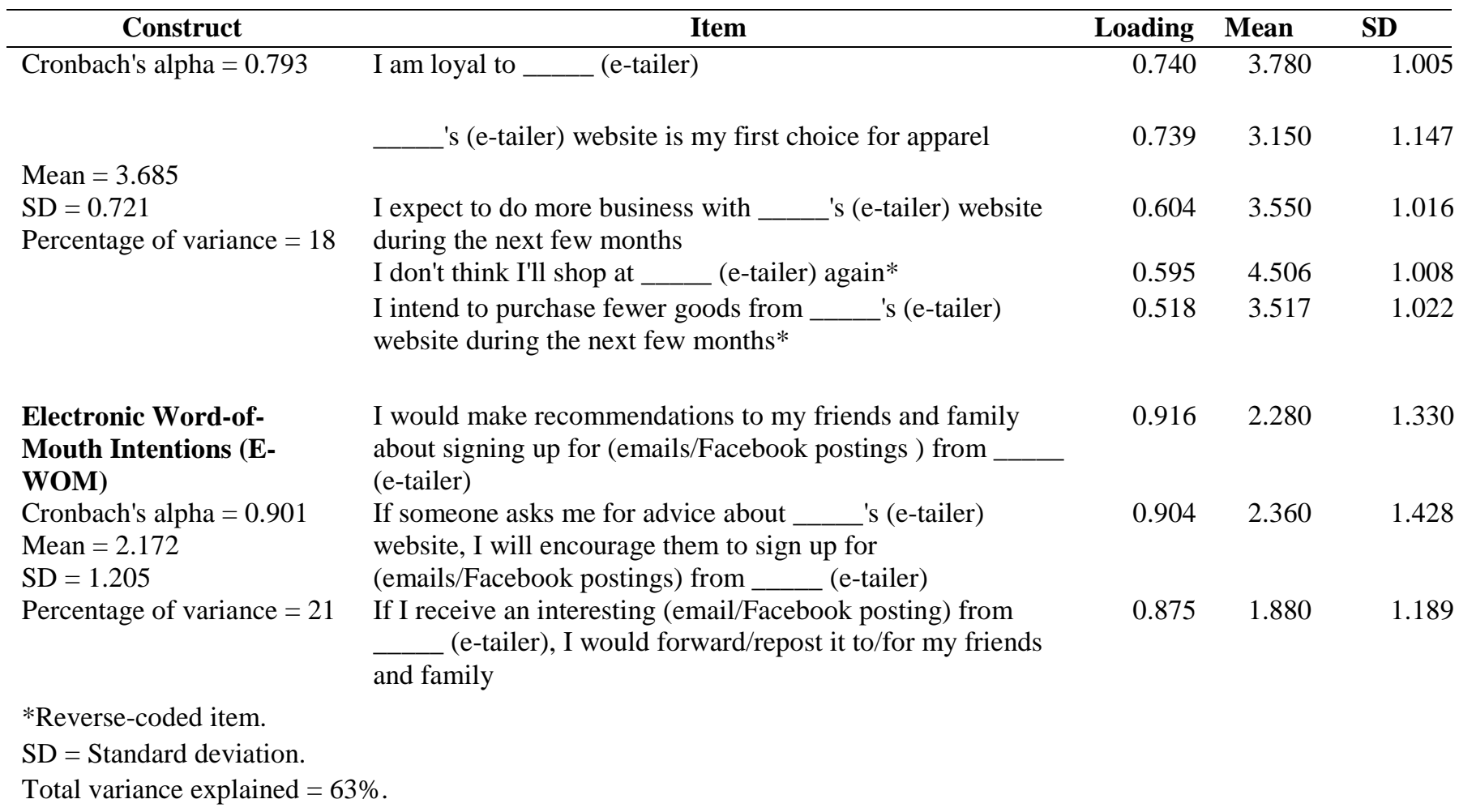

Next, the CFA was performed using LISREL 8.80. Separate CFAs were conducted for all endogenous and exogenous constructs, where CR and AVE values were examined. Reliability was assessed by checking item and construct reliability (Peter 1981). For e-servicescape, all CR values exceeded the threshold of .60 (Bagozzi and Yi 1988). All item loadings were significant $(p<.05)$. The CFA for e-servicescape indicated a good fit between the model and the data $\left(\chi^{2}=\right.$ 2,422, $d f=1,084$, RMSEA $=.048$, SRMR $=.04$, NNFI $=.98$, CFI $=.98$, and IFI $=.97)(\mathrm{Hu}$ and Bentler 1999). Three sub-dimensions of online servicescape had AVE values below the recommended minimum of .50 (Bagozzi and Yi 1988), namely interactivity (I), originality (O), and usability (U). Discriminant validity is indicated when the AVE of a construct is more than its squared correlations with other constructs (Fornell and Larcker 1981). There was a lack of discriminant validity between the following constructs: interactivity (I) and usability (U); interactivity (I) and customer reviews (CREV); interactivity (I) and customization (C); usability 
(U) and ease of payment (EP); usability (U) and relevance of information (R); usability (U) and customization (C); originality (O) and customization (C); originality $(\mathrm{O})$ and customer reviews (CREV) ; originality (O) and entertainment value (E); and originality (O) and visual appeal (V). There is significant multi-collinearity between these sub-dimensions of e-servicescape. The complete details of this first CFA iteration for online servicescape are shown in Table 13.

TABLE 13

First Iteration, Correlations and Discriminant Validity for E-Servicescape

\begin{tabular}{ccrrrrrrrrrr}
\hline & CR & \multicolumn{1}{c}{ E } & \multicolumn{1}{c}{ EP } & \multicolumn{1}{c}{ V } & \multicolumn{1}{c}{ I } & \multicolumn{1}{c}{ PS } & U & CREV & \multicolumn{1}{c}{ R } & \multicolumn{1}{c}{ C } & O \\
\hline E & 0.879 & $(0.707)$ & 0.167 & 0.236 & 0.254 & 0.217 & 0.356 & 0.007 & 0.268 & 0.235 & 0.630 \\
EP & 0.851 & 0.409 & $(0.587)$ & 0.151 & 0.227 & 0.289 & 0.462 & 0.040 & 0.301 & 0.320 & 0.174 \\
V & 0.874 & 0.486 & 0.388 & $(0.660)$ & 0.133 & 0.131 & 0.276 & 0.023 & 0.000 & 0.235 & 0.316 \\
I & 0.796 & 0.504 & 0.476 & 0.365 & $(0.496)$ & 0.198 & 0.504 & 0.573 & 0.456 & 0.573 & 0.272 \\
PS & 0.813 & 0.466 & 0.538 & 0.362 & 0.445 & $(0.542)$ & 0.347 & 0.053 & 0.297 & 0.288 & 0.196 \\
U & 0.795 & 0.597 & 0.680 & 0.525 & 0.710 & 0.589 & $(0.439)$ & 0.116 & 0.575 & 0.627 & 0.370 \\
CREV & 0.909 & 0.084 & 0.201 & 0.153 & 0.757 & 0.231 & 0.340 & $(0.834)$ & 0.624 & 0.053 & 0.010 \\
R & 0.723 & 0.518 & 0.549 & 0.459 & 0.675 & 0.545 & 0.758 & 0.790 & $(0.887)$ & 0.624 & 0.247 \\
C & 0.622 & 0.485 & 0.566 & 0.485 & 0.757 & 0.537 & 0.792 & 0.230 & 0.790 & $(0.868)$ & 0.487 \\
O & 0.606 & 0.794 & 0.417 & 0.562 & 0.522 & 0.443 & 0.608 & 0.102 & 0.497 & 0.698 & $(0.310)$ \\
\hline
\end{tabular}

aDiagonal elements in parentheses are average variance extracted (AVE) values.

bValues above the diagonal are squared phi correlation values.

'Values below the diagonal are phi correlation values.

${ }^{\mathrm{d}} \mathrm{CR}=$ Composite reliability.

Given the multi-collinearity, it was important to carefully review the measures. For originality (O), the items emphasize the design and look of the website. For example, the reversed statement "the 's (e-tailer) website features a traditional design" had the lowest lambda loading of .243. This particular scale item directly overlaps with the domain of visual appeal. Another measure for originality states "the design of the 's (e-tailer) website is fresh and original.” Newness of a website is often linked with entertainment value, as humans are variety seekers and we want to see differences in websites with each visit. Subsequently, our perception of entertainment value is greater when there is novelty. As a result, it was decided that 
originality was not a unique sub-dimension and it was removed from further consideration. The revised CFA for online servicescape is shown in Table 14.

TABLE 14

Second Iteration, Correlations and Discriminant Validity for E-Servicescape

\begin{tabular}{ccrrrrrrrrr}
\hline & CR & \multicolumn{1}{c}{ E } & \multicolumn{1}{c}{ EP } & \multicolumn{1}{c}{ V } & \multicolumn{1}{c}{ I } & \multicolumn{1}{c}{ PS } & \multicolumn{1}{c}{ U } & CREV & \multicolumn{1}{c}{ R } & \multicolumn{1}{c}{ C } \\
\hline E & 0.879 & $(0.708)$ & 0.168 & 0.237 & 0.255 & 0.218 & 0.358 & 0.007 & 0.269 & 0.493 \\
EP & 0.851 & 0.410 & $(0.587)$ & 0.151 & 0.227 & 0.291 & 0.461 & 0.040 & 0.301 & 0.267 \\
V & 0.874 & 0.487 & 0.388 & $(0.660)$ & 0.133 & 0.131 & 0.276 & 0.024 & 0.212 & 0.235 \\
I & 0.816 & 0.505 & 0.476 & 0.365 & $(0.562)$ & 0.198 & 0.504 & 0.037 & 0.454 & 0.572 \\
PS & 0.771 & 0.467 & 0.539 & 0.362 & 0.445 & $(0.543)$ & 0.347 & 0.053 & 0.297 & 0.288 \\
U & 0.795 & 0.598 & 0.679 & 0.525 & 0.710 & 0.589 & $(0.438)$ & 0.115 & 0.575 & 0.627 \\
CREV & 0.909 & 0.084 & 0.199 & 0.154 & 0.192 & 0.230 & 0.339 & $(0.834)$ & 0.024 & 0.052 \\
R & 0.887 & 0.519 & 0.549 & 0.460 & 0.674 & 0.545 & 0.758 & $* 0.155$ & $(0.723)$ & 0.623 \\
C & 0.868 & 0.702 & 0.517 & 0.485 & 0.756 & 0.537 & 0.792 & 0.229 & 0.789 & $(0.622)$ \\
\hline
\end{tabular}

${ }^{a}$ Diagonal elements in parentheses are average variance extracted (AVE) values.

${ }^{b}$ Values above the diagonal are squared phi correlation values.

'Values below the diagonal are phi correlation values.

${ }^{\mathrm{d}} \mathrm{CR}=$ Composite reliability.

The AVE for usability (U) was still below .5, and this indicated a lack of difference between usability and the following sub-dimensions: ease of payment (EP), interactivity (I), relevance of information (R), and customization (C). Following further scrutiny of the measures for usability, it was apparent that usability was too similar to other sub-dimensions of eservicescape. A measure of usability that was interconnected with both ease of payment and interactivity is "the navigational aids on this website are useful." While the statement is not directly inquiring about payment, if navigational aids are useful for both the shopping and payment process, these sub-dimensions overlap. Similarly, navigational aids allow for more customer interactivity. A reversed item for usability was "finding the exact items I want on 's (e-tailer) website is difficult.” If a customer cannot easily locate products, it is likely that this customer would believe there is little relevance in the information presented on the website. When examining usability and customization, the usability measure "there are convenient ways 
to maneuver among various pages (shirts to pants) on this website” was of particular concern. Maneuverability within the e-tailer's website coincides with customization, in the sense that increased personalization of a website makes it more straightforward for a customer to view different merchandise pages online. Based on these considerations, usability was deleted from additional analyses due to these overlaps. The details for this iteration without usability are shown in Table 15.

TABLE 15

Third Iteration, Correlations and Discriminant Validity for E-Servicescape

\begin{tabular}{ccrrrrrrrr}
\hline & CR & \multicolumn{1}{c}{ E } & \multicolumn{1}{c}{ EP } & \multicolumn{1}{c}{ V } & \multicolumn{1}{c}{ I } & \multicolumn{1}{c}{ PS } & CREV & \multicolumn{1}{c}{ R } & \multicolumn{1}{c}{ C } \\
\hline E & 0.879 & $(0.707)$ & 0.168 & 0.237 & 0.249 & 0.218 & 0.007 & 0.268 & 0.491 \\
EP & 0.851 & 0.410 & $(0.587)$ & 0.151 & 0.220 & 0.291 & 0.040 & 0.300 & 0.265 \\
V & 0.874 & 0.487 & 0.388 & $(0.660)$ & 0.130 & 0.131 & 0.023 & 0.211 & 0.234 \\
I & 0.822 & 0.499 & 0.469 & 0.360 & $(0.497)$ & 0.193 & 0.036 & 0.444 & 0.561 \\
PS & 0.771 & 0.467 & 0.539 & 0.362 & 0.439 & $(0.543)$ & 0.053 & 0.296 & 0.286 \\
CREV & 0.909 & 0.084 & 0.200 & 0.153 & 0.191 & 0.230 & $(0.834)$ & 0.024 & 0.052 \\
R & 0.887 & 0.518 & 0.548 & 0.459 & 0.666 & 0.544 & 0.155 & $(0.723)$ & 0.619 \\
C & 0.868 & 0.701 & 0.515 & 0.484 & 0.749 & 0.535 & 0.229 & 0.787 & $(0.622)$ \\
\hline
\end{tabular}

${ }^{a}$ Diagonal elements in parentheses are average variance extracted (AVE) values.

bValues above the diagonal are squared phi correlation values.

${ }^{\mathrm{c}}$ Values below the diagonal are phi correlation values.

${ }^{\mathrm{d}} \mathrm{CR}=$ Composite reliability.

The CFA results continually indicated that relevance of information (R) and customization (C) do not differ, where the AVE for customization was .622 and the squared correlation between the two was .619. A closer look at the lambda loadings revealed that one item for customization had a low lambda loading of only .323. This item was reverse-coded and stated “___ 's (e-tailer) website does not make purchase recommendations that match my needs.” It has been noted that reverse-coded items often result in unexpected factor structures and low loading values (Netemeyer, Bearden, and Sharma 2003). The original item from Harris and Goode’s (2010) scale was not reversed. The decision was made to remove this scale item for the following analyses (see Table 16 for the detailed results). 
TABLE 16

Fourth Iteration, Correlations and Discriminant Validity for E-Servicescape

\begin{tabular}{crrrrrrrrr}
\hline & CR & \multicolumn{1}{c}{ E } & \multicolumn{1}{c}{ EP } & \multicolumn{1}{c}{ V } & \multicolumn{1}{c}{ I } & \multicolumn{1}{c}{ PS } & \multicolumn{1}{c}{ CREV } & \multicolumn{1}{c}{ R } & \multicolumn{1}{c}{ C } \\
\hline E & 0.879 & $(0.708)$ & 0.168 & 0.237 & 0.249 & 0.218 & 0.043 & 0.268 & 0.518 \\
EP & 0.851 & 0.410 & $(0.587)$ & 0.151 & 0.220 & 0.291 & 0.040 & 0.300 & 0.278 \\
V & 0.874 & 0.487 & 0.388 & $(0.659)$ & 0.130 & 0.131 & 0.022 & 0.211 & 0.268 \\
I & 0.797 & 0.499 & 0.469 & 0.360 & $(0.498)$ & 0.193 & 0.037 & 0.648 & 0.548 \\
PS & 0.771 & 0.467 & 0.539 & 0.362 & 0.439 & $(0.542)$ & 0.053 & 0.296 & 0.294 \\
CREV & 0.909 & 0.208 & 0.200 & 0.149 & 0.192 & 0.230 & $(0.833)$ & 0.024 & 0.051 \\
R & 0.887 & 0.518 & 0.548 & 0.459 & 0.805 & 0.544 & 0.155 & $(0.723)$ & 0.619 \\
C & 0.833 & 0.720 & 0.527 & 0.518 & 0.740 & 0.542 & 0.225 & 0.787 & $(0.625)$ \\
\hline
\end{tabular}

${ }^{a}$ Diagonal elements in parentheses are average variance extracted (AVE) values.

${ }^{b}$ Values above the diagonal are squared phi correlation values.

${ }^{\mathrm{c}}$ Values below the diagonal are phi correlation values.

${ }^{\mathrm{d}} \mathrm{CR}=$ Composite reliability.

The removal of the reversed customization survey item did not impact the lack of discriminant validity between relevance of information (R) and customization (C). Further inspection of the two sub-dimensions exposed similarities. If a customer deems the information presented on the website to be germane to their needs, it is probable that the customer will also consider the website to be personalized for them. The commonality between relevance of information and customization became more apparent when the measures were compared. For example, "all relevant information is easily available on this website" is like "this website is laid out to satisfy my needs.” For the former statement, a customer would respond to it with the mentality that the information is relevant to them personally. Hence, the customer would also believe the website layout is satisfactory to their needs. Moreover, recall that the EFA for online servicescape also resulted in these two sub-dimensions as a single factor. The decision was made to combine relevance of information and customization, which was termed "relevance and customization” (RC) in future analyses. This CFA iteration is presented in Table 17. 
TABLE 17

Fifth Iteration, Correlations and Discriminant Validity for E-Servicescape

\begin{tabular}{ccrrrrrrr}
\hline & CR & \multicolumn{1}{c}{ E } & \multicolumn{1}{c}{ EP } & \multicolumn{1}{c}{ V } & \multicolumn{1}{c}{ I } & \multicolumn{1}{c}{ PS } & CREV & \multicolumn{1}{c}{ RC } \\
\hline E & 0.879 & $(0.707)$ & 0.167 & 0.236 & 0.249 & 0.217 & 0.008 & 0.410 \\
EP & 0.851 & 0.409 & $(0.587)$ & 0.151 & 0.222 & 0.288 & 0.040 & 0.338 \\
V & 0.874 & 0.486 & 0.388 & $(0.660)$ & 0.130 & 0.131 & 0.022 & 0.269 \\
I & 0.797 & 0.499 & 0.471 & 0.361 & $(0.498)$ & 0.193 & 0.037 & 0.549 \\
PS & 0.772 & 0.466 & 0.537 & 0.362 & 0.439 & $(0.543)$ & 0.053 & 0.339 \\
CREV & 0.909 & 0.087 & 0.200 & 0.148 & 0.192 & 0.231 & $(0.834)$ & 0.039 \\
RC & 0.899 & 0.640 & 0.581 & 0.519 & 0.741 & 0.582 & 0.198 & $(0.599)$ \\
\hline
\end{tabular}

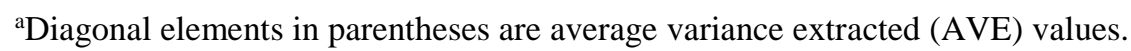

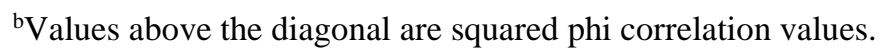

${ }^{\mathrm{c}}$ Values below the diagonal are phi correlation values.

${ }^{\mathrm{d}} \mathrm{CR}=$ Composite reliability.

Interactivity (I) had an AVE value slightly below the recommended value of .5. Two of the items were reverse-coded, namely "this website does not let me view merchandise in different ways" and "the ___ (e-tailer) website does not engage me.” These two survey statements had low lambda loadings, .424 and .318, respectively. Given that reverse-coded survey questions can be problematic, it was deemed appropriate to remove these two items from subsequent analyses. The revised CFA details for online servicescape are provided in Table 18.

TABLE 18 Sixth Iteration, Correlations and Discriminant Validity for E-Servicescape

\begin{tabular}{ccrrrrrrr}
\hline & CR & \multicolumn{1}{c}{ E } & \multicolumn{1}{c}{ EP } & \multicolumn{1}{c}{ V } & \multicolumn{1}{c}{ I } & \multicolumn{1}{c}{ PS } & CREV & \multicolumn{1}{c}{ RC } \\
\hline E & 0.879 & $(0.707)$ & 0.167 & 0.236 & 0.193 & 0.217 & 0.008 & 0.410 \\
EP & 0.851 & 0.409 & $(0.588)$ & 0.151 & 0.172 & 0.288 & 0.044 & 0.338 \\
V & 0.874 & 0.486 & 0.388 & $(0.660)$ & 0.104 & 0.131 & 0.022 & 0.269 \\
I & 0.779 & 0.439 & 0.415 & 0.323 & $(0.559)$ & 0.193 & 0.039 & 0.549 \\
PS & 0.772 & 0.466 & 0.537 & 0.362 & 0.439 & $(0.543)$ & 0.053 & 0.339 \\
CREV & 0.909 & 0.087 & 0.210 & 0.148 & 0.197 & 0.231 & $(0.834)$ & 0.039 \\
RC & 0.899 & 0.640 & 0.581 & 0.519 & 0.741 & 0.582 & 0.198 & $(0.599)$ \\
\hline
\end{tabular}

a Diagonal elements in parentheses are average variance extracted (AVE) values.

${ }^{\text {b}}$ Values above the diagonal are squared phi correlation values.

${ }^{c}$ Values below the diagonal are phi correlation values.

${ }^{\mathrm{d}} \mathrm{CR}=$ Composite reliability.

Finally, an additional item for visual appeal was examined for possible removal. The item 
had a loading of .32. The item was reverse-coded from the original e-servicescape scale (Harris and Goode 2010) and stated "the 's (e-tailer) website does not use visually appealing graphics.” The following fit statistics indicated a good fit for the final measurement model: $\chi^{2}=$ 1,629, $d f=549, \mathrm{RMSEA}=.05, \mathrm{SRMR}=.04, \mathrm{NNFI}=.98, \mathrm{CFI}=.98$, and $\mathrm{IFI}=.98(\mathrm{Hu}$ and Bentler 1999). The $\chi^{2}$ to degrees of freedom ratio was 2.97 , which is less than 3 as recommended (Hu and Bentler 1999). All completely standardized loadings were statistically significant ( $p<$ $.05)$ with $t$-values that ranged from 10.58 to 34.49 . All loadings exceeded the .5 minimum loading (Gerbing and Anderson 1988). Composite reliabilities ranged from .771 to .943 and AVE values ranged from .534 to .846, all above recommended levels (Fornell and Larcker 1981). As an additional check, face validity of the measurement items was assessed a final time; it was determined that the items were appropriate measures. The final CFA results for online servicescape are shown in Table 19.

TABLE 19

Seventh Iteration, Correlations and Discriminant Validity for E-Servicescape

\begin{tabular}{ccrrrrrrr}
\hline & CR & \multicolumn{1}{c}{ E } & \multicolumn{1}{c}{ EP } & \multicolumn{1}{c}{ V } & \multicolumn{1}{c}{ I } & \multicolumn{1}{c}{ PS } & \multicolumn{1}{c}{ CREV } & \multicolumn{1}{c}{ RC } \\
\hline E & 0.879 & $(0.707)$ & 0.167 & 0.233 & 0.249 & 0.217 & 0.008 & 0.408 \\
EP & 0.851 & 0.409 & $(0.587)$ & 0.147 & 0.222 & 0.288 & 0.044 & 0.338 \\
V & 0.943 & 0.483 & 0.384 & $(0.846)$ & 0.129 & 0.131 & 0.022 & 0.267 \\
I & 0.773 & 0.499 & 0.471 & 0.359 & $(0.534)$ & 0.193 & 0.037 & 0.549 \\
PS & 0.771 & 0.466 & 0.537 & 0.362 & 0.439 & $(0.543)$ & 0.053 & 0.339 \\
CREV & 0.909 & 0.087 & 0.209 & 0.147 & 0.192 & 0.231 & $(0.833)$ & 0.039 \\
RC & 0.899 & 0.639 & 0.581 & 0.517 & 0.741 & 0.582 & 0.198 & $(0.599)$ \\
\hline
\end{tabular}

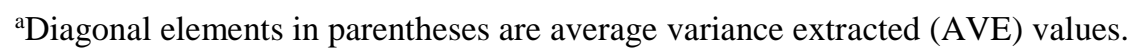

${ }^{b}$ Values above the diagonal are squared phi correlation values.

'Values below the diagonal are phi correlation values.

${ }^{\mathrm{d}} \mathrm{CR}=$ Composite reliability.

For the other CFA with trust (T), E-WOM, loyalty (L), and purchase intentions (PI), all CR values ranged from .660 to .905 . The CFA indicated a good fit between the model and the study data: $\chi^{2}=1,908, d f=657$, RMSEA $=.056$, SRMR $=.042, \mathrm{NNFI}=.98, \mathrm{CFI}=.98$, and IFI $=.98$ (Hu and Bentler 1999). For trust and E-WOM, AVE values exceeded .5, the recommended 
value (Fornell and Larcker 1981). With the exception of one purchase intentions item and one loyalty item, completely standardized lambda loadings were greater than .5 (Gerbing and Anderson 1988). There is a problem with discriminant validity for purchase intentions and loyalty, along with purchase intentions and trust. The details of the initial CFA for trust, EWOM, loyalty, and purchase intentions are presented in Table 20.

TABLE 20

First Iteration, Correlations and Discriminant Validity for Mediator and Endogenous Variables (Trust, E-WOM Intentions, Customer Loyalty, and Purchase Intentions)

\begin{tabular}{crrrrr}
\hline & CR & \multicolumn{1}{c}{ T } & E-WOM & \multicolumn{1}{c}{ CL } & \multicolumn{1}{c}{ PI } \\
\hline T & 0.868 & $(0.575)$ & 0.100 & 0.388 & 0.518 \\
E-WOM & 0.905 & 0.317 & $(0.761)$ & 0.099 & 0.112 \\
CL & 0.699 & 0.623 & 0.314 & $(0.462)$ & 0.882 \\
PI & 0.660 & 0.720 & 0.334 & 0.939 & $(0.404)$ \\
\hline
\end{tabular}

${ }^{a}$ Diagonal elements in parentheses are average variance extracted (AVE) values.

${ }^{b}$ Values above the diagonal are squared phi correlation values.

'Values below the diagonal are phi correlation values.

${ }^{\mathrm{d}} \mathrm{CR}=$ Composite reliability.

Recall that the initial EFA resulted in both loyalty (L) and purchase intentions (PI)

loading as a single factor. It was deemed appropriate to combine these two constructs, which will be known as loyalty for further analyses. In Table 21, the results of this CFA iteration are shown.

TABLE 21

Second Iteration, Correlations and Discriminant Validity for Mediator and Endogenous Variables (Trust, E-WOM Intentions, and Customer Loyalty)

\begin{tabular}{clrrr}
\hline & CR & \multicolumn{1}{c}{ T } & E-WOM & \multicolumn{1}{c}{ CL } \\
\hline T & 0.868 & $(0.573)$ & 0.100 & 0.460 \\
E-WOM & 0.905 & 0.317 & $(0.762)$ & 0.108 \\
CL & 0.799 & 0.678 & 0.329 & $(0.416)$ \\
\hline
\end{tabular}

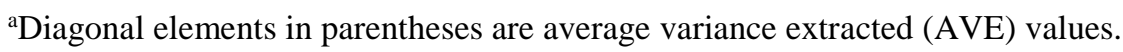

${ }^{b}$ Values above the diagonal are squared phi correlation values.

${ }^{\mathrm{C}}$ Values below the diagonal are phi correlation values.

${ }^{\mathrm{d}} \mathrm{CR}=$ Composite reliability. 
Note that the combined construct loyalty had a low AVE of only .416, which is less than the recommended minimum of .5 (Fornell and Larcker 1981). A closer look at the survey items showed the lowest lambda loadings for the two reverse-coded statements of this construct. The two items were “I don’t think I'll shop again at (e-tailer)" and "I intend to purchase fewer goods from 's (e-tailer) website during the next few months.” The loadings were .348 and .418, respectively, which are below the minimum acceptable level of .5 (Gerbing and Anderson 1988). The decision was made to remove these items due to the low loadings, which is likely due to the reversed wording of the survey statements. With the deletion of these reverse-coded items from the CFA, loyalty is a discriminant construct from both trust and E-WOM intentions, with an AVE value of .545. The detailed results are provided in Table 22.

TABLE 22

\section{Third Iteration, Correlations and Discriminant Validity for Mediator and Endogenous Variables (Trust, E-WOM Intentions, and Customer Loyalty)}

\begin{tabular}{ccrrr}
\hline & CR & \multicolumn{1}{c}{ T } & E-WOM & \multicolumn{1}{c}{ CL } \\
\hline T & 0.868 & $(0.575)$ & 0.100 & 0.442 \\
E-WOM & 0.905 & 0.317 & $(0.761)$ & 0.100 \\
CL & 0.825 & 0.665 & 0.317 & $(0.545)$ \\
\hline
\end{tabular}

aDiagonal elements in parentheses are average variance extracted (AVE) values.

${ }^{b}$ Values above the diagonal are squared phi correlation values.

${ }^{\mathrm{c}}$ Values below the diagonal are phi correlation values.

${ }^{\mathrm{d}} \mathrm{CR}=$ Composite reliability.

Before finalizing the CFA, all lambda loadings were carefully examined. There were five items for trust, with one reverse-coded item. The statement "few limits exist on how far (e-tailer) will go to solve my website service problems” had the lowest lambda loading of .521, while the other loadings ranged from .758 to .811 for this construct. It was decided that the removal of this item was necessary. Although the item did not have reversed wording, it was potentially confusing for respondents. CR values ranged from .825 to .905 , which exceeded the minimum acceptable value (Fornell and Larcker 1981). AVE values are all above the 
recommended .5 (Fornell and Larcker 1981). The CFA indicated a good fit between the model and the study data: $\chi^{2}=1,629, d f=549$, RMSEA $=.057$, SRMR $=.049$, NNFI $=.98$, CFI $=.98$, and IFI $=.98$ (Hu and Bentler 1999). The final CFA for trust, E-WOM intentions, and customer loyalty is presented in Table 23.

TABLE 23

Fourth Iteration, Correlations and Discriminant Validity for Mediator and Endogenous Variables (Trust, E-WOM Intentions, and Customer Loyalty)

\begin{tabular}{ccrrr} 
& CR & \multicolumn{1}{c}{ T } & E-WOM & \multicolumn{1}{c}{ CL } \\
\hline T & 0.881 & $(0.651)$ & 0.095 & 0.445 \\
E-WOM & 0.905 & 0.309 & $(0.761)$ & 0.105 \\
CL & 0.825 & 0.667 & 0.324 & $(0.547)$ \\
\hline
\end{tabular}

${ }^{a}$ Diagonal elements in parentheses are average variance extracted (AVE) values.

${ }^{b}$ Values above the diagonal are squared phi correlation values.

${ }^{\mathrm{c}}$ Values below the diagonal are phi correlation values.

${ }^{\mathrm{d}} \mathrm{CR}=$ Composite reliability.

After the CFA iterations and removal of reverse-coded and poorly-worded items, online servicescape had 24 measurements items. Trust, loyalty, and E-WOM had 11 items total. The final items for hypotheses testing for all variables are presented in Table 24.

TABLE 24

Final Measurement Items for All Variables

\begin{tabular}{llr}
\hline \multicolumn{1}{c}{ Construct } & \multicolumn{1}{c}{ Item } & $\begin{array}{c}\text { Lambda } \\
\text { Loading }\end{array}$ \\
\hline $\begin{array}{l}\text { Relevance \& } \\
\text { Customization (RC) }\end{array}$ & $\begin{array}{l}\text { Technical details about the items can be easily accessed easily when } \\
\text { browsing this website }\end{array}$ & 0.802 \\
Mean = 3.665 & All relevant information is easily available on this website & 0.792 \\
SD =0.699 & Each page on the website clearly indicates what one can expect to find & 0.803 \\
& The services of this website are often personalized to my needs & 0.723 \\
& This website is laid out to satisfy my needs & 0.793 \\
& This website treats me like an individual & 0.725 \\
Entertainment Value (E) & I find this website entertaining & 0.878 \\
Mean = 3.341 & The enthusiasm displayed on this website lifts my spirits & 0.847 \\
SD = 0.831 & It is fun shopping on _s (e-tailer) website even when I do not & 0.796 \\
& make a purchase & \\
Ease of Payment (EP) & On 's (e-tailer) website, paying for items involves entering too & 0.770 \\
Mean = 3.916 & many details*
\end{tabular}




\begin{tabular}{|c|c|c|}
\hline Construct & Item & $\begin{array}{l}\text { Lambda } \\
\text { Loading }\end{array}$ \\
\hline \multirow[t]{3}{*}{$\mathrm{SD}=0.720$} & Payment procedures take a long time to complete on this website* & 0.758 \\
\hline & 's (e-tailer) online payment process is reasonable & 0.746 \\
\hline & Paying for goods is straightforward on this website & 0.791 \\
\hline Visual Appeal (V) & The way ___ 's (e-tailer) website displays products is attractive & 0.931 \\
\hline Mean $=4.136$ & I like the look of ___ 's (e-tailer) website & 0.904 \\
\hline $\mathrm{SD}=0.857$ & This website is aesthetically appealing & 0.923 \\
\hline Interactivity (I) & This website helps me compare products & 0.817 \\
\hline Mean $=3.3333$ & The ___ (e-tailer) website helps me compare prices & 0.597 \\
\hline $\mathrm{SD}=0.728$ & $\begin{array}{l}\text { This website has a search tool which helps me find exactly what I } \\
\text { want }\end{array}$ & 0.807 \\
\hline $\begin{array}{l}\text { Customer Reviews } \\
\text { (CREV) }\end{array}$ & $\begin{array}{l}\text { Customer reviews are helpful when I make purchase decisions on } \\
\text { 's (e-tailer) website }\end{array}$ & 0.927 \\
\hline $\begin{array}{l}\text { Mean }=3.873 \\
\mathrm{SD}=1.114\end{array}$ & I like to read customer reviews on ___ 's (e-tailer) website & 0.898 \\
\hline \multirow{3}{*}{$\begin{array}{l}\text { Perceived Security (PS) } \\
\text { Mean }=3.810 \\
\text { SD }=0.692\end{array}$} & Overall, ___ 's (e-tailer) website appears to be security conscious & 0.899 \\
\hline & $\begin{array}{l}\text { I have no security concerns when I purchase apparel and accessories } \\
\text { from this website }\end{array}$ & 0.762 \\
\hline & The security systems of this website appear rigorous & 0.589 \\
\hline $\begin{array}{l}\text { Trust (T) } \\
\text { Mean }=4.000\end{array}$ & $\begin{array}{l}\text { 's (e-tailer) website seems genuinely committed to my } \\
\text { satisfaction }\end{array}$ & 0.811 \\
\hline \multirow[t]{3}{*}{$\mathrm{SD}=0.663$} & Overall, I trust this website & 0.870 \\
\hline & $\begin{array}{l}\text { In terms of usability, I know what to expect from ___ 's (e-tailer) } \\
\text { website }\end{array}$ & 0.784 \\
\hline & If ___ (e-tailer) makes a claim about its product, it is probably true & 0.758 \\
\hline $\begin{array}{l}\text { Customer Loyalty \& } \\
\text { Purchase Intentions (CL) }\end{array}$ & $\begin{array}{l}\text { I prefer } \\
\text { alternatives }\end{array}$ & 0.780 \\
\hline Mean $=3.522$ & I am loyal to ___ (e-tailer) & 0.770 \\
\hline \multirow[t]{2}{*}{$\mathrm{SD}=0.831$} & _s (e-tailer) website is my first choice for apparel & 0.813 \\
\hline & $\begin{array}{l}\text { I expect to do more business with ___ 's (e-tailer) website during } \\
\text { the next few months }\end{array}$ & 0.563 \\
\hline \multirow{3}{*}{$\begin{array}{l}\text { Electronic Word-of- } \\
\text { Mouth Intentions (E- } \\
\text { WOM) } \\
\text { Mean = } 2.172 \\
\text { SD = } 1.205\end{array}$} & $\begin{array}{l}\text { I would make recommendations to my friends and family about } \\
\text { signing up for (emails/Facebook updates ) from __ (e-tailer) }\end{array}$ & 0.943 \\
\hline & $\begin{array}{l}\text { If someone asks me for advice about } \_ \text {'s (e-tailer) website, I will } \\
\text { encourage them to sign up for (emails/Facebook updates) from } \\
\text { (e-tailer) }\end{array}$ & 0.892 \\
\hline & $\begin{array}{l}\text { If I receive an interesting (email/Facebook posting) from } \\
\text { tailer), I would forward/repost it to/for my friends and family }\end{array}$ & 0.774 \\
\hline
\end{tabular}




\section{Testing for Common Method Bias}

Since data were derived from customers’ self-reported perceptions, there is potential for common method bias in this study. Before hypotheses testing, a common method factor model was tested (Podsakoff et al. 2003). The common method factor model included the 10 subdimensions of online servicescape and an additional same-source construct as an eleventh subdimension of online servicescape. The common method factor results were compared to the model without the additional, same-source factor. Based on the chi-square significance test, findings indicated no difference between the two models. It was determined that relationships tested in this research study were not affected by common method bias.

\section{Hypotheses Testing}

Hypotheses were tested in two stages. First, structural equation modeling with maximum likelihood estimation was used to test the hypothesized model using the entire data sample $(\mathrm{n}=$ 613). Relationships were first converted into a set of structural equations corresponding to the model presented in Figure 4. Recall that originality and usability were both removed due to overlap with other sub-dimensions, H1c and H1h respectively. Customization (H1e) was combined with relevance of information (H1g). Also, loyalty and purchase intentions represented a single construct, now H4. The structural model provided a good overall fit to the study data: $\chi^{2}$ $=1,724, d f=550, \mathrm{RMSEA}=.049, \mathrm{SRMR}=.052, \mathrm{NNFI}=.98, \mathrm{CFI}=.96$, and $\mathrm{IFI}=.97(\mathrm{Hu}$ and Bentler 1999). Detailed statistics from the hypotheses testing and model fit indices are provided in Table 25. 
FIGURE 4

\section{Revised Research Model}

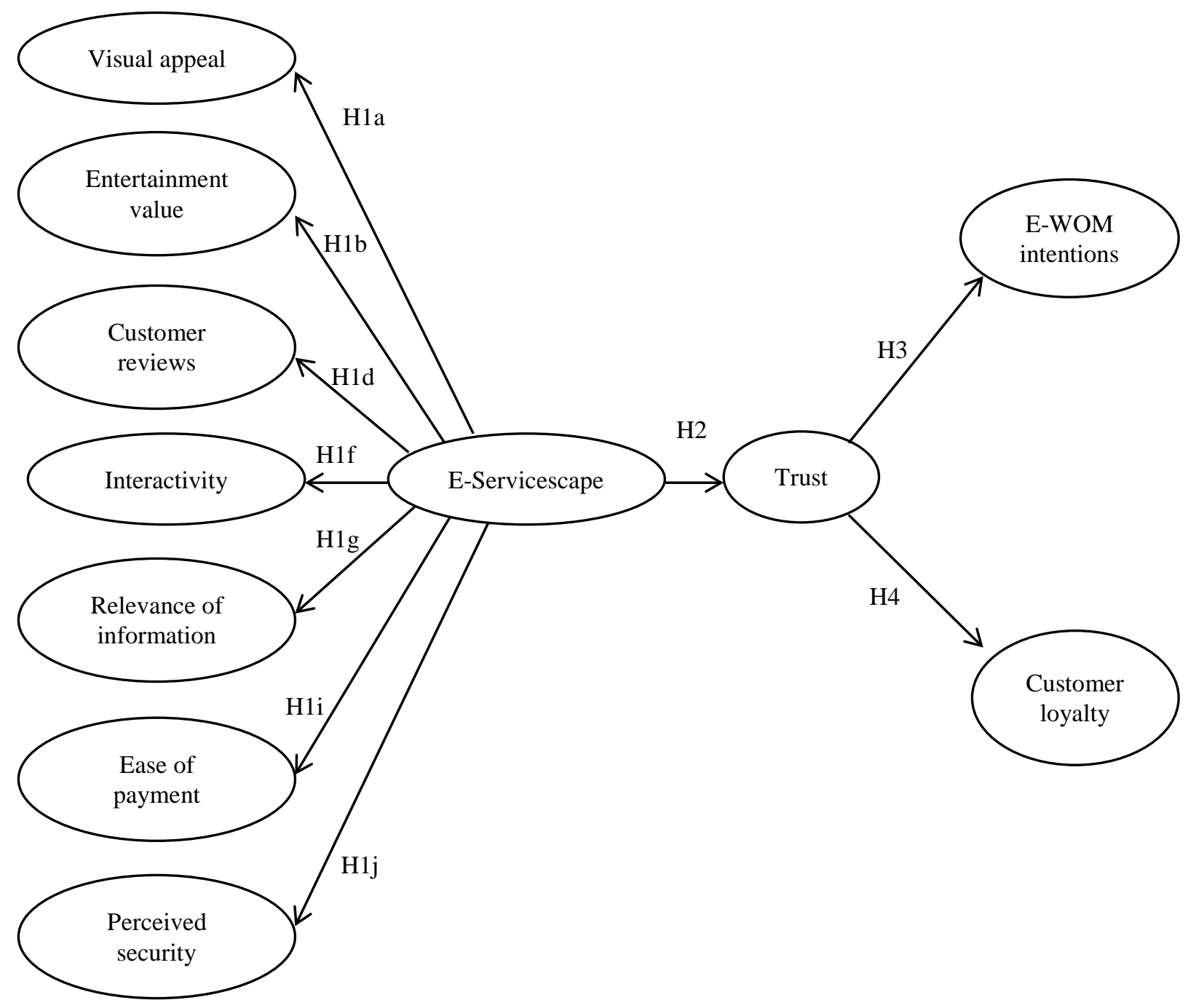

H1a to H1j were evaluated by examining the path coefficients between each subdimension of e-servicescape (i.e., visual appeal, entertainment value, ease of payment, etc.) and e-servicescape, where e-servicescape serves as a second-order construct. H2 was evaluated for eservicescape toward trust, respectively. H3 and H4 were evaluated by examining the path estimates for trust toward E-WOM and loyalty, respectively. 
Both H1a and H1b predicted e-servicescape would be positively associated with visual appeal and entertainment value, which are both sub-dimensions of aesthetic appeal. These hypotheses were supported (completely standardized path estimate $=.549$, t-value $=13.34$, $\mathrm{p}$ value $<.05$; completely standardized path estimate $=.683$, t-value $=16.15$, p-value $<.05$, respectively). For the layout and functionality dimension, H1d, H1f, and H1g predicted online servicescape would be positively correlated with customer reviews, interactivity, and relevance of information. These three hypotheses were also supported (completely standardized path estimate $=.235$, t-value $=4.86$, p-value $<.05$; completely standardized path estimate $=.474$, tvalue $=13.99, \mathrm{p}$-value $<.05$; completely standardized path estimate $=.619$, t-value $=20.58, \mathrm{p}$ value $<.05$, respectively). $\mathrm{H} 1 \mathrm{i}$ and $\mathrm{H} 1 \mathrm{j}$ predicted e-servicescape would be positively related to ease of payment and perceived security; both of these are part of the financial security dimension of online servicescape. Both of these hypotheses were supported (completely standardized path estimate $=.423, \mathrm{t}$-value $=14.90, \mathrm{p}$-value $<.05 ;$ completely standardized path estimate $=.482$, tvalue $=17.11, \mathrm{p}$-value $<.05$, respectively).

$\mathrm{H} 2$ posited that e-servicescape would be positively related to trust. This hypothesis was supported (completely standardized path estimate $=.923$, t-value $=22.74$, $\mathrm{p}$-value $<.05$ ). The $\mathrm{R}^{2}$ value of .852 for trust was high, which indicates that these online servicescape sub-dimensions are robust predictors of trust in online retailers. H3 predicted that trust would be positively associated with E-WOM behavioral intentions. H3 was supported (completely standardized path estimate $=.340$, t-value $=8.00$, $\mathrm{p}$-value $<.05$ ). The $\mathrm{R}^{2}$ value of .116 for E-WOM intentions was not as robust. This low $\mathrm{R}^{2}$ value indicates that other important variables may help better explain E-WOM behaviors. Finally, H4 posited that trust would be positively correlated with customer loyalty, which was supported (completely standardized path estimate $=.695$, t-value $=15.63$, p- 
value $<.05)$. The $\mathrm{R}^{2}$ value .483 for loyalty was also high, which suggests that trust accounts for a large portion of customer loyalty. Trust is a significant and robust predictor of consumers’ patronage behaviors. The research model with the completely standardized path estimates is presented in Figure 5.

FIGURE 5

\section{Research Model with Path Estimates for Full Sample}

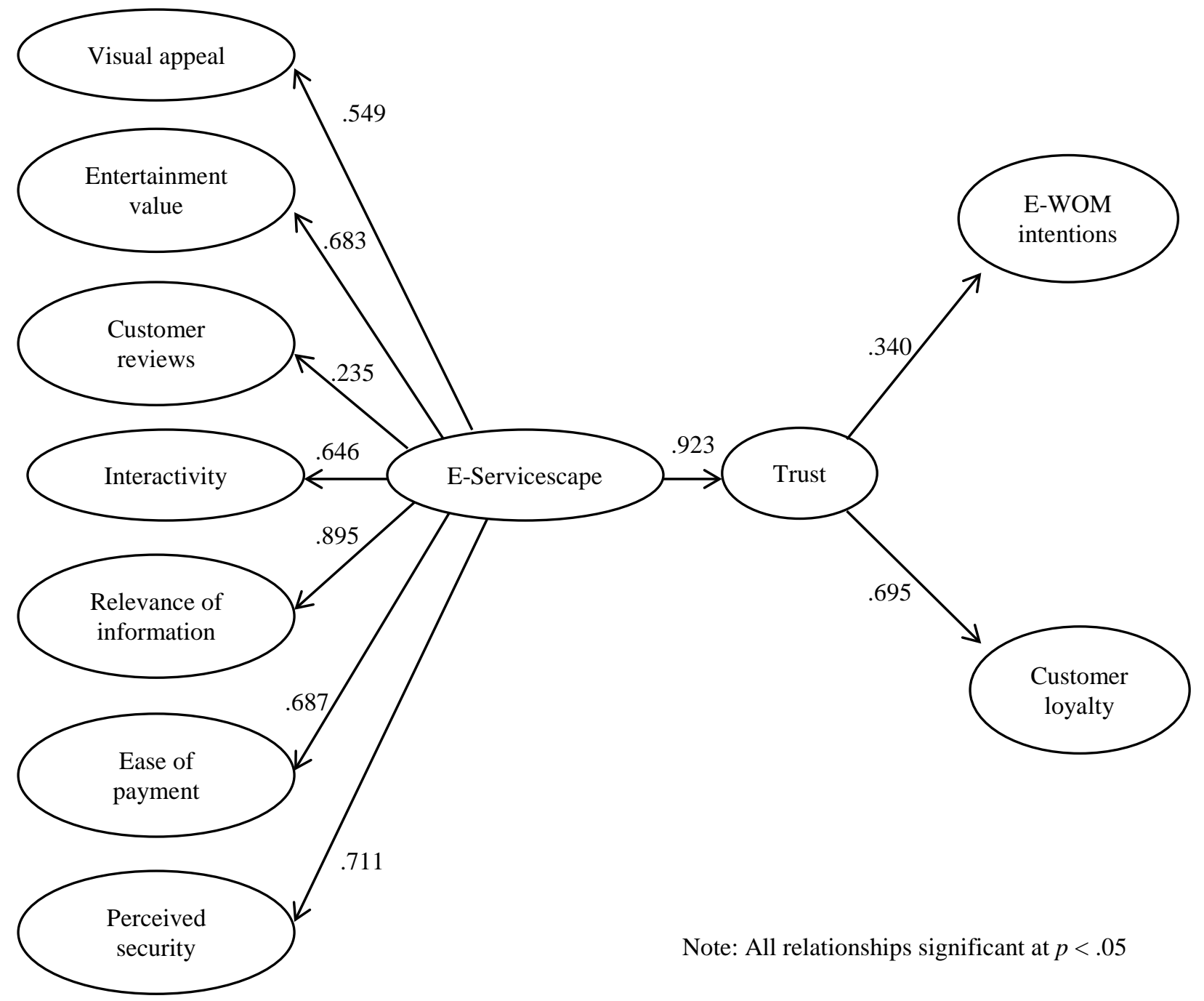


TABLE 25

\section{Summary of Hypotheses Testing}

\begin{tabular}{llrrrc}
\hline & \multicolumn{1}{c}{ Hypothesis } & Path estimate & $\boldsymbol{p}$-value & $\boldsymbol{t}$-value & Result \\
\hline H1a & E-servicescape $\rightarrow$ Visual appeal & 0.549 & $<.05$ & 13.34 & Supported \\
H1b & E-servicescape $\rightarrow$ Entertainment value & 0.683 & $<.05$ & 16.15 & Supported \\
H1d & E-servicescape $\rightarrow$ Customer reviews & 0.235 & $<.05$ & 4.86 & Supported \\
H1f & E-servicescape $\rightarrow$ Interactivity & 0.646 & $<.05$ & 13.99 & Supported \\
H1g & E-servicescape $\rightarrow$ Relevance of information & 0.895 & $<.05$ & 20.58 & Supported \\
H1i & E-servicescape $\rightarrow$ Ease of payment & 0.687 & $<.05$ & 14.90 & Supported \\
H1j & E-servicescape $\rightarrow$ Perceived security & 0.711 & $<.05$ & 17.11 & Supported \\
H2 & E-servicescape $\rightarrow$ Trust & 0.923 & $<.05$ & 22.74 & Supported \\
H3 & Trust $\rightarrow$ E-WOM intentions & 0.340 & $<.05$ & 8.00 & Supported \\
H4 & Trust $\rightarrow$ Customer loyalty & 0.695 & $<.05$ & 15.63 & Supported \\
& & & & & \\
Global Model Fit Diagnostics: & & & & \\
Chi square $(d f)$ & $1723.963(550)$ & & & \\
p-value & 0.000 & & & \\
RMSEA & 0.049 & & & \\
SRMR & 0.052 & & & \\
GFI & 0.86 & & & \\
NNFI & 0.98 & & & \\
CFI & 0.96 & & & \\
IFI & 0.98 & & & & \\
\hline
\end{tabular}

Hypotheses Testing: Multi-Group Analysis

The final set of hypotheses predicted the effect of the electronic communication method on the relationships in the revised research model (see Figure 4). First, the total sample was divided into two sub-samples based on method of communication with the e-tailer (288 email receivers and 325 Facebook posting receivers) to analyze the effect. The research model (see Figure 4) was re-estimated individually for each sub-sample. The structural model provided a good overall fit to the data for the email group: $\chi^{2}=1,087, d f=550$, RMSEA $=.058$, SRMR $=$ $.066, \mathrm{NNFI}=.98, \mathrm{CFI}=.98$, and IFI $=.98(\mathrm{Hu}$ and Bentler 1999). The following fit statistics indicated a good fit for the Facebook postings sub-sample data and structural model: $\chi^{2}=1,232$, $d f=550, \mathrm{RMSEA}=.062, \mathrm{SRMR}=.056, \mathrm{NNFI}=.97, \mathrm{CFI}=.97$, and IFI $=.97(\mathrm{Hu}$ and Bentler 1999). 
Since different groups were being compared using the same model in this research study, the chi-square test was not appropriate. The degrees of freedom were identical, which would result in a denominator of zero when comparing the chi-square statistics. It was determined that the Bayesian Information Criterion (BIC) was the best method for evaluating the two groups. When compared to other statistics for assessing model fit, the BIC resolves the issue of overfitting models by including the number of parameters in the calculation. This penalty term for fitting the model is larger for the BIC, as compared to other criterion, which results in the BIC being more stringent (Kass and Raftery 1995). The BIC was calculated for each sub-sample with the following formula, where $\mathrm{k}$ is the number of parameters and $\mathrm{n}$ is the sample size for that particular group:

$$
\mathrm{BIC}=\chi^{2}+k \cdot \ln (n)
$$

The difference in the BIC values was examined. The difference was 162, which indicated a very strong difference between the two groups (Kass and Raftery 1995). The email group had the lower BIC, which suggested a better fit between the structural model and data for the email group as compared to the Facebook group (see Table 26 for details).

TABLE 26

Comparing Two Groups Using BIC

\begin{tabular}{lrrrrr}
\hline & $\begin{array}{c}\text { Chi- } \\
\text { square }\end{array}$ & \multicolumn{1}{c}{ n } & k & BIC & Difference \\
\hline Email & 1025 & 288 & 124 & 1727 & \multirow{2}{*}{162} \\
Facebook & 1172 & 325 & 124 & 1889 & \\
\hline $\mathrm{n}=$ Sub-sample size & & & & & \\
$\mathrm{k}=$ Parameters & & & & & \\
BIC = Bayesian Information Criterion & & & &
\end{tabular}

Findings suggested the electronic communication method affected the relationships. Completely standardized path estimates for each group were compared for all relationships. For the aesthetic appeal dimension of online servicescape, emails exercised stronger effects on 
customers' perceptions of visual appeal and entertainment value (path estimates of .628 and .692, respectively) as compared to Facebook postings (.474 and .669 path estimates, respectively). Thus, H6a and H6b were supported.

Regarding the layout and functionality dimension of e-servicescape, communication method impacted the customer reviews and relevance of information sub-dimensions. Emails affected the relationships between customer reviews and relevance of information and eservicescape (.254 and .895, respectively) more than social network postings (.212 and .862, respectively). H6d and H6g were also supported. H6f predicted that emails would have more influence on the relationship between interactivity and e-servicescape for the email group (.630) versus the Facebook group (.663); this hypothesis was not supported.

For the financial security dimension of online servicescape, emails had a stronger impact on perceived security (.752) as compared to social network postings (.677), providing support for H6j. Surprisingly, the results for the ease of payment sub-dimension did not support H6i, where communication method did not affect this relationship. The path estimates were close, with emails at .685 and Facebook postings at .689.

H7 predicted electronic communication method would influence the relationship between e-servicscape and trust, with the email sub-sample showing higher levels of trust. $\mathrm{H7}$ was not supported. For the email group, the path estimate was .908 and .936 for the Facebook posting group. For the relationship between trust and E-WOM, the communication method was a significant factor. The path estimate was .501 for the email group and .315 for the Facebook group, providing support for H8. Finally, for H9, emails had a stronger effect on the trust and loyalty relationship, as compared to the social network postings (.728 and .671, respectively). 
The details comparing the completely standardized path estimates and $t$-values for each subsample are presented in Table 27.

TABLE 27

Summary of Hypotheses Testing, Multi-Group Analysis

\begin{tabular}{|c|c|c|c|c|c|c|}
\hline & & \multicolumn{2}{|c|}{ Email Group } & \multicolumn{2}{|c|}{ Facebook Group } & \\
\hline & Path & $\begin{array}{c}\text { Path } \\
\text { estimate }\end{array}$ & $t$-value & $\begin{array}{c}\text { Path } \\
\text { estimate }\end{array}$ & $t$-value & Result \\
\hline H6a & E-servicescape $\rightarrow$ Visual appeal & 0.628 & 10.87 & 0.474 & 8.16 & Supported \\
\hline H6b & E-servicescape $\rightarrow$ Entertainment value & 0.692 & 11.55 & 0.669 & 11.18 & Supported \\
\hline H6d & E-servicescape $\rightarrow$ Customer reviews & 0.254 & 4.01 & 0.212 & 2.82 & Supported \\
\hline H6f & E-servicescape $\rightarrow$ Interactivity & 0.630 & 9.87 & 0.663 & 9.94 & Not supported \\
\hline H6g & E-servicescape $\rightarrow$ Relevance of information & 0.895 & 14.85 & 0.862 & 14.31 & Supported \\
\hline H6i & E-servicescape $\rightarrow$ Ease of payment & 0.685 & 9.86 & 0.689 & 11.19 & Not supported \\
\hline H6j & E-servicescape $\rightarrow$ Perceived security & 0.752 & 12.72 & 0.677 & 11.60 & Supported \\
\hline $\mathrm{H} 7$ & E-servicescape $\rightarrow$ Trust & 0.908 & 15.58 & 0.936 & 16.68 & Not supported \\
\hline H8 & Trust $\rightarrow$ E-WOM intentions & 0.501 & 8.10 & 0.315 & 5.35 & Supported \\
\hline H9 & Trust $\rightarrow$ Customer loyalty & 0.728 & 11.31 & 0.671 & 10.95 & Supported \\
\hline
\end{tabular}




\section{CHAPTER 5}

\section{DISCUSSION AND IMPLICATIONS}

\section{Discussion}

The present research was aimed at addressing three main research questions pertaining to e-servicescape, trust, E-WOM, customer loyalty, and purchase intentions. More specifically, three goals were pursued. First, the role of customer reviews in e-servicescape was investigated. Second, the relationships between e-servicescape and trust, trust and E-WOM, and trust and customer loyalty were examined in an integrated research model. Third and finally, two types of electronic communication methods, i.e., emails and social network postings, were compared to better understand the relationships between the constructs of interest.

To answer the first question, customer reviews, as a sub-dimension in the layout and functionality dimension, was significantly related to e-servicescape. While the path estimate for customer reviews in relation to e-servicescape was lower than other sub-dimensions, this finding is still important. The low path estimate may be an artifact of the research design, with a particular e-tailer in a specific product category. Also, the target market for the e-tailer consists of Baby Boomers, which may diminish the value of customer reviews in their online purchase decisions involving apparel and accessories.

The second research objective was to test an integrated research model with eservicescape, trust, E-WOM intentions, and purchase intentions. The results of this study supported the comprehensive model tested. E-servicescape was positively related to trust, which is consistent with previous research (Harris and Goode 2010; Tran, Strutton, and Taylor 2012). In addition, trust was positively associated with both E-WOM and customer loyalty. Another 
part of the research model showed trust influencing E-WOM behavioral intentions. The findings of this study support this relationship.

Moreover, there is a difference in customers' perceptions when it comes to emails versus social network postings from the same e-tailer. For two groups of customers (email recipients and social network posting recipients), the overall research model was compared. Email recipients perceive the relevant online servicescape as more visually appealing, entertaining, and secure. In addition, customers receiving emails also valued customer reviews and found the information to be more relevant. Recipients of social network postings had higher perceptions of interactivity, ease of payment features, and trust in the e-tailer. Finally, the email receivers showed more customer loyalty and E-WOM behavioral intentions. The results of this research hold theoretical and managerial implications, which will be examined in the following sections of this chapter.

\section{Theoretical Contributions}

The present study adds to the understanding of online consumer behavior in the marketing literature by filling a gap that has not been previously investigated. This research applies stimulus-organism-response (SOR) Theory from environmental psychology to consumer research and empirically tests its application in the specific case of online servicescape as the stimulus. Moreover, the network co-production model (NCPM) of E-WOM is also part of the theoretical foundation for this research study. The study empirically tested an integrated model based on SOR theory and the NCPM in the context of consumer behavior online to enrich its foundations and identify how e-servicescape influences consumers' trust, E-WOM intentions, and customer loyalty. 
With the e-servicescape of a website identified as the stimulus and the consumer's internal reaction of trust identified as the organism of the SOR model, the study's findings provide support for SOR theory. The response is the behavioral action of approaching or avoiding the stimulus. In the present research, two specific responses of E-WOM and customer loyalty were investigated. In support of SOR theory, the findings indicate that SOR theory is an appropriate theoretical foundation for understanding two approach behaviors for online shoppers, E-WOM intentions, and customer loyalty.

Trust has been recognized as a key mediator in the relationship between website quality (Everard and Galleta 2006), website design (Kim, Jin, and Swinney 2009), and e-servicescape (Harris and Goode 2010) with purchase intentions and customer loyalty (Ribbink et al. 2004; Srinivasan, Anderson, and Ponnavolu 2002). The findings provide additional support for trust as a mediator variable, which explains the associated behaviors of E-WOM intentions and customer loyalty.

Moreover, the research findings provide a better understanding of the potential multidirectional flow of information. In the network co-production model (NCPM) of E-WOM, Kozinets et al. (2010) illustrate how a marketer's seeded message is sent directly to the first consumer, and he or she then embeds meaning into the message and forwards the communication to other consumers. The other consumers may respond directly to the shared EWOM communication, and this is one way in which the multi-directional flow of information may happen. Another possibility for the multi-directional flow of information includes customer reviews. The online reviews are provided by other consumers, who originally read marketergenerated information in the process of making their purchase decisions. In this study, the multidirectional flow of E-WOM information shown in the NCPM is captured with the customer 
reviews as a sub-dimension of online servicescape. The results suggest that customer reviews are significant in users’ perceptions of e-tailers’ websites.

\section{Managerial Contributions}

As competition for online businesses continues to grow, e-tailers must consider how to use their resources effectively. These resources may be used to add additional features to boost website design, improve website quality to enhance the customer experience, and promote the offerings in efforts to acquire new customers and engage existing customers. This research involved applying theories to managerially-important questions to investigate online consumers’ perceptions of e-servicescape, trust, E-WOM intentions, and customer loyalty, with both rigor and relevance, using customer data for a single e-tailer. Previously, research on consumers’ website perceptions relied on consumers selecting their favorite website and responding to general survey questions and statements. The results of this research yield interesting insights for marketing practitioners.

The study’s findings suggest that the online servicescape of an e-tailer has much power in determining consumers' level of trust in the e-tailer. Toward the goal of maximizing trust, organizations should carefully design elements of their websites to convey trustworthiness, dependability, and credibility. Online purchases are generally associated with higher levels of perceived risk (Urban, Sultan, and Qualls 2000), which makes trust-building a crucial part of the online transaction process. Other researchers have also found that users' perceptions of website design and quality are associated with trust (Everard and Galleta 2006; Kim, Jin, and Swinney 2009). Trust is a potential deal-breaker for converting online browsers to online purchasers, and companies must pay attention to factors of their website that highly influence consumers' trust 
(Harris and Goode 2004; Jarvenpaa, Tractinsky, and Saarinen 1999; Pavlou 2003). Engendering online trust involves decreasing consumers' perceptions of risk as it pertains to the website quality and attributes (Forsythe and Shi 2003).

Previously, the conceptualization of e-servicescape did not include customer reviews. As consumers' expectations of websites continue to grow, customer reviews are a crucial element of the environmental factors of an e-tailer's website. For shoppers of exclusively e-commerce businesses, the problem of not being able to touch, smell, or try on the merchandise is particularly tricky in the decision-making process. Offering customer reviews helps e-tailers overcome these disadvantages. This consumer-created information influences online sales (Chen and Xie 2005), with 78\% of American consumers agreeing that online reviews impact their purchase decisions (Purchase Decisions 2013).

The findings support customer reviews as a sub-dimension of e-servicescape. This discovery provides statistically rigorous evidence that customer reviews is an essential part of online servicescape. This finding adds to the body of knowledge on e-servicescape and online consumer behavior. In addition, the present research addresses the call by Duan, $\mathrm{Gu}$, and Whinston (2008) for investigating consumer purchase behavior under the influence of E-WOM, with online customer reviews serving as the E-WOM in this study. E-businesses should focus on providing valuable information through online reviews to help customers make their purchase decisions. Customer reviews play an increasingly important role in the overall e-servicescape of an e-commerce business and the present research provides empirical support for adding customer reviews to the online servicescape concept.

Another practical contribution of the current study is the inclusion of E-WOM intentions and customer loyalty as potential behavioral outcomes of trust. The findings suggest that 
customer loyalty follows trust in the e-tailer. When shoppers show commitment towards the online retailer, which is demonstrated in more positive attitudes toward the business and increased intentions to make repeat purchases (Srinivasan, Anderson, and Ponnavolu 2002), they willingly pay higher prices rather than search for price deals. Consumers' level of trust in online retailers directly affects customer loyalty (Kim, Jin, and Swinney 2009; Ribbink et al. 2004). This result suggests firms should focus on elements of e-servicescape that influence trust, which in turn affects customer loyalty. This helps e-tailers retain current customers, which is less costly than acquiring new ones (Hayes 2008).

In addition to customer loyalty, trust is also associated with E-WOM intentions. For the purposes of this study, E-WOM included specifically emails and social network postings via Facebook. The findings suggest trust impacts consumers’ propensity to share forward or share the e-tailer's email or Facebook posting with friends, family, and co-workers. Since greater trust in the e-tailer is related to increased E-WOM behavioral intentions, companies should highlight their trustworthy qualities through website cues and communications to increase customers' trust and potentially stimulate E-WOM activity.

Additionally, the present research also compared two groups using the integrated research model. Consumers receiving emails were compared and contrasted with social network postings recipients for the same online retailer. Initially, it was hypothesized that the email recipient group would have higher perceptions of e-servicescape and trust, as well as greater E-WOM intentions and customer loyalty. Interestingly, the results suggested that social network postings receivers had higher perceptions of certain sub-dimensions of online servicescape, namely interactivity and ease of payment. For the interactivity sub-dimension, it is likely that consumers frequently check their social network profile and see friends’ postings, as well as companies’ postings. With 
the ubiquitous nature of smart phones, mobile devices, and W-Fi connectivity, users are looking at social media websites more often. These frequent checks may cue consumers into e-tailers' postings on Facebook, and add to the perception of general interactivity level of the website.

Regarding the ease of payment sub-dimension, it is possible that social networking site users may be more likely to keep information conveniently saved using a customer profile on the e-tailer's website. The saved information makes subsequent purchases faster, easier, and more convenient for customers. The customer profile option is available to both email and social networking site customers. However, it is this researcher's speculation that a social networking user would be more confident and more likely to use the customer profile option. Thus, their perceptions of ease of payment would be higher, when compared to email receivers.

Compared to email recipients, social network postings receivers showed greater levels of trust. This is an interesting insight, given the previous discussion of the ease of payment subdimension. This finding is counter-intuitive to how email receivers have more E-WOM intentions and customer loyalty than social network postings recipients. Engendering trust is critical in the relationship between online servicescape and customer loyalty. E-tailers must emphasize website attributes to influence consumers' trust. However, perhaps trust is not as much of a deal-breaker for social networking site users as email users.

Given the many ways companies may communicate with consumers, these revelations provide firms with additional knowledge about how each method of electronic communication may affect customers’ perceptions of online servicescape, trust, E-WOM intentions, and customer loyalty. Before abandoning emails to customers and jumping on the next bandwagon of electronic communication method, e-tailers should consider using each form of communication as a way of targeting consumers. In particular, seeding strategies may focus on well-connected 
consumers within the social networks (Hinz et al. 2011). Organizations should implement programs to better understand different forms of social networking to enhance their seeding strategies in order to maximize E-WOM. For email receivers, e-commerce businesses may focus on the interactive nature of the website and highlight interaction opportunities in email messages. The emails may utilize technology to provide video of merchandise, inform users of contests requesting customer participation, and remind customers of interactive website tools, which potentially contribute to higher levels of perceived interactivity. Furthermore, e-tailers may emphasize the convenience of saving customer profile information for email recipients by making it easier and reminding users of the websites' simple payment process.

Overall, it is crucial for e-tailers to comprehend the close relationships of the dimensions and sub-dimensions of e-servicescape in the development of trust, E-WOM intentions, and customer loyalty. When consumers interact with companies' websites, they perceive that they are interacting with the company through the technological interface. They are assessing the etailers’ performance during various factors of service delivery, which influences their trust. Consumers' level of trust potentially leads to customer loyalty and E-WOM behavior. The results of the present research can assist e-commerce businesses in understanding the role of specific dimensions and sub-dimensions of e-servicescape, as well as trust, in developing customer loyalty. Online companies can use the findings to help them in improving their websites, which can lead to building trust and enhanced customer relationships. In addition, companies may want to consider e-servicescape and trust when creating messages in efforts to engender E-WOM behavior from consumers. 


\section{Limitations and Future Research}

Despite the theoretical and managerial contributions, the present research is subject to limitations. The data collection and analysis is, by design, restricted to customers of a single etailer. This group consisted of a self-selected set of consumers. With this limited sample, there are issues with representativeness and generalizability. Furthermore, the e-tailer of focus in this study offers only apparel and accessories, which are two very specific product categories. Again, this limits generalizability to some degree. While the results are relatively generalizable, it would be prudent to replicate and extend this study to additional e-businesses in other industries.

With an eye toward enhancing understanding of e-servicescape, trust, viral marketing, and customer loyalty, future research should examine additional factors of online servicescape, such as sound and possibly texture. Technology continues to improve, which means e-tailers have opportunities to enrich their websites and offer more information for consumers to make their purchase decisions. E-servicescape does not currently account for video clips describing products, product demonstrations, or potential uses for products. Depending on the product category, adding a sub-dimension about video clips to e-servicescape may help online retailers understand if this feature is useful for consumers. Also, the sub-dimension of customer reviews was measured with only two items which resulted in interval data. To build a true scale and assess reliability, future research should include three or more measures.

Another extension of this research would be to investigate this same integrated model in the business-to-business context. Many purchase decisions happen within industrial organizations, and collecting data from organizational buyers may be a fruitful avenue for research to better understand how online servicescape impacts trust, as well as firm-to-firm 
loyalty. It would also be interesting to compare organizational buyers to end-use consumers using the research model.

Another potential avenue of research would be to gather data on customers' actual purchases and E-WOM behavior and integrate this into the research design. It would be interesting to explore this type of customer data and compare it to behavioral intentions.

Additionally, this study did not consider message design, content, or frequency, which would potentially result in stimulating insights. 


\section{REFERENCES}

Altoft, Patrick (2008, June 12), “The Top 10 Viral Marketing Campaigns of All Time,” (accessed April 16, 2014) [available at http://www.branded3.com/blogs/the-top-10-viralmarketing-campaigns-of-all-time/].

Anderson, Myles (2013, June 26), “2013 Study: 79\% of Consumers Trust Online Reviews as Much as Personal Recommendations,” (accessed May 28, 2014) [available at http://searchengineland.com/2013-study-79-of-consumers-trust-online-reviews-as-much-aspersonal-recommendations-164565].

Anderson, Rolph E. and Srini S. Srinivasan (2003), “E-Satisfaction and E-Loyalty: A Contingency Framework,” Psychology \& Marketing, 20 (2), 123-38.

Angel, Robert and Joseph Sexsmith (2011), "Social Networking: The Corporate Value Proposition," Ivey Business Journal, 73 (4).

Armstrong, J. Scott and Terry S. Overton (1977), "Estimating Nonresponse Bias in Mail Surveys,” Journal of Marketing Research, 14 (3), 396-402.

Arndt, Johan (1967), "Role of Product-Related Conversations in the Diffusion of New Product," Journal of Marketing Research, 4 (3), 291-95.

Bagozzi, Richard P. (1975), “Marketing as Exchange,” Journal of Marketing, 39 (4), 32-39.

---- and Youjae Yi (1988), “On the Evaluation of Structural Equation Models,” Journal of the Academy of Marketing Science, 14 (May), 209-26.

Baker, Julie, Dhruv Grewal, and Ananthanarayanan Parasuraman (1994), "The Influence of Store Environment on Quality Inferences and Store Image," Journal of the Academy of Marketing Science, 22 (4), 328-39.

----, Leonard L. Berry, and Albert Parasuraman (1988), “The Marketing Impact of Branch Facility Design,” Journal of Retail Banking, 10 (2), 33-42.

Balter, Dave (2005), Grapevine: Why Buzz was a Fad But Word of Mouth is Forever. New York, NY: Penguin Group.

Bansal, Harvir S. and Peter A. Voyer (2000), "Word-of-Mouth Processes within a Services Purchase Decision Context,” Journal of Services Research, 13 (3), 166-77.

Bauer, Hans H., Mark Grether, and Mark Leach (2002), "Building Customer Relations Over the Internet,” Industrial Marketing Management, 31 (2), 155-63.

Bayus, Barry L. (1985), "Word of Mouth: The Indirect Effects of Marketing Efforts,” Journal of Advertising Research, 25 (3), 31-39. 
Beatty, Sharon E., Morris Mayer, James E. Coleman, Kristy Ellis Reynolds, and Jungki Lee (1996), “Customer-Sales Associates Relationships,” Journal of Retailing, 72 (3), 223-47.

Berger, Jonah, Alan T. Sorensen, and Scott J. Rasmussen (2012), "Positive Effects of Negative Publicity: When Negative Reviews Increase Sales,” Marketing Science, 29 (5), 815-27.

Berger, Peter L. and Thomas Luckmann (1966), The Social Construction of Reality. New York, NY: Anchor.

Bickart, Barbara and Robert M. Schindler (2001), "Internet Forum as Influential Sources of Consumer Information,” Journal of Interactive Marketing, 15 (3), 31-40.

Bitner, Mary Jo (1990), "Evaluating Service Encounters: The Effects of Physical Surroundings and Employee Responses,” Journal of Marketing, 54, 69-82.

---- (1992), "Servicescapes: The Impact of Physical Surroundings on Customers and Employees,” Journal of Marketing, 56 (2), 57-71.

Booms, Bernard H. and Mary Jo Bitner (1982), "Marketing Services by Managing the Environment,” Cornell Hotel and Restaurant Administration Quarterly, 23 (May), 35-39.

Borgida, Eugene and Richard E. Nisbett (1977), “The Differential Effect of Abstract vs. Concrete Information on Decisions,” Journal of Applied Social Psychology, 7 (July/August), 258-71.

Bowen, John T. and Stowe Shoemaker (1998), “Loyalty: A Strategic Commitment,” Cornell Hotel and Restaurant Administration Quarterly, 39 (1), 12-25.

Boyd, Danah M. and Nicole B. Ellison (2007), "Social Network Sites: Definition, History, and Scholarship,” Journal of Computer-Mediated Communication, 13 (1), 210-30.

Brooks, Robert C., Jr. (1957), “Word-of-Mouth Advertising in Selling New Products,” Journal of Marketing, 22 (2), 154-61.

Brown, Jacqueline Johnson and Peter H. Reingen (1987), "Social Ties and Word-of-Mouth Referral Behavior,” Journal of Consumer Research, 14 (3), 350-62.

Brown, Jo, Amanda J. Broderick, and Nick Lee (2007), "Word of Mouth Communication within Online Communities: Conceptualizing the Online Social Network,” Journal of Interactive Marketing, 21 (3), 2-20.

Buttle, Francis A. (1998), "Word-of-Mouth: Understanding and Managing Referral Marketing,” Journal of Strategic Marketing, 6 (3), 241-54.

Cases, Anne-Sophie, Christophe Fournier, Pierre-Louis Dubois, John F. Tanner Jr. (2010), "Web Site Spill Over to Email Campaigns: The Role of Privacy, Trust, and Shoppers’ Attitudes,” Journal of Business Research, 63 (9), 993-99. 
Cazier, Joseph A., Benjamin Shao, and Robert D. St. Louis (2006), "E-business Differentiation through Value-Based Trust," Information \& Management, 43 (6), 718-27.

Chan, Hui-Chen and Kuo-Ming Chu (2007), “The Construction Model of Customer Trust, Perceived Value and Customer Loyalty,” Review of Business Research, 7 (1), 107-12.

Charlton, Graham (2010, February 7), "Why Retailers Need to Embrace Mobile Internet in Stores,” (accessed May 28, 2014) [available at https://econsultancy.com/blog/8919-whyretailers-need-to-embrace-mobile-internet-in-stores\#i.173htg812tcd7j].

Chatterjee, Patrali (2001), “Online Reviews: Do Consumers Use Them?” Advances in Consumer Research, 28 (1), 129-33.

Chebat, Jean-Charles and Richard Michon (2003), "Impact of Ambient Odors on Mall Shoppers' Emotions, Cognition and Spending: A Test of Competitive Causal Theories,” Journal of Business Research, 56 (7), 529-39.

Chen, Su Jane and Tung Zong Chang (2003), “A Descriptive Model of Online Shopping Process: Some Empirical Results,” International Journal of Service Management, 14 (5), 556-69.

Chen, Yu-Hui and Stuart Barnes (2007), “Initial Trust and Online Buyer Behavior,” Industrial Management and Data Systems, 107 (1), 21-36.

Chen, Yubo and Jinhong Xie (2004), “Online Consumer Review: A New Element of Marketing Communications Mix,” Working Paper, University of Arizona.

---- and Jinhong Xie (2005), “Third-Party Product Review and Firm Marketing Strategy,” Marketing Science, 24 (2), 218-40.

Chen, Yuxin and K. Sudhir (2004), "When Shopbots Meet Emails: Implications for Price Competition on the Internet,” Quantitative Marketing and Economics, 2 (3), 233-55.

Cheung, Christy and Matthew K.O. Lee (2000), "Trust in Internet Shopping: A Proposed Model and Measurement Instrument," in AMCIS 2000 Proceedings, Paper 406.

----, Matthew K.O. Lee, and Neil Rabjohn (2008), “The Impact of Electronic Word-of-mouth: The Adoption of Online Opinions in Online Customer Communities,” Internet Research, 18 (3), 229-47.

Chevalier, Judith A. and Dina Mayzlin (2006), "The Effect of Word of Mouth on Sales: Online Book Reviews,” Journal of Marketing Research, 43 (3), 345-54.

Childers, Terry L. (1986), “Assessment of the Psychometric Properties of an Opinion Leadership Scale,” Journal of Marketing Research, 23 (2), 184-88.

Chiu, Hung-Chang, Yi-Ching Hsieh, Ya-Hui Kao, and Monle Lee (2007), "The Determinants of Email Receivers' Disseminating Behaviors on the Internet,” Journal of Advertising Research, 47 (4), 524-34. 
Chu, Shu-Chuan and Yoojung Kim (2011), "Determinants of Consumer Engagement in Electronic Word-of-Mouth (eWOM) in Social Networking Sites,” International Journal of Advertising, 30 (1), 47-75.

Chung, Cindy M. Y. and Peter R. Darke (2006), "The Consumer as Advocate: Self-relevance, Culture, and Word-of-Mouth,” Marketing Letters, 17, 269-79.

Churchill, Gilbert A., Jr. (1979), “A Paradigm for Developing Better Measures of Marketing Constructs,” Journal of Marketing Research, 16 (1), 64-73.

“Consumer Electronics Buyers Rely More on Consumer Reviews than Professional Reviews," (2013, January 7) (accessed April 21, 2014) [available at http://www.marketingcharts.com/wp/online/consumer-electronics-buyers-rely-more-onconsumer-reviews-than-professional-reviews-25975/].

Corbitt, Brian J., Theerasak Thanasankit, and Han Yi (2003), “Trust and E-Commerce: A Study of Consumer Perceptions,” Electronic Commerce Research and Applications, 2 (3), 203-15.

Cova, Bernard and Veronique Cova (2002), "Tribal Marketing: The Tribalisation of Society and Its Impact of the Conduct of Marketing,” European Journal of Marketing, 36 (5/6), 595-620.

Czepiel, John A. (1974), "Word-of-Mouth Processes in the Diffusion of a Major Technological Innovation,” Journal of Marketing Research, 11 (2), 172-80.

Davis, Alanah and Deepak Khazanchi (2008), "An Empirical Study of Online Word of Mouth as a Predictor for Multi-Product Category e-Commerce Sales,” Electronic Markets, 18 (2), 130-41.

Davis, Tim R.V. (1984), “The Influence of the Physical Environment in Offices,” Academy of Management Review, 9 (2), 271-83.

Day, George S. (1971), “Attitude Change, Media, and Word of Mouth,” Journal of Advertising Research, 11 (6), 31-40.

De Bruyn, Arnaud and Gary L. Lilien (2008), "A Multi-Stage Model of Word-of-Mouth Influence through Viral Marketing," International Journal of Research in Marketing, 25 (3), 151-63.

Delgado-Ballester, Elena and Jose Luis Munuera-Aleman (2001), "Brand Trust in the Context of Consumer Loyalty," European Journal of Marketing, 35 (11/12), 1238-58.

Dellarocas, Chrysanthos (2003), "The Digitization of Word of Mouth: Promise and Challenges of Online Feedback Mechanisms,” Management Science, 49 (10), 1401-24.

“Deloitte’s 2010 Annual Holiday Survey: The Season for Reason,” (2010, October), (accessed May 23, 2014) [available at http://www.deloitte.com/assets/DcomSouthAfrica/Local\%20Assets/Documents/Year\%20End\%20Holiday\%20Survey\%202010.pdf]. 
“Deloitte’s 2012 Annual Holiday Survey: Will Retailers’ Registers Jingle this Holiday Season?” (2012, October), (accessed May 23, 2014) [available at https://www.deloitte.com/assets/DcomUnitedStates/Local\%20Assets/Documents/RetailDistribution/us_retail_2012-Annual-HolidaySurvey_102412.pdf].

“Deloitte's 2013 Annual Holiday Survey: Naughty or Nice? How Will Retail Sales Fare this Holiday Season?” (2013, October), (accessed May 23, 2014) [available at http://www.deloitte.com/assets/DcomUnitedStates/Local\%20Assets/Documents/us_Retail_2013HolidaySurveyResults_102113.pdf].

Di Ianni, Alfonso (2000), “The E-business Enterprise and the 'Web-first' Principle of Emarketing,” Journal of Interactive Marketing, 2 (2), 158-70.

Dichter, Ernest (1966), "How Word-of-Mouth Advertising Works," Harvard Business Review, 44 (6), 291-304.

Doney, Patricia M. and Joseph P. Cannon (1997), "An Examination of the Nature of Trust in Buyer-Seller Relationships," Journal of Marketing, 61 (April), 35-51.

Donnelly, Vanessa (2000), Designing Easy-to-Use Websites. Harlow, England: Pearson Education Unlimited.

Donovan, Robert J. and John R. Rossiter (1982), “Store Atmosphere: An Environmental Psychology Approach,” Journal of Retailing, 58 (Spring), 34-57.

----, John R. Rossiter, Gilian Marcoolyn, and Andrew Nesdale (1994), "Store Atmosphere and Purchasing Behavior,” Journal of Retailing, 70 (3), 283-94.

Duan, Wenjing, Bin Gu, and Andrew B. Whinston (2008), "Do Online Reviews Matter? An Empirical Investigation of Panel Data," Decision Support Systems, 45 (4), 1007-16.

Durkheim, Emilie (1912), The Elementary Forms of Religious Life. New York, NY: Free Press.

Edvardsson, Bo, Bo Enquist, and Robert Johnston (2010), "Design Dimensions of Experience Rooms for Service Test Drives: Case Studies in Several Service Contexts," Managing Service Quality, 20 (4), 312-27.

Engel, James F., Robert J. Kegerreis, and Roger D. Blackwell (1969), "Word-of-Mouth Communication by the Innovator," Journal of Marketing, 33 (July), 15-19.

----, Roger D. Blackwell, and Paul W. Miniard (1990), Consumer Behavior, $6^{\text {th }}$ edition. Chicago, IL: Dryden.

Eroglu, Sevgin A., Karen Machleit, and Lenita M. Davis (2001), “Atmospheric Qualities of Online Retailing: A Conceptual Model and Implications,” Journal of Business Research, 54 (2), 177-84. 
----, Karen Machleit, and Lenita M. Davis (2003), "Empirical Testing of a Model of Online Store Atmospherics and Shopper Responses,” Psychology \& Marketing, 20 (2), 139-50.

----, Karen Machleit, and Terri Feldman Barr (2005), "Perceived Retail Crowding and Shopping Satisfaction: The Role of Shopping Values,” Journal of Business Research, 58 (8), 1146-53.

Evans, Joel R. and Vanessa E. King (1999), "Business-to-Business Marketing and the World Wide Web: Planning, Managing, and Assessing Web Sites,” Industrial Marketing Management, 28 (4), 343-58.

Everard, Andrea and Dennis F. Galletta (2006), "How Presentation Flaws Affect Perceived Site Quality, Trust, and Intention to Purchase from an Online Store,” Journal of Management Information Systems, 22 (3), 55-95.

Feick, Lawrence F. and Linda L. Price (1987), “The Market Maven: A Diffuser of Marketplace Information,” Journal of Marketing, 51 (1), 83-97.

Ferguson, Rick (2008), "Word of Mouth and Viral Marketing: Taking the Temperature of the Hottest Trends in Marketing," Journal of Consumer Marketing, 25 (3), 179-82.

Fiore, Ann Marie and Hyun-Jeong Jin (2003), “Influence of Image Interactivity on Approach Responses towards an Online Retailer,” Internet Research, 13 (1), 38-48.

---- and Jihyun Kim (2007), “An Integrative Framework Capturing Experiential and Utilitarian Shopping Experience,” International Journal of Retail and Distribution Management, 35 (6), 421-42.

----, Xinlu Yah, and Eunah Yoh (2000), “Effects of a Product Display and Environmental Fragrancing on Approach Responses and Pleasurable Experience,” Psychology \& Marketing, 17 (1), 27-54.

Flavián, Carlos, and Miguel Guinalíu (2006), "Consumer Trust, Perceived Security and Privacy Policy: Three Basic Elements of Loyalty to a Web Site," Industrial Management \& Data Systems, 106 (5), 601-20.

Fornell, Claes and David F. Larcker (1981), "Evaluating Structural Equation Models with Unobservable Variables and Measurement Error,” Journal of Marketing Research, 18 (1), 39-50.

Forsythe, Sandra M. and Bo Shi (2003), “Consumer Patronage and Risk Perceptions in Internet Shopping,” Journal of Business Research, 56 (11), 867-75.

Frels, Judy and P.K. Kannan (2001), “Consumers Risk Perceptions in Conducting Online Transactions,” Working Paper, University of Maryland, College Park.

Gatignon, Hubert and Thomas S. Robertson (1986), “An Exchange Theory Model of Interpersonal Communication,” in Advances in Consumer Research, Vol. 13, Richard J. Lutz, ed. Provo, UT: Association for Consumer Research, 534-38. 
Gefen, David and Detmar W. Straub (2004), "Consumer Trust in B2C e-Commerce and the Importance of Social Presence: Experiments in e-Products and e-Services,” The International Journal of Management Science, 32 (6), 407-24.

----, Elena Karahanna, and Detmar W. Straub (2003), “Trust and TAM in Online Shopping: An Integrated Model,” MIS Quarterly, 27 (1), 51-90.

Gehrke, Dave and Efraim Turban (1999), "Determinants of Successful Website Design: Relative Importance and Recommendations for Effectiveness,” paper presented at the $32^{\text {nd }}$ Hawaii International Conference on System Sciences (January).

Gerbing, David W. and James C. Anderson (1988), “An Updated Paradigm for Scale Development Incorporating Unidimensionality and Its Assessment,” Journal of Marketing Research, 25 (2), 186-92.

Gilly, Mary C., John L. Graham, Mary Finley Wolfinbarger, and Laura J. Yale (1998), “A Dyadic Study of Interpersonal Information Search,” Journal of the Academy of Marketing Science, 26 (2), 83-100.

Godes, David and Dina Mayzlin (2004), "Using Online Conversations to Study Word-of-Mouth Communication,” Marketing Science, 23 (4), 545-60.

Godin, Seth (1999), Permission Marketing: Turning Strangers into Friends, and Friends into Customers. New York, NY: Simon and Schuster.

Goldenberg, Jacob, Barak Libai, and Eitan Muller (2001), “Talk of the Network: A Complex Systems Look at the Underlying Process of Word-of-Mouth,” Marketing Letters, 12 (3), 53-72.

Gopal, Ram D., Arvind K. Tripathi, and Zhiping D. Walter (2006), "Economics of First-Contact Email Advertising,” Decision Support Systems, 42 (3), 1366-82.

Gounaris, Spiros P. (2005), "Trust and Commitment Influences on Customer Retention: Insights from Business-to-Business Services," Journal of Business Research, 58 (2), 126-40.

Grabner-Kräuter, Sonja, and Ewald A. Kaluscha (2003), "Empirical Research in Online Trust: A Review and Critical Assessment," International Journal of Human-Computer Studies, 58 (6), 783-812.

Grewal, Dhruv, Joan Lindsey Mullikin, and Jeanne Munger (2003), “Loyalty in E-Tailing: A Conceptual Framework,” Journal of Relationship Marketing, 2 (3/4), 31-45.

Griffin, Charlie (2007, August 14), "Website Relevance: What the Search Engines are Really Ranking On,” (accessed May 16, 2014) [available at http://voices.yahoo.com/website-relevancesearch-engines-really-488578.html].

Groeppel-Klein, Andrea and Benedikt Bartmann (2008), "Anti-Clockwise or Clockwise? The Impact of Store Layout on the Process of Orientation in a Discount Store," European Advances in Consumer Research, 8, 415-16. 
Ha, Young and Sharron J. Lennon (2010), "Online Visual Merchandising (VMD) Cues and Consumer Pleasure and Arousal: Purchasing versus Browsing Situation,” Psychology \& Marketing, 27 (2), 141-65.

Hair, Joseph F., William C. Black, Barry J. Babin, Rolph E. Anderson, and Ronald L. Tatham (2006), Multivariate Analysis, $6^{\text {th }}$ ed. Upper Saddle River, NJ: Pearson Education, Inc.

Han, Ke-Tsung (2007), "Responses to Six Major Terrestrial Biomes in Terms of Scenic Beauty, Preference and Restorativeness,” Environment \& Behavior, 39 (4), 529-56.

Harrell, Gilbert D., Michael D. Hutt, and James C. Anderson (1980), "Path Analysis of Buyer Behavior under Conditions of Crowding,” Journal of Marketing Research, 17 (1), 45-51.

Harris, James R. (1990), "Ethical Values of Individuals at Different Levels in the Organizational Hierarchy of a Single Firm,” Journal of Business Ethics, 9 (9), 741-50.

Harris, Lloyd C. and Mark M.H. Goode (2004), “The Four Levels of Loyalty and the Pivotal Role of Trust: A Study of Online Loyalty, Trust, Satisfaction, Value, and Service Quality,” Journal of Retailing, 80 (2), 139-58.

---- and Mark M.H. Goode (2010), “Online Servicescapes, Trust, and Purchase Intentions,” Journal of Services Marketing, 24 (3), 230-43.

Hartnett, Michael (2000), “New Features Take Do-It-Best Website to Higher Level,” Stores, 82 (2), 50-54.

Hayes, Bob E. (2008), “The True Test of Loyalty,” Quality Progress, 41 (6), 20-26.

Haywood, K. Michael (1989), “Managing Word of Mouth Communications,” Journal of Services Marketing, 3 (2), 55-67.

Henderson, Samantha and Michael Gilding (2004), "'I’ve Never Clicked this Much with Anyone in My Life': Trust and Hyperpersonal Communication in Online Friendships," New Media \& Society, 6 (4), 487-506.

Hennig-Thurau, Thorsten and Gianfranco Walsh (2004), "Electronic Word of Mouth: Motives for and Consequences of Reading Customer Articulations on the Internet," International Journal of Electronic Commerce, 8 (2), 51-74.

----, Kevin P. Gwinner, Gianfranco Walsh, and Dwayne D. Gremler (2004), "Electronic Wordof-Mouth via Consumer-Opinion Platforms: What Motivates Consumers to Articulate Themselves on the Internet?" Journal of Interactive Marketing, 18 (1), 38-52.

Herr, Paul, Frank R. Kardes, and John Kim (1991), "Effects of Word-of-Mouth and ProductAttribute Information on Persuasion: An Accessibility-Diagnosticity Perspective,” Journal of Consumer Research, 17 (4), 454-62. 
Hinz, Oliver, Bernd Skiera, Christian Barrot, and Jan U. Becker (2011), “Seeding Strategies for Viral Marketing: An Empirical Comparison,” Journal of Marketing, 75 (6), 55-71.

Ho, Jason Y. C. and Melanie Dempsey (2010), "Viral Marketing: Motivations to Forward Online Content,” Journal of Business Research, 63 (9), 1000-06.

Hoffman, Donna L., Thomas P. Novak, and Marcos Peralta (1999), "Building Consumer Trust Online," Communications of the ACM, 42 (4), 80-85.

Hoque, Abeer Y. and Gerald L. Lohse (1999), “An Information Search Cost Perspective for Designing Interfaces for Electronic Commerce,” Journal of Marketing Research, 36 (3), 387-94.

Hu, Li-Tze and Peter M. Bentler (1999), "Cutoff Criteria for Fit Indexes in Covariance Structure Analysis: Conventional Criteria versus New Alternatives,” Structural Equation Modeling, 6 (1), $1-55$.

Huang, Chien-Chih, Tung-Ching Lin, and Kuei-Ju Lin (2009), "Factors Affecting Pass-along Email Intentions (PAEIs): Integrating the Social Capital and Social Cognition Theories,” Electronic Commerce Research and Applications, 8 (3), 160-69.

Huang, Jen-Hung, Teng-Tai Hsiao and Yi-Fen Chen (2012), "The Effects of Electronic Word-ofMouth on Product Judgment and Choice: The Moderating Role of the Sense of Virtual Community,” Journal of Applied Social Psychology, 42 (9), 2326-47.

Hui, Michael K. and John E.G. Bateson (1991), "Perceived Control and the Effects of Crowding and Consumer Choice on the Service Experience,” Journal of Consumer Research, 18 (2), 17484.

Huizingh, Eelko K.R.E. (2002), “The Antecedents of Website Performance,” European Journal of Marketing, 36 (11/12), 1225-47.

Hung, Kineta H. and Stella Yiyan Li (2007), “The Influence of eWOM on Virtual Consumer Communities: Social Capital, Consumer Learning, and Behavioral Outcomes,” Journal of Advertising Research, 47 (4), 485-95.

Jackson, Anita and Ray DeCormier (1999), "E-mail Survey Response Rates: Targeting Increases Responses,” Journal of Marketing Intelligence and Planning, 17 (3), 135-40.

Jansen, Bernard J., Mimi Zhang, Kate Sobel, and Abdur Chowdhury (2009), “Twitter Power: Tweets as Electronic Word of Mouth,” Journal of the American Society for Information Science and Technology, 60 (1), 2169-88.

Jarvenpaa, Sirkka L., Kathleen Knoll, and Dorothy E. Leidner (1998), "Is Anybody Out There? Antecedents of Trust in Global Virtual Teams," Journal of Management Information Systems, 14 (4), 29-64.

----, Noam Tractinsky, and Lauri Saarinen (1999), “Consumer Trust in an Internet Store: A Cross-Cultural Validation,” Journal of Computer-Mediated Communication, 5 (2). 
----, Noam Tractinsky, and Michael Vitale (2000), “Consumer Trust in an Internet Store,” Information Technology and Management, 1 (1/2), 45-71.

John, Deborah Roedder (1999), "Consumer Socialization of Children: A Retrospective Look at Twenty-Five Years of Research,” Journal of Consumer Research, 26 (3), 183-213.

Kaikati, Andrew M. and Jack G. Kaikati (2004), "Stealth Marketing: How to Reach Consumers Surreptitiously,” California Management Review, 46 (4), 6-22.

Kaplan, Andreas M. and Michael Haenlein (2011), "Two Hearts in Three-Quarter Time: How to Waltz the Social Media/Viral Marketing Dance,” Business Horizons, 54 (3), 253-63.

Kaplan, Rachel and Stephen Kaplan (1989), The Experience of Nature: A Psychological Perspective. New York, NY: Cambridge Press.

Kaplan, Stephen (1995), “The Restorative Benefits of Nature: Toward an Integrative Framework,” Journal of Environmental Psychology, 15 (3), 169-82.

Kass, Robert E. and Adrian E. Raftery (1995), “Bayes Factors,” Journal of the American Statistical Association, 90 (430) 773-95.

Katz, Elihu and Paul F. Lazarsfeld (1955), Personal Influence: The Part Played by People in the Flow of Mass Communications. New York, NY: The Free Press.

Keiningham, Timothy L., Lerzan Aksoy, Bruce Cooil, and Tor Walin Andreassen (2008), “Linking Customer Loyalty to Growth,”MIT Sloan Management Review, 49 (4), 50-57.

Keller, Ed (2007), "Unleashing the Power of Word of Mouth: Creating Brand Advocacy to Drive Growth,” Journal of Advertising Research, 47 (4), 448-52.

Kent, Ray and Hege Brandal (2003), "Improving Email Response in a Permission Marketing Context,” International Journal of Market Research, 45 (4), 489-503.

Kim, Jai Ok and Byoungho Jin (2001), "The Mediating Role of Excitement in Consumer Satisfaction and Repatronage Intention of Discount Store Shoppers in Korea," Journal of Shopping Center Research, 8 (2), 117-38.

Kim, Jihyun, Ann Marie Fiore, and Hyun-Hwa Lee (2007), “Influences of Online Store Perception, Shopping Environment, and Shopping Involvement on Consumer Patronage Behavior towards an Online Retailer," Journal of Retailing and Consumer Services, 14 (2), 95107.

Kim, Jiyoung and Sharron J. Lennon (2013), "Effects of Reputation and Website Quality on Online Consumers' Emotion, Perceived Risk, and Purchase Intention,” Journal of Research in Interactive Marketing, 7 (1), 33-56. 
----, Byoungho Jin, and Jane L. Swinney (2009), “The Role of Etail Quality, E-satisfaction and

E-Trust in Online Loyalty Development Process,” Journal of Retailing and Consumer Sciences, 16 (4), 239-47.

Kim, Minjeong and Sharron Lennon (2008), “The Effects of Visual and Verbal Information on Attitudes and Purchase Intentions in Internet Shopping,” Psychology \& Marketing, 25 (2), 14678.

King, Charles W. and Frank O. Summers (1976), “Overlap of Opinion Leadership across Product Categories,” Journal of Marketing Research, 7 (February), 43-50.

Kozinets, Robert V., Kristine de Valck, Andrea C. Wojnicki, and Sarah J. S. Wilner (2010), "Networked Narratives: Understanding Word-of-Mouth Marketing in Online Communities," Journal of Marketing, 74 (2), 71-89.

Kumar, V., J. Andrew Petersen, and Robert P. Leone (2007), "How Valuable is Word of Mouth?” Harvard Business Review, 85 (10), 139-46.

Lee, Jonathan, Janghyuk Lee, and Lawrence Feick (2006), "Incorporating Word-of-Mouth Effects in Estimating Customer Lifetime Value,” Journal of Database Marketing and Customer Strategy Management, 14 (2), 29-39.

Lee, Kevan (2014, March 5), “Email Marketing’s 10 Most Important Questions, Answered,” (accessed April 19, 2014) [available at http://blog.bufferapp.com/email-marketing-10-mostimportant-questions-answered].

Lee, Matthew K.O. and Efraim Turban (2001), “A Trust Model for Consumer Internet Shopping,” International Journal of Electronic Commerce, 6 (1), 75-91.

Lee, Seonjeong Ally and Miyoung Jeong (2012), “Effects of E-Servicescape on Consumers' Flow Experiences,” Journal of Hospitality and Tourism Technology, 3 (1), 47-59.

Li, Hairong, Terry Daugherty, and Frank Biocca (2001), "Characteristics of Virtual Experience in Electronic Commerce: A Protocol Analysis,” Journal of Interactive Marketing, 15 (3), 13-30.

Liu, Yong (2006), "Word-of-Mouth for Movies: Its Dynamics and Impact on Box Office Revenue,” Journal of Marketing, 70 (3), 74-89.

Lin, Hsiu-Fen (2007), “The Impact of Website Quality Dimensions on Customer Satisfaction in the B2C E-Commerce Context,” Total Quality Management and Business Excellence, 18 (4), 363-78.

Lombard, Matthew and Jennifer Snyder-Duch (2001), "Interactive Advertising and Presence: A Framework,” Journal of Interactive Advertising, 1 (2), 56-65.

Lynch, Patrick D., Robert J. Kent, and Srini S. Srinivasan (2001), “The Global Internet Shopper: Evidence from Shopping Tasks in Twelve Countries,” Journal of Advertising Research, 41 (3), 15-23. 
Mahajan, Jayashree, Gilbert A. Churchill, Jr., Neil M. Ford, and Orville C. Walker, Jr. (1984), "A Comparison of the Impact of Organizational Climate on the Job Satisfaction of Manufacturers’ Agents, and Company Salespeople: An Exploratory Study,” Journal of Personal Selling \& Sales Management, 4 (1), 1-10.

Mahajan, Vijay, Eitan Muller, and Frank M. Bass (1990), "New Product Diffusion Models in Marketing: A Review and Directions for Research,” Journal of Marketing, 54 (January), 1-26.

Mandel, Naomi and Eric J. Johnson (2002), “When Web Pages Influence Choice: Effects of Visual Primes on Experts and Novices,” Journal of Consumer Research, 29 (2), 235-45.

Mangold, W. Glynn and David J. Faulds (2009), "Social Media: The New Hybrid Element of the Promotion Mix," Business Horizons, 52 (4), 357-65.

Markey, Robert and Christopher Hopton (2000), "E-Customer Loyalty-Applying the Traditional Rules of Business for Online Success,” European Business Journal, 12 (4), 173-79.

Martin, Mary C. and James W. Gentry (1997), "Stuck in the Model Trap: The Effects of Beautiful Models in Ads on Female Pre-Adolescents and Adolescents," Journal of Advertising, 26 (Summer), 19-33.

Mattila, Anna S, and Jochen Wirtz (2001), "Congruency of Scent and Music as a Driver of InStore Evaluations and Behavior,” Journal of Retailing, 77 (2), 273-89.

Mayer, Roger C., James H. Davis, and F. David Schoorman (1995), "An Integrative Model of Organizational Trust," Academy of Management Review, 20 (3), 709-34.

McCole, Patrick (2002), "The Role of Trust for Electronic Commerce in Services," International Journal of Contemporary Hospitality Management, 14 (2), 81-87.

----, Elaine Ramsey, and John Williams (2010), “Trust Considerations on Attitudes towards Online Purchasing: The Moderating Effect of Privacy and Security Concerns,” Journal of Business Research, 63 (9), 1018-24.

McGrath, Mary Ann, John F. Sherry, and Deborah D. Heisley (1993), “An Ethnographic Study of an Urban Periodic Marketplace: Lessons from the Midville Farmers’ Market,” Journal of Retailing, 69 (3), 280-319.

McKechnie, George E. (1974), ERI Manual: Environmental Response Inventory. Palo Alto, CA: Consulting Psychologists Press.

McKnight, D. Harrison and Norman L. Chervany (2002), "What Trust Means in E-Commerce Customer Relationships: An Interdisciplinary Conceptual Typology," International Journal of Electronic Commerce, 6, 35-60.

----, Vivek Choudhury, and Charles Kacmar (2002), “Developing and Validating Trust Measures for E-Commerce,” Information Systems Research, 13 (3), 344-59. 
Mehrabian, Albert and James A. Russell (1974), An Approach to Environmental Psychology. Cambridge, MA: The MIT Press.

Mehta, Raj and Eugene Sivadas (1995), "Comparing Response Rates and Response Content in Mail versus Electronic Mail Surveys,” Journal of the Market Research Society, 37 (4), 429-39.

Menon, Satya and Barbara Kahn (2002), "Cross-Category Effects of Induced Arousal and Pleasure on the Internet Shopping Experience,” Journal of Retailing, 78 (1), 31-40.

Meyers, Peter J. (2014), “25-Point Website Usability Checklist,” (accessed May 16, 2014) [available at http://www.usereffect.com/topic/25-point-website-usability-checklist].

Miller, Rohan and Natalie Lammas (2010), "Social Media and Its Implications for Viral Marketing," Asia Pacific Public Relations Journal, 11 (1), 1-9.

Montoya-Weiss, Mitzi M., Glenn B. Voss, and Dhruv Grewal (2003), "Determinants of Online Channel Use and Overall Satisfaction with a Relational, Multichannel Service Provider," Journal of the Academy of Marketing Science, 31 (4), 448-58.

Morgan, Robert M. and Shelby D. Hunt (1994), "The Commitment-Trust Theory of Relationship Marketing," Journal of Marketing, 58 (3), 20-38.

Morrison, Donald (1979), "Purchase Intentions and Purchase Behavior," Journal of Marketing, 43 (Spring), 65-74.

Moschis, George P. (1981), “Patterns of Consumer Learning,” Academy of Marketing Science, 9 (1/2), 110-26.

Mowen, John C., Sojin Park and Alex Zablah (2007), "Toward a Theory of Motivation and Personality with Application to Word-of-Mouth Communications,” Journal of Business Research, 60 (6). 590-96.

Mukherjee, Avinandan and Prithwiraj Nath (2007) "Role of Electronic Trust in Online Retailing: A Re-examination of the Commitment-Trust Theory," European Journal of Marketing, 41 (9/10), 1173-1202.

Mummalaneni, Venkatapparo (2005), “An Empirical Investigation of Website Characteristics, Consumer Emotional States and On-line Shopping Behavior," Journal of Business Research, 58 (4), 526-32.

Muniz, Albert M. and Thomas C. O’Guinn (2001), “Brand Community,” Journal of Consumer Research, 27 (4), 412-32.

Murray, Keith B. (1991), "A Test of Services Marketing Theory: Consumer Information Acquisition Activities,” Journal of Marketing, 55 (1), 10-25.

Netemeyer, Richard G., William O. Bearden, and Subhash Sharma (2003), Scaling Procedures: Issues and Applications. Newbury Park, CA: Sage Publications, Inc. 
Newman, Jeffrey P., Laurie Garrow, Mark Ferguson, Timothy L. Jacobs, and Hadi Purnomo (2010), “Estimation of Choice-Based Models Using Sales Data from a Single Firm,” working paper, Georgia Institute of Technology.

“Nielsen: Global Consumers’ Trust in 'Earned’ Advertising Grows in Importance,” (2012, April 10), (accessed May 31, 2014) [available at http://www.nielsen.com/us/en/pressroom/2012/nielsen-global-consumers-trust-in-earned-advertising-grows.html].

Nielsen, Jakob (2008, January 22), “Usability ROI Declining, But Still Strong,” (accessed May 16, 2014) [available at http://www.nngroup.com/articles/usability-roi-declining-but-still-strong/].

Notarantonio, Elaine M. and Charles J. Quigley Jr. (2009), “The Effectiveness of a Buzz Marketing Approach Compared to Traditional Advertising: An Exploration,” Journal of Promotion Management, 15 (4), 455-64.

Nunnally, Jum C. (1978), Psychometric Theory. New York, NY: McGraw Hill.

Nyilasy, Gergely (2004), "Word-of-Mouth Advertising: A 50-Year Review and Two Theoretical Models for an Online Chatting Context," in Convention of the Association for Education in Journalism and Mass Communication, Toronto, Canada.

Okazaki, Shintaro (2009), “The Tactical Use of Mobile Marketing: How Adolescents' Social Networking Can Best Shape Brand Extensions,” Journal of Advertising Research, 49 (1), 12-26.

Oliver, Richard L. (1997), Satisfaction: A Behavioral Perspective on the Consumer. New York, NY: McGraw Hill.

Park, C. Whan, Easwar S. Iyer, and Daniel C. Smith (1989), "The Effects of Situational Factors on In-Store Grocery Shopping Behavior: The Role of Store Environment and Time Available for Shopping," Journal of Consumer Research, 15 (4) 422-33.

Park, Cheol and Thae Min Lee (2009), “Information Direction, Website Reputation and eWOM Effect: A Moderating Role of Product Type,” Journal of Business Research, 62 (1), 61-67.

Park, Do-Hyung and Jumin Lee 2008), “eWOM Overload and its Effect on Consumer Behavioral Intention Depending on Consumer Involvement,” Electronic Commerce Research and Applications, 7 (4), 386-98.

----, Jumin Lee, and Ingoo Han (2007), “The Effect of On-Line Consumer Reviews on Consumer Purchasing Intention: The Moderating Role of Involvement,” International Journal of Electronic Commerce, 11 (4), 125-48.

Parsons, Andrew, Michael Zeisser, and Robert Waitman (1998), “Organizing Today for the Digital Marketing of Tomorrow,” Journal of Interactive Marketing, 12 (1), 31-46.

Pavlou, Paul A. (2003), “Consumer Acceptance of Electronic Commerce: Integrating Trust and Risk with the Technology Acceptance Model,” International Journal of Electronic Commerce, 7 (3), 101-34. 
---- and David W. Stewart (2000), "Measuring the Effects and Effectiveness of Interactive Advertising,” Journal of Interactive Advertising, 1 (1), 61-77.

Pavlov, Oleg V., Nigel Melville, and Robert K. Plice (2008), “Toward a Sustainable Email Marketing Infrastructure,” Journal of Business Research, 61 (11), 1191-99.

Peter, J. Paul (1981), “Construct Validity: A Review of Basic Issues and Marketing Practices,” Journal of Marketing Research, 18 (2), 133-45.

Peters, Thomas J. (1978), "Symbols, Patterns, and Settings: An Optimistic Case for Getting Things Done,” Organizational Dynamics, 7 (Autumn), 3-23.

Petrescu, Maria and Pradeep Korgaonkar (2011), "Viral Advertising: Definitional Review and Synthesis,” Journal of Internet Commerce, 10 (3), 208-26.

Phelps, Joseph E., Regina Lewis, Lynne Mobilio, David Perry, Niranjan Raman (2004), “Viral Marketing or Electronic Word-of-Mouth Advertising: Examining Consumer Responses and Motivations to Pass Along Email,” Journal of Advertising Research, 45 (4), 333-48.

Phillip, Marissa V. and Rajneesh Suri (2004), "Impact of Gender Differences on the Evaluation of Promotional Emails,” Journal of Advertising Research, 44 (4), 360-68.

Podsakoff, Philip M., Scott B. MacKenzie, Jeong-Yeon Lee, and Nathan P. Podsakoff (2003), "Common Method Biases in Behavioral Research: A Critical Review of the Literature and Recommended Remedies,” Journal of Applied Psychology, 88 (5), 879-903.

Pousttchi, Key and Dietmar G. Wiedemann (2006), “A Contribution to Theory Building for Mobile Marketing: Categorizing Mobile Marketing Campaigns through Case Study Research,” Proceedings of the International Conference on Mobile Business.

Price, Linda L. and Lawrence F. Feick (1984), “The Role of Interpersonal Sources in External Search: An Informational Perspective,” in Advances in Consumer Research, Vol. 11 (1), Thomas C. Kinnear, ed. Provo, UT, Association for Consumer Research, 250-55.

"Purchase Decisions of Close to 80 Percent of Americans are Influenced by Online Reviews,” (2013, January 7), (accessed April 19, 2014) [available at http://www.reviewtrackers.com/purchase-decisions-close-80-percent-americans-influencedonline-reviews/].

Rayport, J. (1996, December 31), “The Virus of Marketing,” (accessed April 16, 2014) [available at http://www.fastcompany.com/27701/virus-marketing].

Reichheld, Frederick F. (1996), The Loyalty Effect. Boston, MA: Harvard Business School Press. ----, Robert Markey, and Christopher Hopton (2000), “E-customer Loyalty-Applying the Traditional Rules of Business for Online Success,” European Business Journal, 12 (4), 173-79. 
Ribbink, Dina, Allard C.R. van Riel, Veronica Liljander, and Sandra Streukens (2004), “Comfort Your Online Customer: Quality, Trust and Loyalty on the Internet,” Managing Service Quality, 14 (6), 446-456.

Richard, Marie-Odile (2005), "Modeling the Impact of Internet Atmospherics on Surfer Behavior,” Journal of Business Research, 58 (12), 1632-42.

----, Jean-Charles Chebat, Zhiyong Yang, and Sanjay Putrevu (2009), “A Proposed Model of Online Consumer Behavior: Assessing the Role of Gender,” Journal of Business Research, 63 (9/10), 926-34.

Richins, Marsha L. (1983), “Negative Word-of-Mouth by Dissatisfied Customers: A Pilot Study,” Journal of Marketing, 47, 68-78.

Ridings, Catherine M., David Gefen, Bay Arinze (2002), "Some Antecedents and Effects of Trust in Virtual Communities,” Journal of Strategic Information Systems, 11 (3/4), 271-95.

Robertson, Thomas S., John R. Rossiter, and Terry C. Gleason (1979), “Children’s Receptivity to Proprietary Medicine Advertising,” Journal of Consumer Research, 6 (December), 247-55.

Roed, Jannie (2003), “Language Learner Behavior in a Virtual Environment,” Computer Assisted Language Learning, 16 (2), 155-72.

Rogers, Everett M. (1995), Diffusion of Innovations, $4^{\text {th }}$ edition. New York, NY: The Free Press.

Rosen, Emanuel (2009), The Anatomy of Buzz Revisited. New York, NY: Crown Business.

Rosenbaum, Mark S. (2005), “The Symbolic Servicescape: Your Kind is Welcomed Here,” Journal of Consumer Behavior, 4 (4), 257-67.

---- (2009), “Restorative Servicescapes: Restoring Directed Attention in Third Places,” Journal of Service Management, 20 (2), 173-91.

---- and Carolyn Massiah (2011), “An Expanded Servicescape Perspective,” Journal of Service Management, 22 (4), 471-90.

---- and Detra Y. Montoya (2007), “Am I Welcome Here? Exploring How Ethnic Consumers Assess Their Place Identity,” Journal of Business Research, 60 (3), 206-14.

Rosenspan, Alan (2000), “Permission is Not Enough,” Journal of Interactive Marketing, 2 (3), 215-18.

Schiffman, Leon G., Elaine Sherman, Mary M. Long (2003), “Toward a Better Understanding of the Interplay of Personal Values and the Internet,” Psychology \& Marketing, 20 (2), 169-86.

Schlosser, Ann E., Tiffany Barnett White, and Susan M. Lloyd (2006), “Converting Web Site Visitors into Buyers: How Web Site Investment Increases Consumer Trusting Beliefs and Online Purchase Intentions,” Journal of Marketing, 70 (April), 133-48. 
Schutz, William C. (1966), FIRO: A Three Dimensional Theory of Interpersonal Behavior. New York, NY: Holt, Rinehart, \& Winston.

Shapiro, Carl and Hal Varian (1999), Information Rules. Cambridge, MA: Harvard Business Press.

Shergill, Gurvinder S. and Zhaobin Chen (2005), “Web-Based Shopping: Consumers’ Attitudes towards Online Shopping in New Zealand,” Journal of Electronic Commerce Research, 6 (2), 79-94.

Sheth, Jagdish N. (1971), “Word-of-Mouth in Low Risk Innovations,” Journal of Advertising Research, 11 (3), 15-18.

Sherman, Elaine, Anil Mathur, and Ruth Belk Smith (1997), "Store Environment and Consumer Purchase Behavior: Mediating Role of Consumer Emotions,” Psychology \& Marketing, 14 (4), 361-78.

Shih, Chuan-Fong Eric (1998), “Conceptualizing Consumer Experiences in Cyberspace,” European Journal of Marketing, 32 (7/8), 655-663.

Shih, Hung-Pin (2004), “Extended Technology Acceptance Model of Internet Utilization Behavior,” Information \& Management Journal, 41 (6), 719-29.

Shun, Cai and Xu Yunjie (2006), "Effects of Outcome, Process, and Shopping Enjoyment on Online Consumer Behavior,” Electronic Commerce Research and Applications, 5 (4), 272-81.

Siau, Keng and Zixing Shen (2003), "Building Customer Trust in Mobile Commerce," Communications of the ACM , 46 (4), 91-94.

Silverman, George (1997), "How to Harness the Awesome Power of Word of Mouth," Direct Marketing, 60, 32-37.

"SMBmarketer.com Announces New Email Messaging Templates that Get Small Businesses Marketing Fast,” (2010, December 4), Marketing Weekly News, 1281.

Smith, Aaron (2013, June 53), “Smartphone Ownership 2013,” (accessed May 30, 2014) [available at http://www.pewinternet.org/2013/06/05/smartphone-ownership-2013/].

“Social Networking Fact Sheet," (2013, September 30), (accessed May 30, 2013) [available at http://www.pewinternet.org/fact-sheets/social-networking-fact-sheet/].

Spangenberg, Eric R., Bianca Grohmann, and David E. Sprott (2005), “It’s Beginning to Smell (and Sound) a Lot Like Christmas: The Interactive Effects of Ambient Scent and Music in a Retail Setting,” Journal of Business Research, 58 (11), 1583-89.

Spreitzer, Gretchen M. (1996), "Social Structural Characteristics of Psychological Empowerment,” Academy of Management Journal, 39 (2), 483-504. 
Srinivasan, Srini S., Rolph Anderson, and Kishore Ponnavolu (2002), "Customer Loyalty in ECommerce: An Exploration of its Antecedents and Consequences,” Journal of Retailing, 78 (1), 41-50.

Steffes, Erin M. and Lawrence E. Burgee (2009), “Social Ties and Online Word of Mouth,” Internet Research, 19 (1), 42-59.

Steyer, Alexandre, Renaud Garcia-Bardidia, and Pascale Quester (2006), “Online Discussion Groups as Social Networks: An Empirical Investigation of Word-of-Mouth on the Internet,” Journal of Interactive Advertising, 6 (2), 45-52.

Subramani, Mani R. and Balaji Rajagopalan (2003), "Knowledge-sharing and Influence in Online Social Networks via Viral Marketing,” Communications of the ACM, 46 (12), 300-07.

Sun, Tao, Seounmi Youn, Guohua Wu, and Mana Kuntarapor (2006), “Online Word-of-Mouth (or Mouse): An Exploration of Its Antecedents and Consequences,” Journal of ComputerMediated Communication, 11 (4), 1104-27.

Sundstrom, Eric and Mary Graehl Sundstrom (1986), Work Places. Cambridge, UK: Cambridge University Press.

Swanepoel, Celeste, Ashley Lye, and Robert Rugimbana (2009), "Virally Inspired: A Review of the Theory of Viral Stealth Marketing,” Australasian Marketing Journal, 17 (1), 9-15.

Szymanki, David M. and Richard T. Hise (2000), "E-Satisfaction: An Initial Examination,” Journal of Retailing, 76 (3), 309-22.

Tamir, Diana I. and Jason P. Mitchell (2012), "Disclosing Information about the Self is Intrinsically Rewarding,” Proceedings of the National Academy of Sciences, 109 (21), 8038-43.

Thamizhvanan, Arun and M.J. Xavier (2013), “Determinants of Customers’ Online Purchase Intention: An Empirical Study in India,” Journal of Indian Business Research, 5 (1), 17-32.

“The Top 15 Most Popular Social Networking Sites,” (2014, June) (accessed on June 1, 2014) [available at http://www.ebizmba.com/articles/social-networking-websites].

Thomas, Greg M. (2004), "Building the Buzz in the Hive Mind,” Journal of Consumer Behavior, 4 (1), 64-72.

Tran, Gina A., David Strutton, and David G. Taylor (2012), “Do Microblog Postings Influence Consumer Perceptions of Retailers’ E-Servicescapes?” Management Research Review, 35 (9), 818-36.

Trusov, Michael, Randolph E. Bucklin, and Koen Pauwels (2009), "Effects of Word-of-Mouth Versus Traditional Marketing: Findings from an Internet Social Networking Site,” Journal of Marketing, 73 (5), 90-102. 
Turley, Lou W. and Ronald E. Milliman (2000), “Atmospheric Effects on Shopping Behavior: A Review of the Experimental Evidence,” Journal of Business Research, 49 (2), 193-211.

ul Haq, Zia (2009), "E-mail Advertising: A Study of Consumer Attitude toward E-mail Advertising among Indian Users,” Journal of Retail \& Leisure Property, 8 (3), 207-223.

Urban, Glen L., Fareena Sultan, and William J. Qualls (2000), "Placing Trust at the Center of Your Internet Strategy,” Sloan Management Review, 42 (1), 39-48.

van der Heijden, Hans, Tibert Verhagen, and Marcel Creemers (2003), “Understanding Online Purchase Intentions: Contributions from Technology and Trust Perspectives,” European Journal of Information Systems, 12 (1), 41-48.

Vargo, Stephen L. and Robert F. Lusch (2004), "Evolving to a New Dominant Logic for Marketing,” Journal of Marketing, 68 (January), 1-17.

Veloutsou, Cleopatra, Michael Saren, and Nikoloas Tzokas (2002), “Relationship Marketing:

What If...?” European Journal of Marketing, 36 (4), 433-49.

Verhoef, Peter C., Philip Hans Franses, and Janny C. Hoekstra (2002), “The Effect of Relational Constructs on Customer Referrals and Number of Services Purchased from a Multiservice Provider: Does Age of Relationship Matter?” Journal of the Academy of Marketing Science, 30 (3), 206-16.

Ward, Scott (1974), “Consumer Socialization,” Journal of Consumer Research, 1 (2), 1-14.

----, Daniel B. Wackman, and Ellen Wartella (1977), How Children Learn to Buy. Beverly Hills, CA: Sage.

Welker, Carl B. (2002), “The Paradigm of Viral Communication,” Information Services \& Use, 22 (1), 3-8.

Westbrook, Robert A. (1987), "Product/Consumption Based Affective Responses and Postpurchase Processes,” Journal of Marketing Research, 24 (3), 258-70.

Whitman, Janet (2006), “Lessons Learned: New Dot-Coms Seek Attention Cheaply,” The Wall Street Journal, 13 February, B3A.

Whyte, William H., Jr. (1954), “The Web of Word of Mouth,” Fortune, 50 (November), 140-43.

Wilson, Edward O. (1984), Biophilia. Cambridge, MA: Harvard University Press.

Wineman, Jean D. (1982), “Office Design and Evaluation,” Environment and Behavior, 14 (3), 271-98.

Yalch, Richard and Eric Spangenberg (1990), "Effects of Store Music on Shopping Behavior,” Journal of Consumer Marketing, 7 (2), 55-63. 
"Yesmail Study: Half of Consumers Now Read Emails Only on Mobile Devices," (2014, February 25), (accessed May 23, 2014) [available at

http://www.yesmail.com/company/news/yesmail-study-half-consumers-now-read-emails-onlymobile-devices].

Yoon, Sung-Joon (2002), “The Antecedents and Consequences of Trust in Online-Purchase Decisions,” Journal of Interactive Marketing, 16 (2), 47-63.

Zeithmal, Valarie A. and Leonard L. Berry (1993), “The Nature and Determinants of Customer Expectations of Service,” Journal of the Academy Marketing Science, 21 (1), 1-12.

----, Arun Parasuraman, and Arvind Malhotra (2002), "Service Quality Delivery through Website: A Critical Review of Extant Knowledge,” Journal of the Academy of Marketing Science, 30 (4), 362-75.

----, Bitner, Mary Jo, and Dwayne D. Gremler (2009), Services Marketing: Integrating Customer Focus across the Firm. Boston, MA: McGraw-Hill/Irwin.

Zhang, Jie and Terry Daugherty (2009), “Third-Person Effect and Social Networking: Implications for Online Marketing and Word-of-Mouth Communication,” American Journal of Business, 24 (2), 53-63. 